
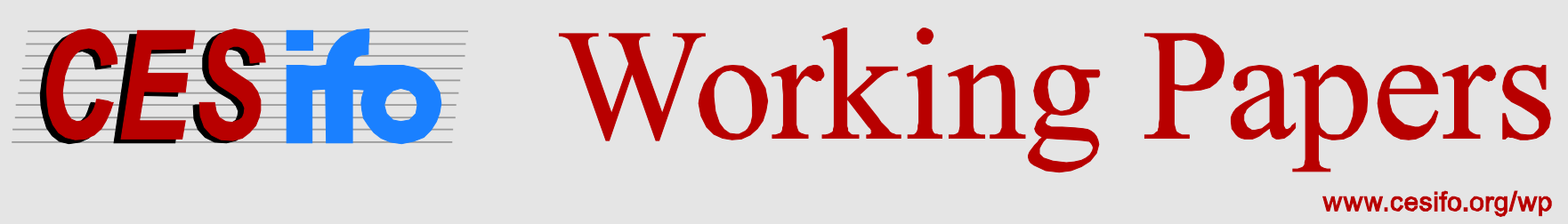

\title{
Grey Matters: Charting the Development of the Shadow Economy
}

\author{
Donal Mac Géidigh \\ Friedrich Schneider \\ Matthias Blum
}

CESIFO WORKING PAPER NO. 6234

CATEgORY 1: PUBlic FinANCE

DECEMBER 2016

An electronic version of the paper may be downloaded

- from the SSRN website: Www.SSRN.com

- from the RePEc website: Www.RePEc.org

- from the CESifo website: www.CESifo-group.org/wp 


\title{
Grey Matters: Charting the Development of the Shadow Economy
}

\begin{abstract}
The shadow economy has long been an area of research for policymakers. The determinants of underground activity of late have been identified as high tax burdens and increased regulation, but has this relationship always existed? This seminal work examines the shadow economy in Norway, Sweden, the United Kingdom and the United States over the past 145 (from 1870 to 2015) years using the Currency Demand Approach and finds that the underground economy is stabilising. To our knowledge this is the first attempt to estimate the size and development of the shadow economy over such a long period and due to this we get some new insights. Our results clearly show that the shadow economy in earlier times was considerably higher than in the last 50 years. This paper also analyses whether a plateau has been reached and questions what efforts could be made to further reduce this informal economy.
\end{abstract}

JEL-Codes: H260, K420, O170.

Keywords: shadow economy, underground activity, historical tax rates.

Donal Mac Géidigh

MSc Economics Queen's University

Belfast / United Kingdom

dmacgeidigh01@qub.ac.uk
Friedrich Schneider

Department of Economics

Johannes Kepler University

Austria - 4040 Linz-Auhof

friedrich.schneider@jku.at

Matthias Blum

Queen's Management School

Queen's University

Belfast / United Kingdom

matthias.blum@qub.ac.uk 


\section{Introduction}

The purpose of this study is to develop estimates of the size of the shadow economy in a panel of countries from 1870 to 2015 . The countries under examination are Norway, Sweden, the United Kingdom, and the United States. When developed these estimates can be added to official GDP to provide an alternative dataset of GDP figures. There does not exist so far any scientific research or research papers which try to estimate the size and development of the shadow economy over the period 1870-2015 from Norway, Sweden, the United Kingdom and the United States. Hence, our paper is a first approach to estimate the size of a shadow economy of these four countries over such a long period. It hopefully has a lot of valuable insights.

Researchers, economists, and policymakers alike could benefit from this study in numerous ways: First and foremost, shadow activity is unrecorded activity, unrecorded activity is untaxed activity meaning that state revenue is below its potential level. Secondly, the shadow economy represents a source of income and employment for individuals whose output is not included in national income account statistics. Revised GDP figures (including a shadow economy component) would provide a more accurate picture of the wealth of these four economies and their inhabitants over the last century and a half. Thirdly, Central Banks and other monetary policymakers often take their cue from economic indicators such as output, unemployment and inflation. If these indicators are inaccurate due to the presence of a large shadow economy, inappropriate policies may be adopted in response. Inaccurate macroeconomic indicators such as overestimated unemployment could lead to the implementation of expensive, inefficient social welfare programmes aimed at reducing unemployment, meaning that the plight of those who are marginalised in other areas of society may worsen.

The following section discusses developments in the world economy and political landscape over the past 150 years while also evaluating the existing literature concerning the shadow economy. Section 3 gives an overview of the methodology used to estimate the size of the shadow economy, in this case 
the Currency Demand Approach. Section 4 presents the empirical results and estimates of the shadow economy. Section 5 concludes the study with a view to further research in this area.

\section{Literature Review}

\section{"There cannot be any question that the underground economy is a real phenomenon with important implications that deserve attention and study"}

- Vito Tanzi, "Uses and Abuses of Estimates of the Underground Economy," The Economic Journal, 109 (June 1999), p. 338.

\section{$\underline{2.1 \text { General Remarks }}$}

An important component of measuring the size of the shadow economy is the development of monetary aggregates, namely $\mathrm{M} 0^{1}$ - currency in circulation, and its relationship with other measures of the money supply; M1, M2, M3 and occasionally M4. While section 3 provides a more in-depth examination of the methodology it is important to briefly lay out the intuition behind the method of measuring the shadow economy in this study: The Currency Demand Approach. ${ }^{2}$

Cash is assumed to be the fuel in the engine of shadow economic activity (Issachson and Strom, 1986). Clandestine transactions are assumed to be carried out in cash to avoid leaving a paper trail for authorities (Tanzi, 1983). Thus, an increase in the size of the shadow economy will mean that currency in circulation among the public will increase. Alanon and Gómez-Antonio (2005), Dell'Anno et al. (2007), Buehn (2012), Schneider (1986) and Schneider et al. (2010) have all concluded that the relationship between the amount of currency held by the public and the shadow economy is positive and statistically significant. Individuals obtain this extra currency by withdrawing money from their bank accounts, leading to an increase in M0 and a decrease in M1 or M2 (depending on which currency ratio is used). Of course there could be conventional factors and events that might lead to changes in the currency ratio, such as rising interest rates on deposit accounts increasing the opportunity cost of holding currency, development of income, payment habits etc. These factors must be controlled for, as well as controlling for developments in the tax burden

\footnotetext{
${ }^{1}$ The definition of different monetary aggregates varies by country; this is discussed further in Section 3.

${ }^{2}$ For a general overview of the different methods to estimate the shadow economy see Schneider and Enste (2000), Feld and Schneider (2010), Schneider and Collins (2015) and Collins and Schneider (2016).
} 
and government regulation which are assumed to be major factors incentivising individuals to work in the shadow economy (Feld and Schneider, 2010). The excess increase in currency holdings (the amount unexplained by the explanatory variables) is then attributed to the shadow economy.

Figure 2:

United States Currency Ratio 1870-2015

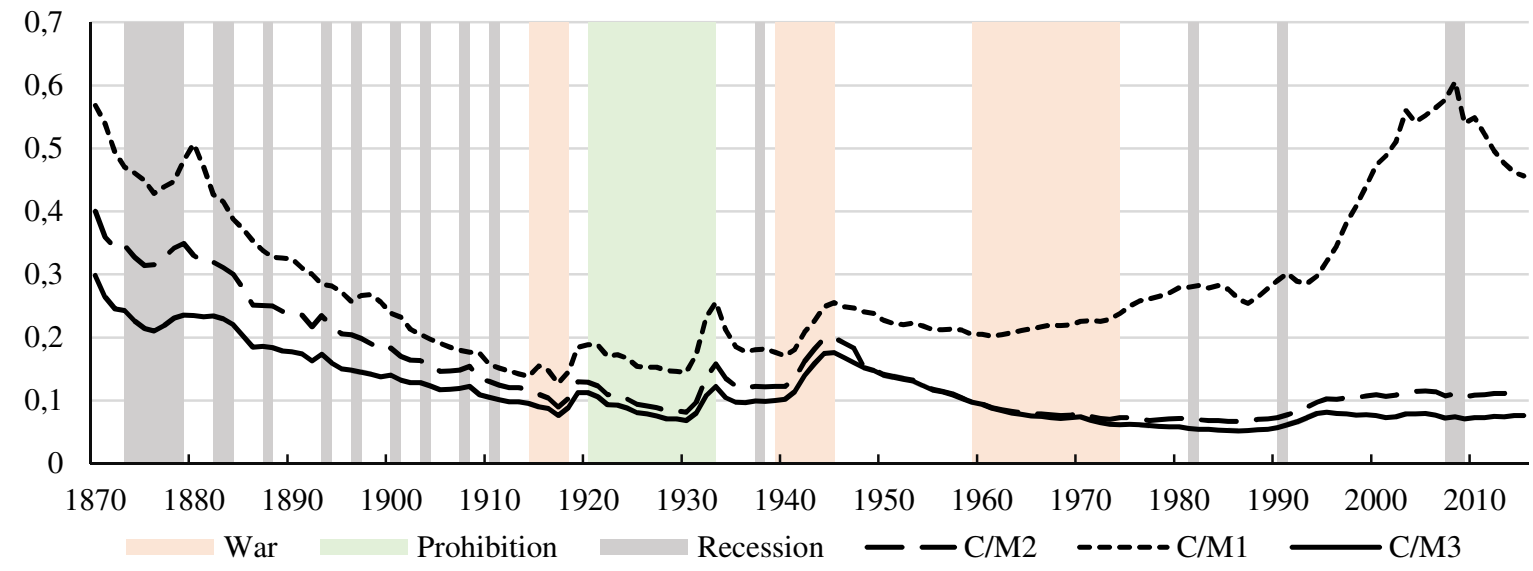

Source: Own calculations

Figure 2 and Figure 3 provide a graphic illustration of the currency ratio in the two Anglophone countries in the panel. The ratio of Currency in Circulation to M1, M2 and M3 has fluctuated widely over time, with the C/M1 ratio declining from 0.6 to .015 in 1913 , before peaking again in 2008. Recessions (lasting more than 12 months) are indicated in grey on the chart and appear to be associated with an increase in the C/M1 ratio, especially during the Great Depression. Prohibition is associated with a decrese in the the currency ratio. Both World War I and II as well as the Vietnam War have been associated with an increase in the ratio of C/M1. The ratio of C/M2 and C/M3 seem to move in lockstep until the turn of the millennium after which the relationship disappeared. 
Figure 3:

United Kingdom Currency Ratio 1880-2015

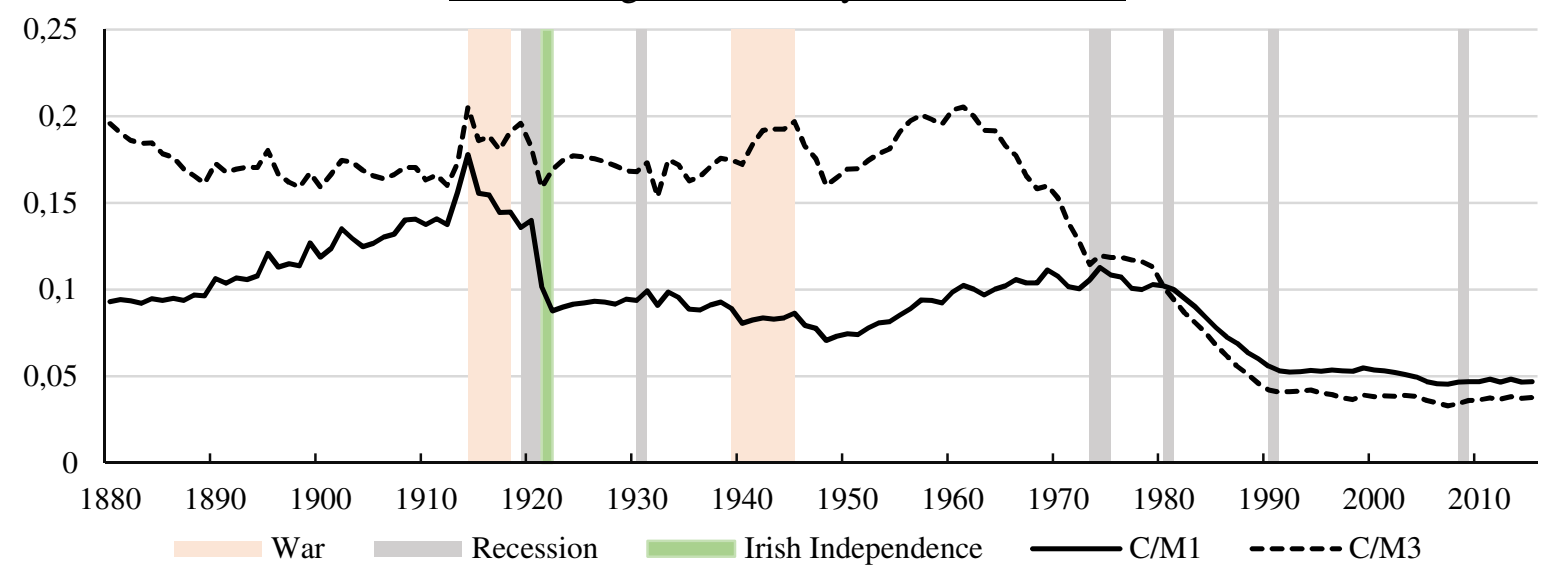

Source: Own calculations

Figure 3 Shows how the currency ratio in the UK reacted to major events. World War I and II brought about an increase in the ratio of C/M1 indicating that people were holding more currency, potentially for use in the underground economy. The recession post World War I appears to have brought about a decrease in the currency ratio.

Figure 4:

Norwegian Currency Ratio 1870-2015

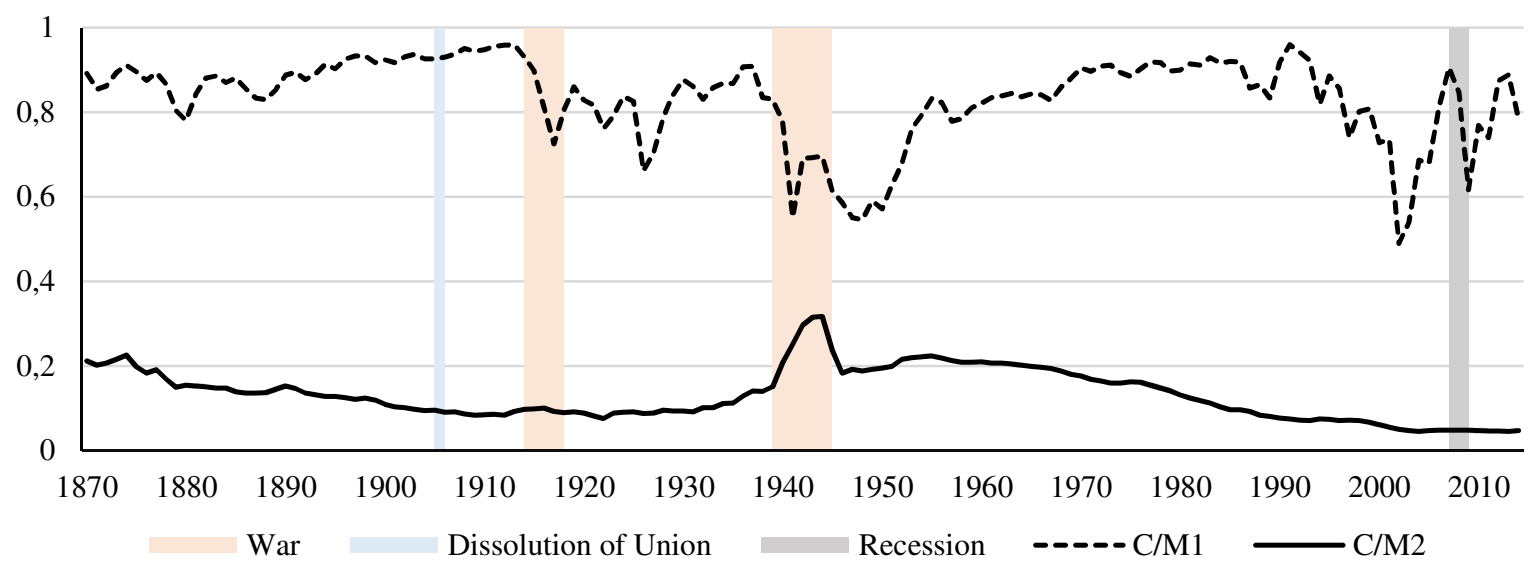

Source: Own calculations

Norway is unique in this study in that it is the only country that shows a large decrease in the currency ratio during both World War I and II (however it subsequently increased). The Global Financial Crisis of 2008 led to a large decrease in the ratio of C/M1 in Norway. 


\section{Figure 5:}

$\underline{\text { Swedish Currency Ratio 1870-2015 }}$

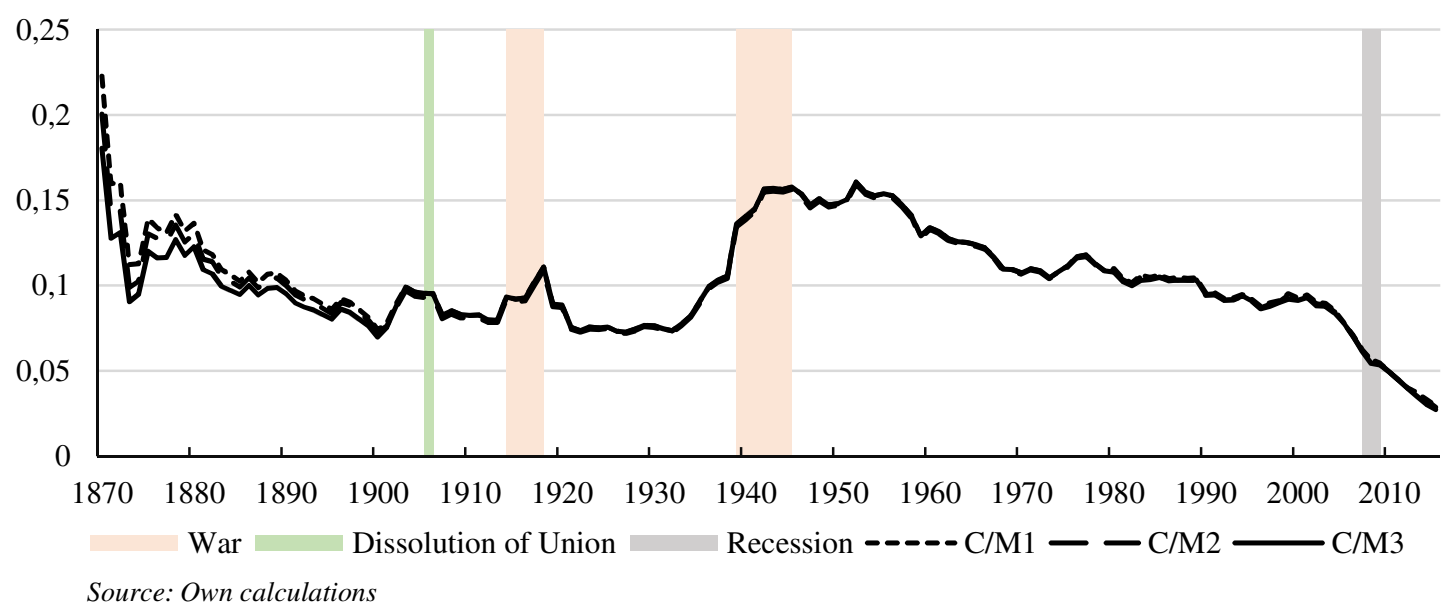

Figure 5 shows the ratios of C/M1 C/M2, and C/M3 moving in close formation in Sweden. The peaceful dissolution of the union between Sweden and Norway does not appear to have a had a major impact on the currency ratio however the outbreak of both World Wars led to large increases in the ratio of C/M1 and C/M2 in Sweden.

While many papers have empirically examined the contemporary shadow economy, few have cast an eye back as far the first half of the $20^{\text {th }}$ century and to this author's knowledge none have examined the late $19^{\text {th }}$ century. The earliest estimates of the size of the shadow economy are those of Tanzi (1983) who approximates the size of the underground economy in the US for the years 1930-1980. However, these estimates have come under criticism in their own right from Hassan and Scheider (2016) citing the flawed assumption on Tanzi's part that the velocity of money is the same in both the legal and illegal economy ${ }^{3}$, leading to inaccurate estimates.

\subsection{Historical context}

Charting the development of the clandestine economy over such a long period as the one in this study brings its own challenges. A century of change and innovation, in terms of financial innovation altered the where and the way in which individuals did business. Banking, and in particular, holding an account, which was once considered the preserve of the elite in the early $19^{\text {th }}$ century, is now

\footnotetext{
${ }^{3}$ A correction for this a la Ahumuda et al. (2007) is discussed in the following section,
} 
commonplace (World Bank, 2009). The cheque book which facilitated transactions and reduced the need to carry cash made way for debit card and other forms of plastic money. Indeed, the physical act of visiting a bank branch is becoming less common as more and more financial services move online. From the comfort of one's own home money can be sent to or spent in any corner of the world, further reducing the need for individuals to carry out transactions in currency. The Classic and Interwar Gold Standards were considered the Good Housekeeping Seal of Approval (Eichengreen, 1992), and countries which adhered to the rules benefitted from lower interest rates (ibid.). The idea of a currency not pegged to bullion was unthinkable and caused must discontent among them public, causing panics and almost causing a run on the Bank of England who used interest rates and borrowed unashamedly to stay afloat.

However, changes were not only confined to the financial sector. Each of the four countries in this panel have experienced exogenous and endogenous shocks ${ }^{4}$; inflationary, technological and political. Some of these shocks were shared, for example each of the four countries were affected by World War Two, Norway with its government in exile was occupied by Nazi forces, Sweden maintained its neutrality but made concessions to both sides. The United Kingdom was a major belligerent in the war as was the United States who joined in the later years. These wars had major effects on employment and spending. The introduction of the rationing of goods was meant to limit shortages and ensure the wartime population had sufficient nutrition. However, this strict rationing led to inevitable increase in black market activity (Thomas, 2003). The bloody tatonnement of the trenches of the Somme and the dogged victory on the bloodstained beaches of Normandy brought about the need for increased taxes and import tariffs to finance the war effort. This increase in import tariffs gave rise to smuggling and tax evasion (Hilson, 2008). During this period global economies flirted with different schools of economic thought, but by the end of World War II (in our panel of countries at least) the ballot box of democracy had safely eradicated the political ideologies that threatened to emerge from the barrel of the Marxist gun.

\footnotetext{
${ }^{4}$ Where shock is meant in the economic sense of an unexpected or unpredictable event that affects an economy, either positively or negatively
} 
Other shocks were felt in isolation, the peaceful dissolution of the Union between Sweden and Norway in 1905 would not have sent shockwaves across the Atlantic (Hilson,2008) but would have important economic ramifications for the countries involved in terms of autonomous formulation of monetary policy and international trade (Klovland, 1983)

In the United States the nationwide constitutional ban on the production, importation and sale of alcoholic beverages during the period 1920-1933 became the largest source of illegal income and jobs (Orkent, 2010). Before the advent of modern income tax, customs duties and liquor taxation accounted for up to $75 \%$ of federal government revenue. (Boudreaux, 2008). Prohibition, is a prime example of a once legal transaction that became illegal overnight. The unintentional effect of prohibition was that it allowed organised crime to flourish, particularly the activities of the American Mafia, (Woodiwiss, 1987) this in turn increased the amount of shadow economic activity (ibid.). Popular and expert opinion today and at the time consider the policy of prohibition a failed experiment (Vitaliano, 2015). Prohibition led to thousands of job losses in the brewing, distilling, barrel making, transportation and restaurant businesses (Orkent, 2010). The sums of money being exchanged during this dry era meant that corruption and bribe-taking was rampant in the federal Bureau of Prohibition. The godfather of bootlegging illegal liquor, Al Capone, is estimated to have made $\$ 60$ million per year from the sale of illegal beer alone, (Kobler, 1971) as well as running over 10,000 speakeasies (ibid.). This $\$ 60 \mathrm{~m}$ figure represents a loss to the US exchequer in the form of taxes since the money was generated in the shadow economy.

Central Banks govern many issues such as monetary policy and the minting of notes and coins as well as the very definition of monetary aggregates. NorgesBank, Riksbank, and the Bank of England were very much established by the time the US Federal Reserve system of central banking was established in 1913. Caution must be taken when interpreting the definition of currency in circulation in the United States as a result, since many different institutions were printing and minting notes and coins. This is discussed further in Section 3. 


\subsection{The Demand for Currency}

The earliest known work on the demand for currency to this author's knowledge dates from 1958 when Philip Cagan estimated the public's demand for currency relative to the total money supply. Cagan's work on the demand for currency is a cornerstone of this project since it helps distinguish "official" as opposed to "illegal" increases in currency in circulation. His seminal work in 1958 provides the famous currency demand function upon which many papers have been based since

$$
C_{0=\alpha(1+\theta)^{\alpha}} Y_{0}^{\beta} \exp (-\gamma i)
$$

where $\mathrm{C}_{0}$ is observed cash and $\Theta$ represents the variable that incentivises individuals to engage in underground activities, believed to be the tax burden or the intensity of government regulation. This variable is the key variable in the CDA because an increase in $\Theta$ is expected to have a positive impact on currency demand, hence individuals hold more cash for their informal transactions. Y0 is the official GDP which represents the level of transactions in an economy. Other measures of the Y0 can be income per Capita or consumption per Capita. $i$ is the interest rate or inflation rate representing the opportunity cost of holding cash. Finally, the $\mathrm{A}, \alpha, \beta$, and $\gamma$ are the parameters. This equation lends itself to estimating the size of the shadow economy but this is discussed further in Section 3.

Deposits and withdrawals in currency are of interest to monetary policymakers. In particular because they influence bank reserves and since they are not subject to direct control by monetary authorities, they must be factored into open market operations of the central bank when planning monetary measures. Cagan (1958) finds that the currency ratio in the US varied considerably. It was greater than 30 percent in 1879 when gold convertibility was restored and declined to just over 7 percent by 1930. While Cagan cannot immediately explain the reason for this downward trend in the ratio of currency supply he cites factors such as the spread of banking in the US in the years preceding the Great War and an increase in the availability of checking accounts. Cagan states that prior to the introduction of deposit insurance in the 1930s, economic conditions could adversely affect deposits which were seen as less safe than currency. Banks could delay or default on deposit payments if the bank became insolvent. Cagan then goes on to say that "the use of currency to conceal taxable 
transactions was probably higher during and after the war because income tax rates were raised considerably early in World War II". Cagan estimates unreported income of \$15bn in 1945, 60-70 per cent of which can be attributed to the wartime increases in income tax rates.

\subsection{Existing Findings}

Tanzi (1983) highlights the reasons for studying the underground economy, citing the distortion of official macroeconomic variables and the resulting distorted policies that are set in response. By developing a demand-for-currency equation and inferring the change in the tax level on that demand Tanzi estimates that the size of the shadow economy ranged from 0.41 per cent of GNP in 1936 to 4.49 per cent in 1980. He surmises that the demand for currency is a function of the four following variables: Income per capita, the interest rate, the tax burden and the ratio of wages and salaries in National Income. The significance of these variables is described in greater detail in later sections. His findings indicate a shadow economy of between 0.6-6 percent of GDP in the United States between 1929 and 1980, or in monetary terms, between $\$ 0.55 \mathrm{bn}$ and $\$ 159.31 \mathrm{bn}$ during the same time period.

Tanzi (1983) presents disturbing findings in the form of an increasing shadow economy, especially towards the end of the period under observation, he surmises that "this trend was probably influenced by the substantial increase in marginal tax rates over the period $1975-8$ ". This study will borrow from the work of Tanzi in terms of the basic regression equation, however several variables will be added to it to make the model more relevant for today's economy, factors such as cheque payments, debit cards etc. However, Tanzi's work, like most works on the shadow economy make several assumptions, the main one being that shadow economic activity is driven by changes is marginal tax rates. It is with this point that Bhattacharyya (1990) takes umbrage. He criticises Tanzi's estimates since Tanzi is in essence testing theories of tax evasion conditional on the variables under examination.

Kirchgaessner and Schneider (1986) used the currency demand approach, too. A common trend across studies of Schneider is the importance of the tax burden in driving underground activity (Schneider 1986, 1994a,b, 1997, 1998a,b, 2000, 2003b, 2005, 2008 2010). This is due to the fact that taxes affect 
the labour-leisure trade-off and can also stimulate labour supply in the shadow economy. He reiterates that the overall tax burden is a major concern for economists: "Since this difference depends broadly on the social security burden/payments and the overall tax burden, they are key features of the existence and the increase of the shadow economy. The validity of these claims have been reinforced by several other authors such as Tanzi (1980,1983); Thomas (1992); Lippert and Walker (1997); Johnson, Kaufmann, and Zoido-Lobatón (1998a,1998b); Tanzi (1999); Giles (1999a); Mummert and Schneider (2001); Giles and Tedds (2002) and Dell' Anno (2003).

The Norwegian and Swedish shadow economies are of interest to researchers due to the high tax burden in these Nordic countries. Klovland (1984) measures the underground economies in Sweden and Norway and finds a statistically significant relationship between marginal tax rates and shadow economic activity in Sweden but not in Norway. Schneider (1986) estimates the shadow economies in the Nordic countries using the currency demand approach and finds that the size of the Norwegian underground sector was around 3 percent of GDP in 1960 but grew steadily to around 10 percent by the mid-1980s. the Swedish underground sector ballooned from 1.5 percent of GDP in 1960 to 12 percent of GDP by 1985 . More recent work by Schneider (2005) has placed the Swedish shadow economy at around 19 percent of GDP at the turn of the millennium while the results for Norway were similar. According to the same study the United Kingdom and the United States have shadow economies at the smaller end of the scale, measuring 12.5 and 8.7 percent of GDP respectively in the year 2000. In a working paper commissioned by the Riksbank, Guibourg and Segendorf (2007) estimate that the Swedish Shadow economy has grown from 3.8 to 6.5 percent of GDP between 1990 and 2004. This highlights the potential differences in estimates of the shadow economy occurring due to different model specifications. Schneider (2012) as well as a report published by the Norwagian Association of Lawyers (2014) find that the Norwegian underground sector is one of the largest in the group of OECD countries, with estimates of 18 and 14 percent of GDP respectively. 


\section{Methodology}

"The black market was a way of getting around government controls. It was a way of enabling the free market to work. It was a way of opening up, enabling people"

- Milton Friedman, (1974)

\subsection{Currency demand method}

While the intuition behind the estimation approach used in this study, the Currency Demand Approach; is described in depth, we will not discuss other approaches due to a space reason. ${ }^{5}$

While individuals may be reluctant to admit their involvement there are other ways to examine the size of the shadow economy, their supposed untraceable transactions leave a stamp on the monetary aggregates of the country. This indirect method of estimating the size of the underground sector is called the Currency Demand Approach. The main assumption of this approach is that cash is the fuel in the engine of the underground economy. Transactions take place in currency since it is doesn't leave a paper trail for authorities to follow, keeping the activities in the shadows. Isachson and Strom (1985), find that over 80 percent of shadow economic transactions take place in cash. If we could isolate the amount of cash used for illicit activities, we could infer the size of the informal sector. The premise for this approach relies on an examination of the ratio between M0 (currency in circulation) and M1 (or M2), currency in circulation and transaction deposits at depository institutions, (M1 + “near money").

An increase in shadow economic activity would imply that individuals are holding more cash to pay for this increase in activity. They withdraw money from their deposit accounts as a result. M1 falls and M0 increases. However, there are other factors which could cause an increase in the amount of money in circulation: central banks printing more money would lead to a natural increase in $\mathrm{M} 0$, falling interest rates might disincentivise individuals from lodging money in their bank accounts.

5 Compare Feld and Schneider (2010), Schneider and Williams (2013), and Williams and Schneider (2016). 
Similarly, rising interest rates may incentivise individuals to lodge money since they can achieve a return on it. These factors must be taken into account when estimating the demand for currency. In essence we are isolating the increase in M0 that can be attributed to the shadow economy. To estimate this "excess" demand for cash, an econometrically estimated demand for currency equation is developed over time. This is known as the Currency Demand Approach which was pioneered by Cagan in 1958, subsequently by Peter Gutmann in 1977 and by Tanzi (1983).

The dependent variable can be taken as either the ratio of currency to demand deposits or the ratio of currency to $\mathrm{M}_{2}$. After the Great Depression in the US, banks payed only a negligible sum of interest on demand deposits (Tanzi, 1980) so individuals may not have held as much money in demand deposits as the opportunity cost was low. During this period of declining spending, time deposits may have replaced demand deposit accounts as the interest payable was higher. This would lead to a natural decrease in $\mathrm{M}_{1}$ which could not be attributed to the shadow economy. The favoured dependent variable of Schneider and also Kirchgaessner is $\mathrm{M}_{0} / \mathrm{M}_{1}$, or alternatively currency in circulation outside the banking sector normalised by the GDP deflator. The following section sets out the explanatory variables used in the econometric equations and a brief description justifying their inclusion, citing works where they have been employed previously and hypothesising their relationship with the currency ratio

\subsection{Variables used in Estimating the Demand for Currency}

\section{(i) Tax Burden}

One of the key assumptions underpinning the Currency Demand approach to modelling the Shadow Economy is that taxes are the main driver of underground activity. Many empirical studies (Tanzi, 1983; Schneider 1986, 1994, 2005; Fleming 2000; Schneider and Enste, 2000; Hassan and Schneider 2016, Bitzenis et al, 2016) have confirmed the statistically significant, positive relationship between the tax burden and the underground economy. Loayza (1999) concludes from his examination of a panel of Latin American countries that "informal economies arise when governments impose excessive taxes and regulations that they are unable to enforce". Taxes are of interest, too, because they influence the labour-leisure trade-off and can stimulate participation in the informal economy. 
The intuition is that an increase in taxes reduces net (after tax) income and as such it may be more lucrative for individuals to operate in the shadow economy as they may not have to pay taxes at all. The Tax Burden is defined as the revenues collected from taxes on income and profits, social security contributions, taxes levied on goods and services, payroll taxes, taxes on the ownership and transfer of property, and other taxes. An increase in these taxes make goods and services more expensive in the formal market and can incentivise individuals to operate in the informal sector (Loayza 1996; Schneider 2005). In the econometric estimations 1970-2015 the tax burden is represented by the share of total tax burden to GDP as per the OECD definition. In the 1913-1970 period the average and top marginal tax rates are employed. Due to lack of data availability the 1870-1913 period uses the percentage of tax revenue in GDP, which is similar to the tax burden.

Hypothesis 1: The greater the tax burden, the greater the demand for cash payments, ceteris paribus.

(ii) Real GDP

Real GDP is a macroeconomic measure of the value of economic output (all goods and services) in a country in a given year, adjusted for price changes (i.e. inflation or deflation).

Hypothesis 2: The greater the growth of the official economy, the smaller the size of the shadow economy, ceteris paribus.

\section{(iii) $\underline{\text { Interest Rate }}$}

Interest rates have long been used by policymakers to influence the level of investment and spending in an economy especially during the Gold Standard in attempts to control capital flows. A high (low) interest rate on deposit accounts increases (decreases) the opportunity cost of holding currency. Hypothesis 3: the higher the interest rate the lower the demand for cash payments, and thus the shadow economy, ceteris paribus.

\section{(iv) Unemployment Rate}

Hypothesis 4: The greater the level of unemployment in a country, the greater the demand for cash payments, ceteris paribus. 


\section{(v) Self-employment rate}

Self-employed individuals are often faced with bureaucracy and legislation when setting up business. Schneider and Enste (2002) and Hassan and Schneider (2016) cite this bureaucracy as a driver of underground activity.

Hypothesis 5: The greater the number of self-employed individuals in a country, the greater the demand for cash payments, ceteris paribus.

\section{(vi) Crime}

Since a large component of the shadow economy is illegal activity, in addition to the traditional explanatory variables we introduce a criminal element, in an attempt to separate the illegal cashsettled economy from underground production.

Hypothesis 6: An increase in crime (fraud) leads to an increase in the demand for cash payments, ceteris paribus.

\section{(vii) Wages and Salaries in National Income}

Hypothesis 7: An increase in wages and salaries in National Income leads to an increase in the demand for cash payments, ceteris paribus.

\section{(viii) Social Welfare spending as a percentage of Total Government Spending}

Hypothesis 8: The higher government spending on social welfare the larger the demand for cash, ceteris paribus

\section{(ix) Civic employment}

Hypothesis 9: An increase in public sector employment leads to an increase in the shadow economy, ceteris paribus.

\subsection{Additional remarks}

The type of model run varies by period. Due to data limitations the model run for the $1870-1913$ period is an OLS model similar to the one employed by Tanzi (1980) where estimates have been 
corrected for serial autocorrelation. The 1913-1970 and 1970-2015 periods employ a Vector Error Correction model as used by Macias and Cazzavillan (2009) and Hassan and Schneider (2016). This method is superior to standard OLS since it allows us to capture both long and short-run effects. VEC Model estimates will be more efficient (as a VECM has a restricted VAR representation) (Christofferson and Diebold, 1998). This is examined in more detail in section 4.

\title{
4 Empirical Results
}

\author{
"The income tax created more criminals than any other single act of \\ government."
}

- Barry Goldwater, Republican Party Nominee for

President of the US, 1964

\subsection{From Civil War to the Somme: 1870- 1913}

The vast array of data available for contemporary shadow economic estimations is not available for this time period so the regression equations are rather rudimentary. The skeleton of the regression equations is taken from Tanzi (1980) who uses only 4 variables to determine the long run behaviour on the currency ratio (C/M2): Income per capita, the interest rate, the tax burden and the share of wages and salaries in National Income.

The model used to estimate the shadow economy in the UK is as follows:

$$
C / M 2=\alpha_{0}+\alpha_{1}\left(\text { Y/capita }_{t}\right)+\alpha_{2} R_{t}+\alpha_{3}\left(1+T A X_{t}\right)+\alpha_{4}\left(\text { WELFARE }_{t}\right)+\varepsilon_{t}
$$

The independent variables are real Income per Capita (Y/Capita), the rate of interest paid on time deposits (R), the amount of government spending on welfare (WELFARE) and the tax variable $(1+T)$. Income tax as we know it today was introduced in the UK in the years preceding World War 1, finding a consistent variable to capture the effect of taxation prior to 1913 is difficult so we have used 
the amount of tax revenue collected each year as a percentage of GNP to act as the tax burden. Having become the hegemonic power of the $19^{\text {th }}$ Century through its supremacy in industry and railroads the United Kingdom was a frontrunner in innovation, with a keen interest in the welfare of its citizens. A reform which had a major impact on the population was the Public Health Act of 1872, which led to the establishment of health authorities around England and provided funding for housing, water and disease prevention, financed through local government taxes. The inclusion of this WELFARE variable has its roots in the findings of Schneider (2000), who finds that social security contributions have a positive effect on the size of the shadow economy. Since these reforms were achieved through an increase in the tax rate, this is hypothesised to lead to more demand for currency.

The coefficients of the regression as well as other information are displayed in Table 2 alongside the regression results for Norway, Sweden, and the United States. This was done to aid cross-country comparisons.

For Norway and Sweden, the following econometric equation from Tanzi (1980) has been employed:

$$
C / M 2=\alpha_{0}+\alpha_{1}\left(\text { Y/capita }_{t}\right)+\alpha_{2} R_{t}+\alpha_{3}\left(1+T A X_{t}\right)+\alpha_{4}\left(\text { WAGES }_{t}\right)+\varepsilon_{t}
$$

The econometric equation used for the United States is the same as that used for Norway and Sweden with the inclusion of total expenditure as an additional explanatory variable to put further pressure on the demand for currency. The tax burden has been estimated in the same way as for the United Kingdom, total tax revenue as a percentage of GNP. The equation reads as follows:

$$
C / M 2=\alpha_{0}+\alpha_{1}\left(\text { Y/capita }_{t}\right)+\alpha_{2} R_{t}+\alpha_{3}\left(1+\text { TAX }_{t}\right)+\alpha_{4}\left(\text { WAGES }_{t}\right)+\alpha_{5}(\text { TOTEXP })+\varepsilon_{t}
$$




\subsubsection{Estimation/Regression Results}

Total Expenditure is expected to have a negative effect on the demand for currency ratio, since an increase in government spending may appease individuals who feel overburdened by the tax level since they may feel that they are receiving better value for money from their tax payments. The results from the regression equation are found in table 1 below. The results are highly statistically significant with a high $\mathrm{R}^{2}$ implying that most of the variation in $\ln \mathrm{C} / \mathrm{M} 2$ can be explained by the estimated equations.

Income per capita is strongly, positively, statistically significant for the UK and Norway, however it is negative for Sweden and the US, implying that shadow economic activity moves in lockstep with economic development in the UK and Norway while in Sweden and the US the opposite is true. The interest rate has a negative effect on the currency ratio in the UK, Norway and the US which is intuitive since if the interest rate rises, the amount of currency in circulation should fall due to an increase in the opportunity cost of holding money. At odds with the results of Tanzi (1980) there is no statistically significant relationship between wages and salaries in national income and the currency ratio. The tax burden is the only variable which has a consistent sign across the panel of countries and is significant at the 1 per cent level. This implies that an increase in the tax burden leads to an increase in the currency ratio. To test for autocorrelation among the residuals the Durbin-Watson statistic was calculated. The results are greater than 1.71 for the panel of countries, indicating that autocorrelation among residuals is not a major cause for concern, with a $\mathrm{D}-\mathrm{W}$ of 1.98 , and an $\mathrm{R}^{2}$ of .94 the estimates for the United Kingdom are the best statistical fit. 
Table 1:

\begin{tabular}{|c|c|c|c|c|}
\hline \multicolumn{5}{|c|}{ OLS Results for Demand for Currency Ratio 1870-1913 } \\
\hline Country & United Kingdom & Norway & Sweden & United States \\
\hline Dependent Variable & $\mathrm{C} / \mathrm{Mr}_{\mathrm{t}-1}$ & $\mathrm{C} / \mathrm{M}_{\mathrm{t}-1}$ & $\mathrm{C} / \mathrm{M}_{\mathrm{t}-1}$ & $\mathrm{C} / \mathrm{M}_{\mathrm{t}-1}$ \\
\hline \multirow{2}{*}{ Income per capita $\mathrm{t}_{\mathrm{t}-1}$ (Y/Capita) } & $1.115^{* * *}$ & $0.367 * * *$ & $-0.455 * * *$ & $-1.466 * * *$ \\
\hline & $(0.164)$ & $(0.0591)$ & $(0.102)$ & $(0.104)$ \\
\hline \multirow{2}{*}{ Interest Rate ${ }_{\mathrm{t}-1}(R)$} & -0.000772 & $-0.185^{* * *}$ & $0.965 * * *$ & $-0.411 * * *$ \\
\hline & $(0.129)$ & $(0.0436)$ & $(0.219)$ & $(0.0828)$ \\
\hline \multirow{2}{*}{ Wages $_{\mathrm{t}-1}$ (Wages) } & & -0.193 & 0.394 & 0.0952 \\
\hline & & $(0.120)$ & $(0.377)$ & $(0.349)$ \\
\hline \multirow[t]{2}{*}{ Tax Burden $(1+T)$} & $0.122 * * *$ & $2.763 * *$ & $4.151 * *$ & $9.036 * * *$ \\
\hline & $(0.0391)$ & $(1.205)$ & $(2.015)$ & $(2.712)$ \\
\hline \multirow[t]{2}{*}{ Welfare $_{\mathrm{t}-1}($ WELFARE $)$} & $0.233 * * *$ & & & \\
\hline & $(0.0691)$ & & & \\
\hline \multirow[t]{2}{*}{ Total Expenditure $_{\mathrm{t}-1}($ TOTEXP) } & & & & $-0.754 * * *$ \\
\hline & & & & $(0.0865)$ \\
\hline \multirow[t]{2}{*}{ Constant } & $-11.50 * * *$ & $-3.748 * * *$ & -0.159 & $12.44 * * *$ \\
\hline & $(1.284)$ & $(0.731)$ & $(1.723)$ & $(1.449)$ \\
\hline Observations & 31 & 42 & 42 & 44 \\
\hline R-squared & 0.94 & 0.74 & 0.69 & .95 \\
\hline D-Watson & 1.98 & 1.71 & 1.80 & 1.88 \\
\hline
\end{tabular}

\subsubsection{Calculation of the Size of the Shadow Economy over 1870-2013}

In order to obtain estimates of the size of the shadow economy we use the following method: For each year the predicted level of the currency ratio $\mathrm{C} / \mathrm{M} 2$ can be calculated using the regression equations found in table $\mathrm{X}$. The predicted level of currency holding $-\hat{\mathrm{C}}-\mathrm{can}$ be calculated given the actual figure for M2 following the method used by Tanzi (1980):

Let the dependent variable in the preceding econometric equation be represented by $\mathrm{Z}$. Therefore

$$
Z=\ln (C / M 2)=\ln C-\operatorname{Ln} M 2
$$

If we rewrite this equation in terms of $\ln C$ we get

$$
\ln C=Z+\ln M 2
$$


where the circumflex above the $\mathrm{C}$ represents the predicted value from the econometric equation,

solving this equation results in:

$$
\hat{C}=\exp (Z+\ln M 2)
$$

This represents the value of currency at time $t$ predicted by the econometric equations. The next step is to set the tax variable equal to its lowest value, keeping all the other coefficients unchanged to obtain $C^{\prime}$, the predicted level of currency in circulation without taxes. This is done by following the same procedure outlined above. The difference between the two variables $\hat{C}$ and $\dot{C}$ gives us the amount of extra currency in the economy.

Using the Ahumada et al (2007) approach of circumventing the issue of differing velocities of money between the legal and illegal economy

$$
\begin{gathered}
\frac{Y_{\text {informal }}}{Y_{\text {formal }}}=\left(\frac{C_{\text {informal }}}{C_{\text {formal }}}\right)^{\frac{1}{\alpha}}=\left(\frac{Y_{\text {informal }}}{Y_{\text {formal }}}\right)^{\frac{1}{\alpha}} \\
\left(\frac{17.32}{133}\right)^{\frac{1}{1.115}}=.168=16.8 \%
\end{gathered}
$$

This implies that the size of the UK shadow economy as a percentage of UK GDP in 1884 was $16.8 \%$. This process is repeated for the remaining years and the remaining countries to produce estimates for the size of the shadow economy. These are presented in Figures 6 below. 


\section{Figure 6:}

Shadow Economy as a percentage of GDP 1870-1913
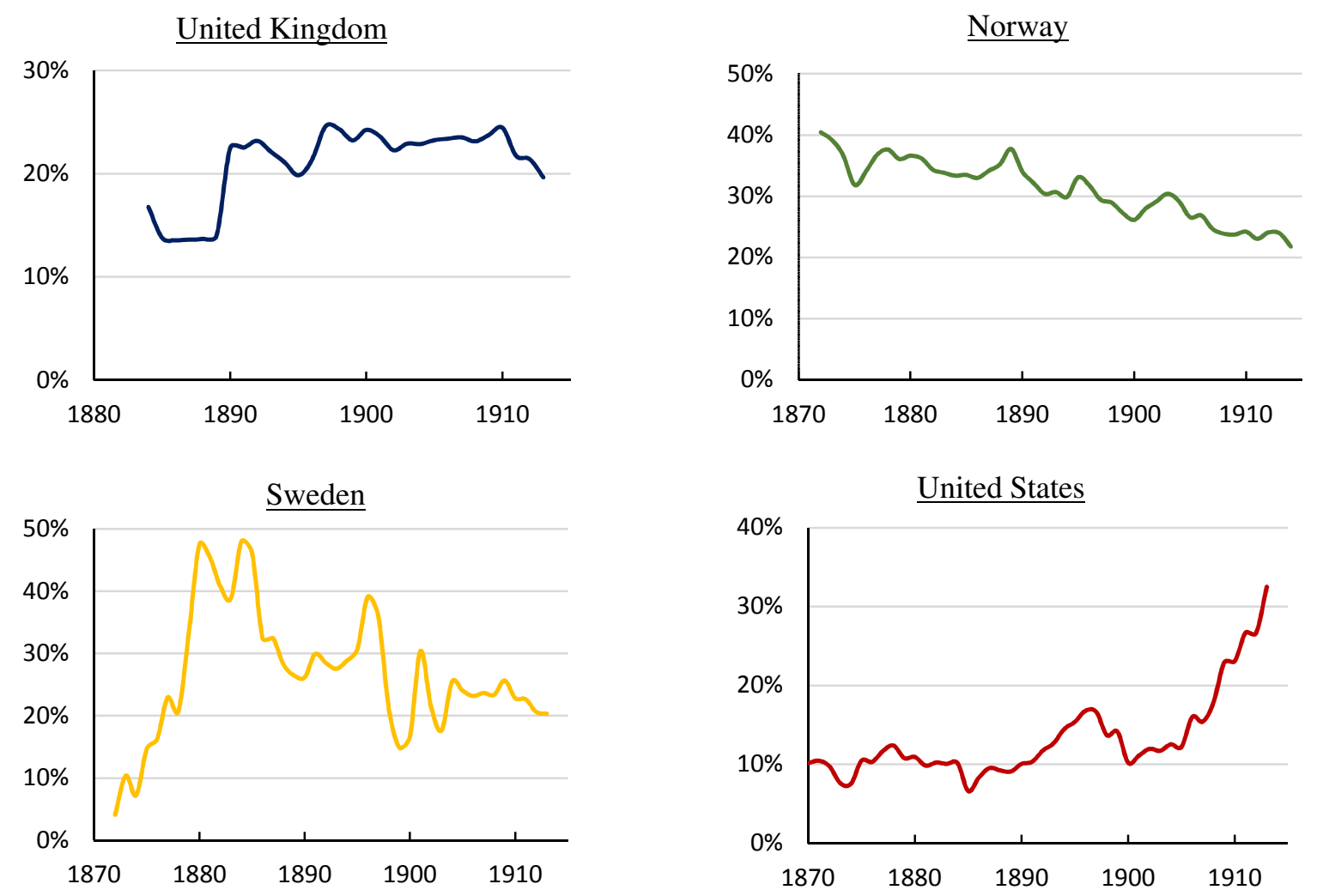

Source: Own Calculations

Figure 6 depicts a wide variation in the size of shadow economies across the panel of countries. In the case of the United States the shadow economy remained relatively stable (approximately 10 percent of GDP) from 1870 until 1905 before it began to increase to close to 30 percent of GDP at the start of World War 1. The United Kingdom also remained relatively stable after 1890 at just over 20 percent of GDP. Norway displays a pronounced downward trend in the size of its shadow economy, from 40 percent of GDP in 1970 to 24 percent before the start of World War 1. Sweden on the other hand displays a very erratic shadow economy that fluctuates from between 4 and 47 percent of GDP. The Swedish and Norwegian shadow economies experienced a small increase in the year after the peaceful dissolution of their Union in 1905. However, it does begin to stabilise towards the end of the period. 
The three European shadow economies in the panel show signs of convergence towards the end of the period.

\subsection{From the Somme to Saigon 1913-1970}

The next period under examination is 1913-1970. This period is more interesting than the 1880-1913 period discussed above due to the major shifts in geopolitics and ideologies, brought about by two major international conflicts as well as the Great Depression of 1931. To capture the long run effects of the explanatory variables on currency demand the following econometric equation has been estimated:

$$
\begin{gathered}
C / M 2=\alpha_{0}+\alpha_{l}\left(\text { Y/capita }_{t}\right)+\alpha_{2} R_{t}+\alpha_{3}\left(1+\text { TAX }_{t}\right)+\alpha_{4}\left(\text { REG }_{t}\right)+\alpha_{5}\left(\text { UNEMP }_{t}\right)+\alpha_{6}\left(\text { CRIME }_{t}\right) \\
+(\text { TOTEXP })+\varepsilon_{t}(\mathbf{4})
\end{gathered}
$$

The model for Sweden is displayed in equation (5), all variables are in natural logarithms and the dependent variable is again C/M2 . For Sweden the model run is similar to the United Kingdom except that a variable capturing the effects of the self-employment rate (SELF) on the currency ratio is included.

$C / M 2=\alpha_{0}+\alpha_{1}\left(\right.$ Y/capita $\left._{t}\right)+\alpha_{2} R_{t}+\alpha_{3}\left(1+\right.$ TAX $\left._{t}\right)+\alpha_{4}\left(\right.$ REG $\left._{t}\right)+\alpha_{5}\left(\right.$ SELF $\left._{t}\right)+\alpha_{6}\left(\right.$ WAGES $\left._{t}\right)+\varepsilon_{t}$

The model used to estimate the US shadow economy is a VEC model where the dependent variable is again the natural logarithm of $\mathrm{C} / \mathrm{m} 2$. The usual due diligence steps were taken to ensure Unit Root and Cointegration. 
$C / M 2=\alpha_{0}+\alpha_{l}\left(\right.$ Y/Capita $\left._{t}\right)+\alpha_{2} R_{t}+\alpha_{3}\left(1+\right.$ TAX $\left._{t}\right)+\alpha_{4}\left(\right.$ WELFARE $\left._{t}\right)+\alpha_{5}($ WAGES $)+\alpha_{6}\left(\right.$ CRIME $\left._{t}\right)+$

$\alpha_{7}(U N E M P)+\varepsilon_{t}$

Only four explanatory variables are employed in the case of the Norway 1913-1970 due to data limitations. This is quite disappointing since it would be interesting to compare both Scandinavian countries which are culturally and economically similar. However, an OLS model is run using a skeleton similar to Tanzi (1980) and employed in the 1870-1913 period:

C/M2 $=\alpha_{0}+\alpha_{1}\left(\right.$ Y/Capita $\left._{t}\right)+\alpha_{2} R_{t}+\alpha_{3}(1+$ TAX $t)+\alpha_{4}\left(\right.$ WAGES $\left._{t}\right)+\varepsilon_{t}$

\subsubsection{Econometric Results}

The coefficients of the previous four econometric equations are displayed in Table 2 below. The relationship between economic development and the currency ratio is statistically significant negative in the case of the Scandinavian countries and the US, implying that the shadow economy is countercyclical to economic growth. The opposite is true in the UK. The interest rate is negative yet insignificant in the UK, Norway and Sweden but positive and significant at the 1 percent level in the US, implying that an increase in interest rate leads to an increase in the currency ratio in the long term. Self-employment leads to a decrease in the currency ratio in Sweden, this is statistically significant however there is no data available for other countries to check the robustness of this variable, so it could potentially be a spurious correlation. Unemployment is significantly positively correlated with the currency ratio at the 1 percent level. Incidence of fraud which proxies for morality of paying taxes is positively significantly associated with the currency ratio, implying that an increase in fraud in a country increases the currency ratio. 
Table 2:

\begin{tabular}{|c|c|c|c|c|}
\hline \multicolumn{5}{|c|}{ Normalized Cointegrating Coefficients 1913-1970 } \\
\hline & United Kingdom & Norway & Sweden & United States \\
\hline Dependent Variable & $\mathrm{C} / \mathrm{M} 1_{\mathrm{t}-1}^{\mathrm{a}}$ & $\mathrm{C} / \mathrm{M}^{\mathrm{a}}{ }_{\mathrm{t}-1}$ & $\mathrm{C} / \mathrm{M} 2^{\mathrm{b}}{ }_{\mathrm{t}-1}$ & $\mathrm{C} / \mathrm{M} 2_{\mathrm{t}-1}^{\mathrm{b}}$ \\
\hline & 1.00 & OLS & 1.00 & 1.00 \\
\hline Income $_{t-1}$ & $\begin{array}{l}\text { 15.73* } \\
(8.35)\end{array}$ & $\begin{array}{c}-\mathbf{- 0 . 8 4 7 * *} \\
(0.42)\end{array}$ & & \\
\hline $\begin{array}{l}\text { Income per capita } \\
\text { (Y/Capita) }\end{array}$ & & & $\begin{array}{c}-\mathbf{1 . 8 6 6 * * * *} \\
(0.41)\end{array}$ & $\begin{array}{c}-\mathbf{0 . 6 7 8} * * * \\
(0.14)\end{array}$ \\
\hline Interest Rate $_{\mathbf{t}-\mathbf{1}}(R)$ & $\begin{array}{l}\mathbf{- 2 . 7 4 5} \\
(4.13)\end{array}$ & $\begin{array}{r}\mathbf{- 0 . 4 3 4} \\
(0.33)\end{array}$ & $\begin{array}{r}-\mathbf{0 . 4 5 2} \\
(0.29)\end{array}$ & $\begin{array}{c}\mathbf{0 . 4 6 6 * * * *} \\
(0.06)\end{array}$ \\
\hline Public Sector $_{\mathrm{t}-1}(R E G)$ & $\begin{array}{c}\mathbf{- 5 8 . 5 3 * * * *} \\
(12.57)\end{array}$ & & $\begin{array}{c}-\mathbf{2 . 0 0 9} * * * \\
(0.38)\end{array}$ & \\
\hline Tax Burden $_{t-1}(1+T)$ & $\begin{array}{c}\mathbf{5 4 . 2 6}^{* * * *} \\
(13.5)\end{array}$ & $\begin{array}{c}4.315 * * \\
(1.68)\end{array}$ & $\begin{array}{c}\text { 4.036*** } \\
(1.32)\end{array}$ & $\begin{array}{l}\mathbf{1 . 0 5 9} * \\
(0.60)\end{array}$ \\
\hline Self-Employment $_{t-1}(S E L F)$ & & & $\begin{array}{c}-1.904 * * * \\
(0.66)\end{array}$ & \\
\hline Unemployment $_{\mathrm{t}-\mathbf{1}}(U N E M P)$ & $\begin{array}{c}\mathbf{3 . 0 5 8}^{* * * *} \\
(1.16)\end{array}$ & & & $\begin{array}{c}\mathbf{2 . 5 3 8} * * * \\
(0.58)\end{array}$ \\
\hline Fraud Incidence $_{t-1}(C R I M E)$ & $\begin{array}{c}\mathbf{0 . 1 3 0} * * \\
(0.07)\end{array}$ & & & $\begin{array}{c}\mathbf{0 . 3 5 8} * * * \\
(0.11)\end{array}$ \\
\hline $\begin{array}{l}\text { Wages in National Income } \\
\text { (WAGES) }\end{array}$ & & $\begin{array}{c}\mathbf{- 1 . 5 5 4} * * * \\
(0.53)\end{array}$ & $\begin{array}{c}\mathbf{6 . 0 7 9} * * * \\
(0.64)\end{array}$ & $\begin{array}{c}-4.732 * * * \\
(1.72)\end{array}$ \\
\hline Welfare $_{\mathrm{t}-\mathbf{1}}(W E L F A R E)$ & & & & $\begin{array}{c}\mathbf{0 . 4 4 2} * * * \\
(0.15)\end{array}$ \\
\hline $\begin{array}{l}\text { Total Expenditure }_{\mathrm{t}-\mathbf{1}} \\
(\text { TOTEXP) }\end{array}$ & $\begin{array}{c}\mathbf{- 1 . 7 2 5 * * * *} \\
(0.32)\end{array}$ & & & \\
\hline Constant & $\begin{array}{c}12.52 * * * \\
(2.58)\end{array}$ & $\begin{array}{c}14.21 * * \\
(6.16)\end{array}$ & $\begin{array}{l}\mathbf{8 . 0 5 5} \\
(5.38) \\
\end{array}$ & $\begin{array}{c}27.45 * * * \\
(5.93)\end{array}$ \\
\hline Observations & 56 & 55 & 58 & 58 \\
\hline Log Likelihood (D-Watson) & 823.01 & $(2.01)$ & 922.84 & 674.99 \\
\hline$x^{2}$ & 189.77 & - & 336.23 & 425.70 \\
\hline Trace Statistic 5\% & 2 & - & 1 & 3 \\
\hline Max Eigenvalue Statistic 5\% & 2 & - & 1 & 3 \\
\hline $\begin{array}{l}\text { All variables are in natural logs. } \\
\text { Standard Errors presented in parentheses. } \\
*, * *, * * * \text { indicate significance at the } 10,5 \\
\text { The number of lags in the models were det } \\
\text { criterion (SBIC) and the Hannan and Quin } \\
\text { a } \\
\text { b The model was run with } 1 \text { lag. } \\
\text { b The model was run with } 4 \text { lags. } \\
\text { Source: own calculations }\end{array}$ & $\begin{array}{l}\text { d } 1 \text { percent level respective } \\
\text { ined using Akaike's inform } \\
\text { ormation criterion (HQIC) }\end{array}$ & criterion & 'chwarz's Baye & information \\
\hline
\end{tabular}




\subsubsection{Calculation of the Size of the Shadow Economy over 1913-2015}

After estimating the VECM and having obtained the coefficients displayed in Table 3 we can now calculate the size of the shadow economy. The first step again is to calculate $\hat{\mathrm{C}}$, the predicted level of currency holding using the method outlined in the previous section. We then set the tax burden, public sector employment and in the case of Sweden, self-employment, to the minimum level to obtain Ć. The difference between $\hat{\mathrm{C}}$ and $\dot{C}$ gives us the extra currency in circulation in the respective economies.

Figure 7:

Shadow Economy as a percentage of GDP 1913-2015
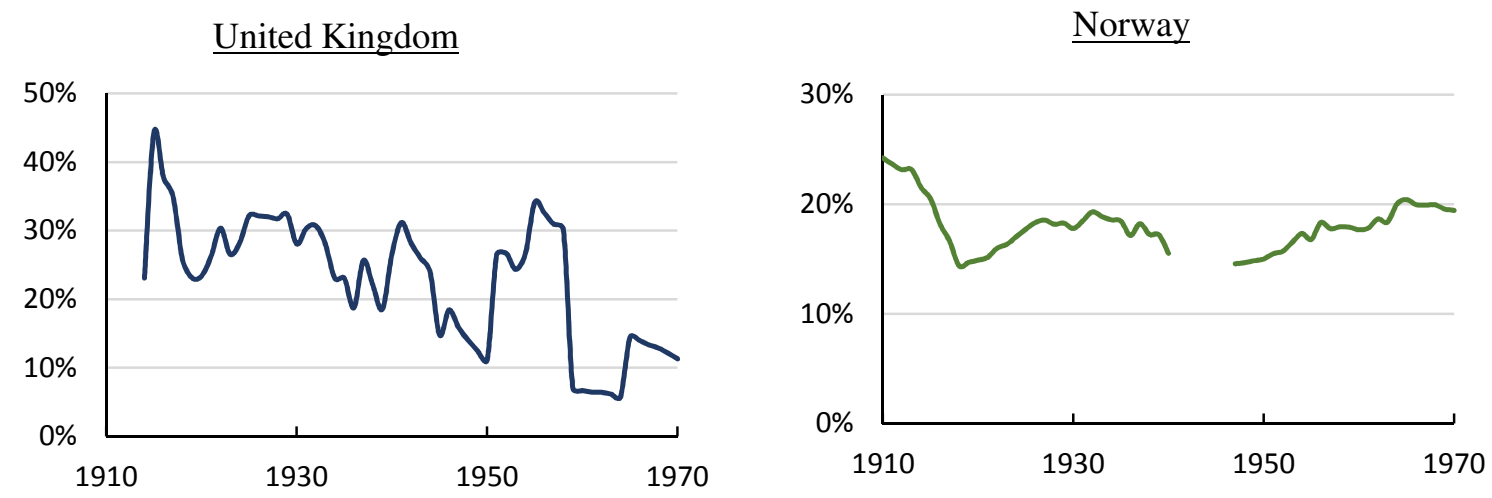

$\underline{\text { Sweden }}$
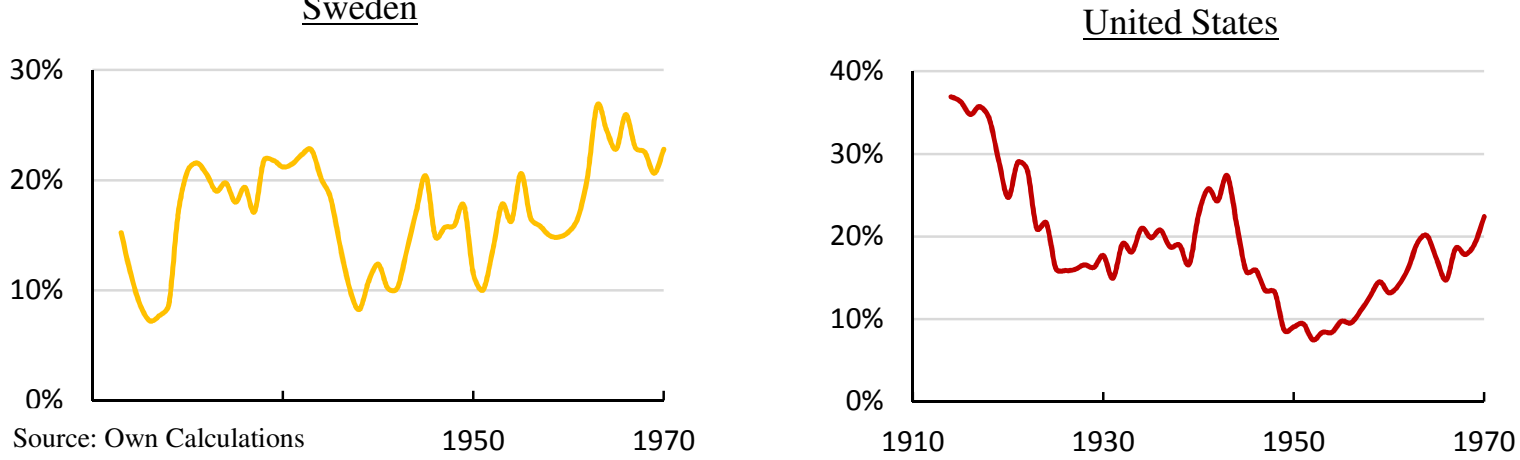

There are again wide fluctuations in the size of the shadow economies in the panel of countries. Norway has a relatively stable shadow economy over the period although missing data for Norwegian GDP during World War Two means we do not have estimates for this period. In the US and the UK underground activity increased by approximately 10 percentage points between 1940 and 1941 . The 
UK had the largest shadow economy as a percentage of GDP in 1915 at 44 percent of GDP, it then rose again spectacularly between 1950 and 1960 (to over 30 percent of GDP). The shadow economies in Norway, Sweden, and the united states converged to approximately 20 percent of GDP in 1970.

Figure 8:

Shadow Economies as a percentage of GDP 1910-1970

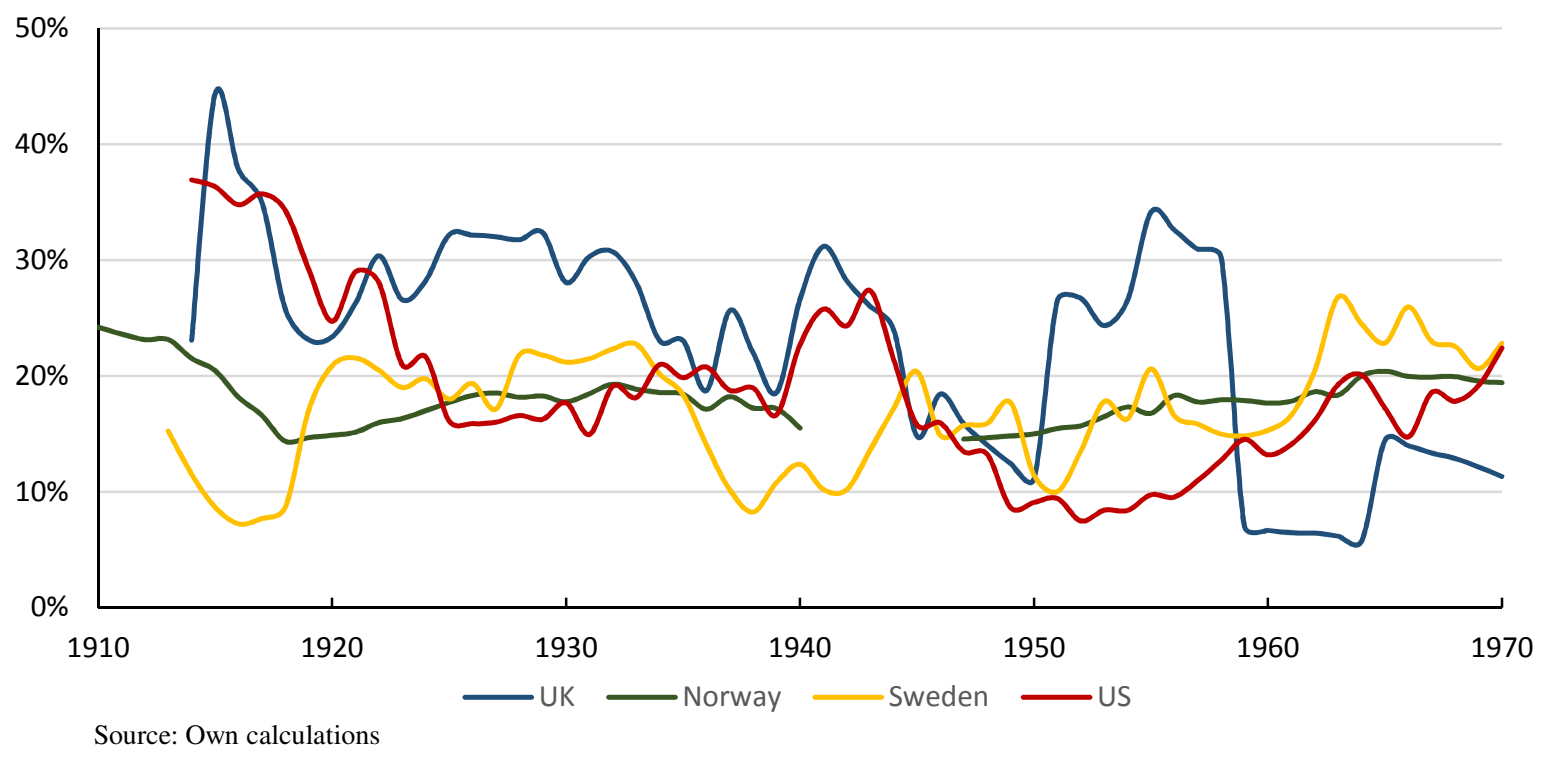

\subsection{From Saigon to the Sub-Prime Crisis 1970-2015}

The most recent period benefits from better quality data, much of which has been gleaned from the OECD website. The Tax Burden in the following equations is a variable available on the OECD website and it encompasses the various forms of taxes that individuals are subject to in each country. The significance and expected sign of all other variables have been discussed at length in previous sections and reiteration would be futile. The VEC model has been used to estimate the currency ratio for the panel of countries.

\section{$\underline{\text { United Kingdom }}$}

$C / M 2=\alpha_{0}+\alpha_{1}\left(Y_{t}\right)+\alpha_{2} R_{t}+\alpha_{3}\left(1+T A X_{t}\right)+\alpha_{4}\left(R E G_{t}\right)+\alpha_{5}\left(S E L F_{t}\right)+\alpha_{6}\left(C_{R I M E_{t}}\right)+\alpha_{7}\left(\right.$ TOTEXP $+\varepsilon_{t}$ 


\section{Norway}

$C / M 2=\alpha_{0}+\alpha_{1}\left(\right.$ Y/Capita $\left._{t}\right)+\alpha_{2} R_{t}+\alpha_{3}\left(1+T A X_{t}\right)+\alpha_{4}\left(R E G_{t}\right)+\alpha_{5}\left(\right.$ SELF $\left._{t}\right)+\alpha_{6}\left(\right.$ CRIME $\left._{t}\right)+\alpha_{7}($ TOTEXP $)+\varepsilon_{t}$

\section{Sweden}

$C / M 2=\alpha_{0}+\alpha_{1}\left(Y_{t}\right)+\alpha_{2} R_{t}+\alpha_{3}\left(1+T A X_{t}\right)+\alpha_{4}\left(R E G_{t}\right)+\alpha_{5}\left(S E L F_{t}\right)+\alpha_{6}\left(C_{R I M E_{t}}\right)+\alpha_{7}\left(\right.$ TOTEXP $+\varepsilon_{t}$

\section{$\underline{\text { United States }}$}

$C / M 2=\alpha_{0}+\alpha_{1}\left(\right.$ Y $\left._{\text {Capita }}\right)+\alpha_{2} R_{t}+\alpha_{3}\left(1+T A X_{t}\right)+\alpha_{4}\left(R E G_{t}\right)+\alpha_{5}\left(\right.$ SELF $\left._{t}\right)+\alpha_{6}\left(\right.$ CRIME $\left._{t}\right)+\alpha_{7}(W E L F A R E)+\varepsilon_{t}$

The results of the VECM are displayed in Table 3. Economic development is implied to be significantly, positively correlated with the currency ratio, as is the interest ratio which seems counterintuitive however the VEC model captures the long run effect which implies that in the long run the currency ratio is positively correlated with the interest rate. In the UK and Norway, the regulatory burden is negatively correlated with the currency ratio, implying that increased regulation disincentivizes shadow economic activity since the detection rate is higher, while the reverse is true in Sweden and the US. The Tax Burden is negatively correlated with the currency ratio in Norway and the US. This is significant at the 1 percent level. This is counterintuitive but it may imply that in Norway and the US there are other factors such as regulation and spending on welfare that are more important determinants of shadow economic activity than simply the tax burden alone. 
Table 3:

Normalized Cointegrating Coefficients 1970-2015

\begin{tabular}{|c|c|c|c|c|}
\hline Country: & United Kingdom & Norway & Sweden & United States \\
\hline Dependent Variable: & $\mathrm{C} / \mathrm{M} 2_{\mathrm{t}-1}$ & $\mathrm{C} / \mathrm{M} 2_{\mathrm{t}-1}$ & $\mathrm{C} / \mathrm{M} 2_{\mathrm{t}-1}$ & $\mathrm{C} / \mathrm{M} 2_{\mathrm{t}-1}$ \\
\hline & 1.00 & 1.00 & 1.00 & 1.00 \\
\hline Income $_{t-1}$ & $\begin{array}{c}\mathbf{1 . 2 0 1} * * * \\
(0.22)\end{array}$ & & $\begin{array}{c}\mathbf{1 . 6 8 8} * * * * \\
(0.05)\end{array}$ & \\
\hline $\begin{array}{l}\text { Income per capita } \text { t-1 }_{(Y / \text { Capita })} \\
\text { (1) }\end{array}$ & & $\begin{array}{c}\text { 3.362 } * * * \\
(0.86)\end{array}$ & & $\begin{array}{c}\mathbf{2 . 3 2 4} * * * \\
(0.29)\end{array}$ \\
\hline Interest Rate $_{\mathbf{t}-\mathbf{1}}(R)$ & $\begin{array}{c}\mathbf{0 . 6 6 4} * * * \\
(.09)\end{array}$ & $\begin{array}{l}\mathbf{0 . 1 7 6} \\
(0.18)\end{array}$ & $\begin{array}{c}\mathbf{0 . 3 8 7} * * * \\
(0.03)\end{array}$ & $\begin{array}{c}\mathbf{0 . 4 8 4} * * * \\
(0.08)\end{array}$ \\
\hline Public Sector $_{\mathrm{t}-1}(R E G)$ & $\begin{array}{c}\mathbf{- 3 . 4 0 7 * * *} \\
(.34)\end{array}$ & $\begin{array}{c}-\mathbf{3 . 3 8 8}^{* * *} \\
(1.14)\end{array}$ & $\begin{array}{c}\text { 0.724*** } \\
(0.17)\end{array}$ & $\begin{array}{c}4.333 * * * \\
(0.84)\end{array}$ \\
\hline $\operatorname{Tax}_{B^{\prime}}$ urden $_{t-1}(1+T)$ & $\begin{array}{c}\mathbf{3 . 4 9 3}^{*} \\
(2.03)\end{array}$ & $\begin{array}{c}\mathbf{- 9 . 8 3 9} * * * \\
(2.55)\end{array}$ & $\begin{array}{c}\text { 4.172*** } \\
(0.20)\end{array}$ & $\begin{array}{c}\mathbf{- 3 3 . 0 4} * * * \\
(2.40)\end{array}$ \\
\hline Self-Employment $_{t-1}(S E L F)$ & $\begin{array}{c}1.339 * * * \\
(.11)\end{array}$ & $\begin{array}{c}-\mathbf{1 . 4 4 6} \\
(0.71)\end{array}$ & $\begin{array}{c}1.777 * * * \\
(0.07)\end{array}$ & $\begin{array}{c}\text { 3.179**** } \\
(0.46)\end{array}$ \\
\hline Fraud Incidence $_{\mathrm{t}-\mathbf{1}}(C R I M E)$ & $\begin{array}{c}\mathbf{. 0 8 5} \\
(.056)\end{array}$ & $\begin{array}{c}\mathbf{0 . 2 9 6}^{* * *} \\
(0.13)\end{array}$ & $\begin{array}{c}-\mathbf{0 . 0 3 0 6} * \\
(0.02)\end{array}$ & $\begin{array}{c}\mathbf{0 . 1 9 5} * * * \\
(0.03)\end{array}$ \\
\hline Welfare $_{t-1}$ & & & & $\begin{array}{c}\mathbf{0 . 0 2 5 5} \\
(0.10)\end{array}$ \\
\hline Total Expenditure $_{t-1}$ & $\begin{array}{c}\mathbf{0 . 7 9 5} * * * \\
(.27)\end{array}$ & $\begin{array}{c}-\mathbf{4 . 1 7 2} * * * \\
(1.21)\end{array}$ & $\begin{array}{c}-\mathbf{0 . 6 8 6} * * * \\
(0.07)\end{array}$ & \\
\hline Constant & $\begin{array}{c}\mathbf{- 1 2 . 6 2} * * * \\
(2.71) \\
\end{array}$ & $\begin{array}{c}\text { 12.08* } \\
(6.35) \\
\end{array}$ & $\begin{array}{c}-28.87 * * * \\
(0.94) \\
\end{array}$ & $\begin{array}{c}-\mathbf{3 4 . 1 5} \\
(5.11) \\
\end{array}$ \\
\hline Observations & 47 & 46 & 47 & 46 \\
\hline Log Likelihood & 857.13 & 882.85 & 799.44 & 991.23 \\
\hline $\mathrm{X}^{2}$ & 659.97 & 478.94 & 397.19 & 297.79 \\
\hline Trace Statistic 5\% & 2 & 3 & 2 & 2 \\
\hline Max Eigenvalue Statistic 5\% & 2 & 1 & 1 & 1 \\
\hline Lags & 1 & 1 & 4 & 4 \\
\hline \multicolumn{5}{|c|}{$\begin{array}{l}\text { All variables are in natural logs. } \\
\text { Standard Errors presented in parentheses. } \\
*, * *, * * * \text { indicate significance at the } 10,5 \text {, and } 1 \text { percent level respectively. } \\
\text { The number of lags in the models were determined using Akaike's information criterion (AIC), Schwarz's Bayesian information criterion } \\
\text { (SBIC) and the Hannan and Quinn information criterion (HQIC). } \\
\text { asignificant at the } 5 \% \text { level } \\
\text { bignificant tat the } 1 \% \text { level } \\
\text { Source: Own calculations. }\end{array}$} \\
\hline
\end{tabular}




\section{Figure 9:}

Shadow Economy as a percentage of GDP 1970-2015
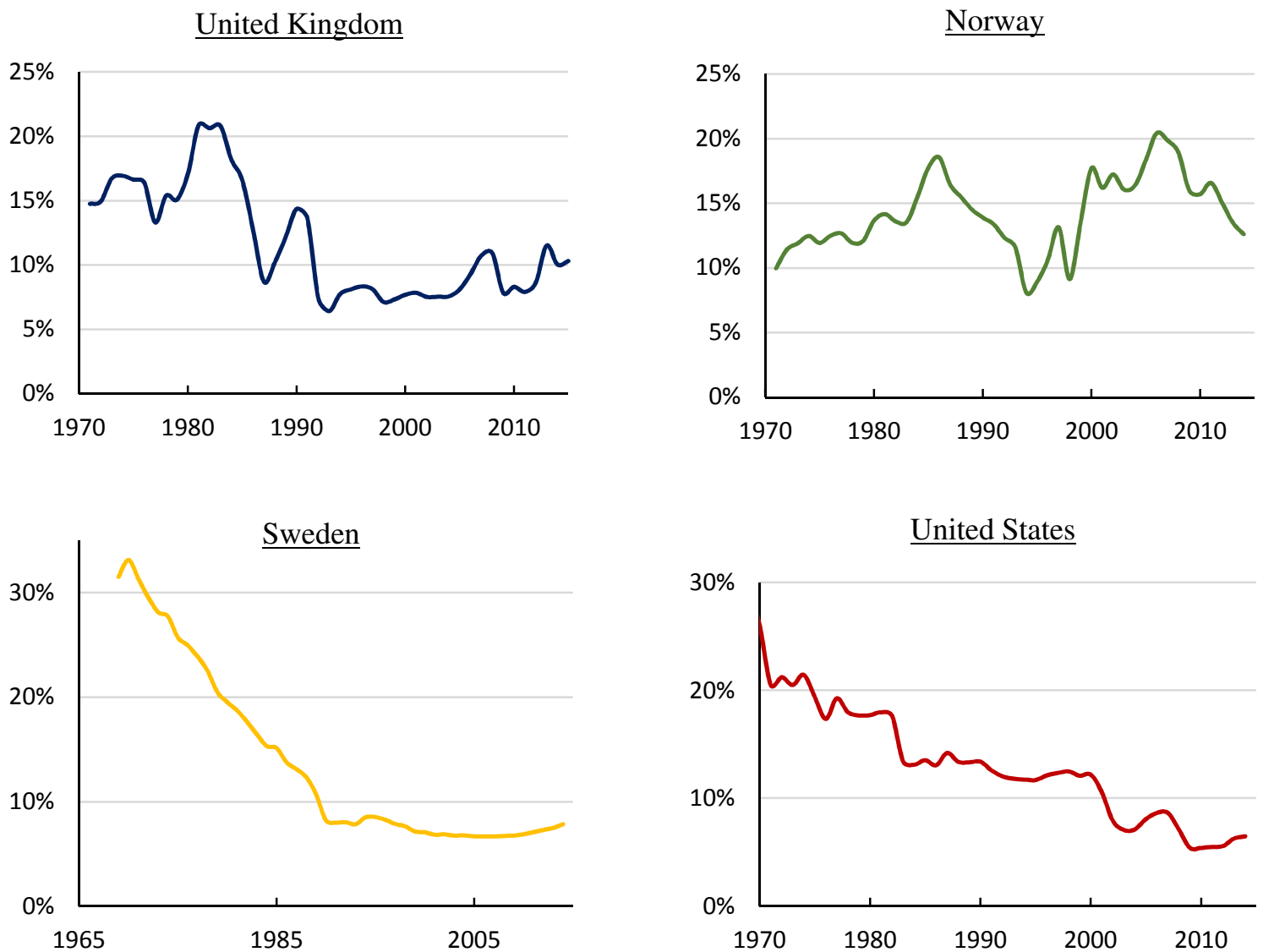

United States

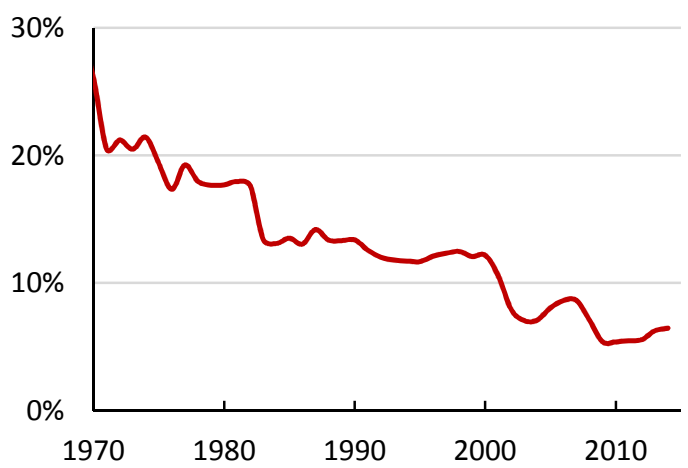

Source: Own Calculations

Figure 10:

Shadow Economies as a percentage of GDP 1970-2015

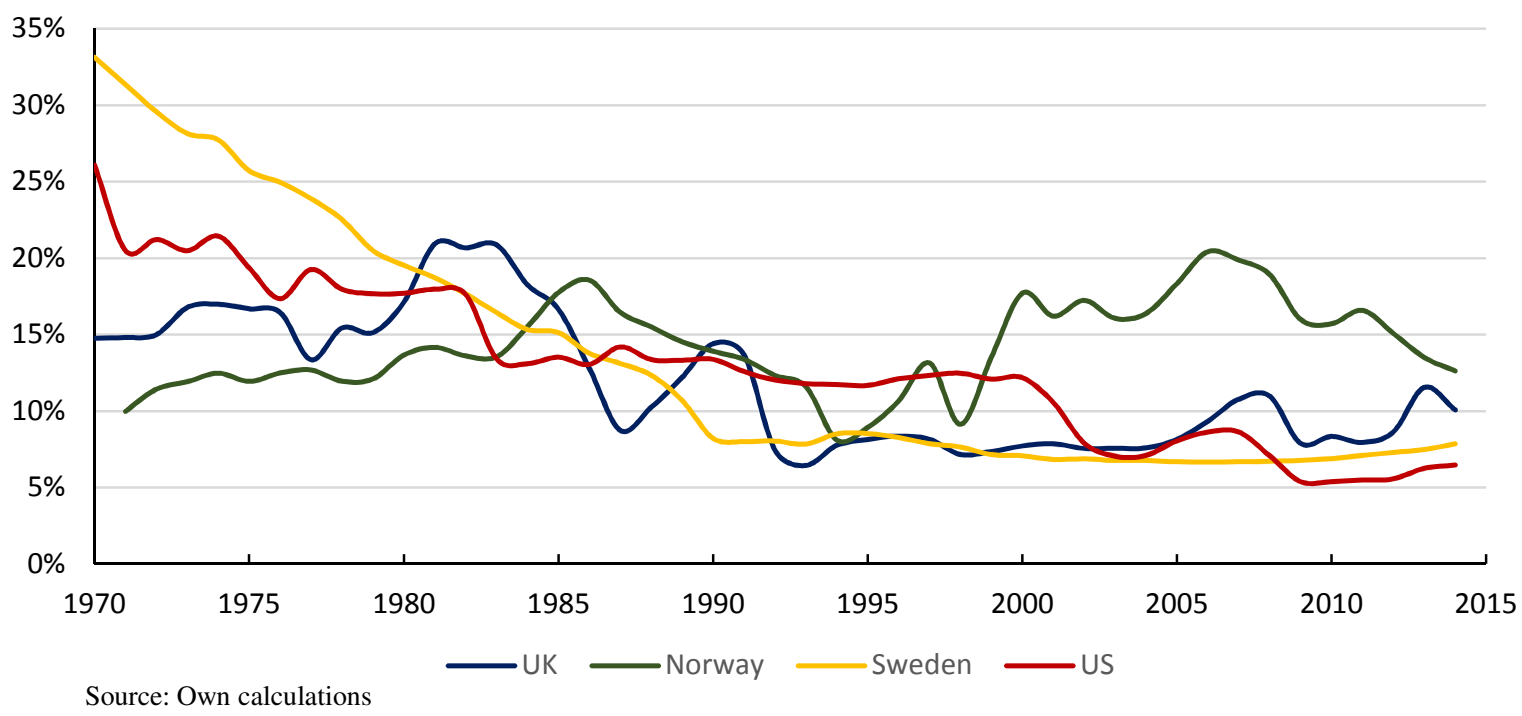




\subsubsection{Estimation Results of the Shadow Economy over 1970-2015}

With the exception of Norway, shadow economies in the panel of countries appear to be decreasing. The most pronounced downward trend is in Sweden which had an illegal sector measuring 33 percent of GDP in 1970 that fell to approximately 7-8 percent of GDP in 1990 and has only mildly fluctuated since then. The UK and the US show signs of receding shadow economies also, though a small increase is visible between 2005 and 2010 which can more than likely be attributed to insolvent banks in America which sent shockwaves across the Atlantic in the form of exposure to complex financial instruments. The Norwegian Shadow economy reaches a local high of 20 percent of GDP in 2007 before receding to approximately 14 percent of GDP in 2014. Norway has been shown by Schneider (2005) to have one of the largest shadow economies of European OECD countries and a report by the Norwegian Lawyers Association (2015) has found that the Norwegian Shadow Economy was the second largest in Europe, at approximately $15 \%$ of GDP, equating to an additional NOK 420 billion in circulation.

\subsection{Limitations of our results}

\section{$\underline{\text { 4.4.1 Dollarization }}$}

One may wonder about the effects of "dollarization" in the panel of countries during the time period at hand, that it the use of dollars instead of the national currency in the country at that time.

Dollarization was largely confined to countries which experienced hyperinflation ${ }^{6}$ and given that none of the countries within the panel experienced hyperinflation (Figure 15) during this period, this can be (largely) ruled out.

\footnotetext{
${ }^{6}$ Hyperinflation as described by Cagan in "The Monetary Dynamics of Hyperinflation" begins in a month where the monthly inflation rate exceeds 50 per cent.
} 


\section{Figure 11:}

Inflation Rates 1860-2015

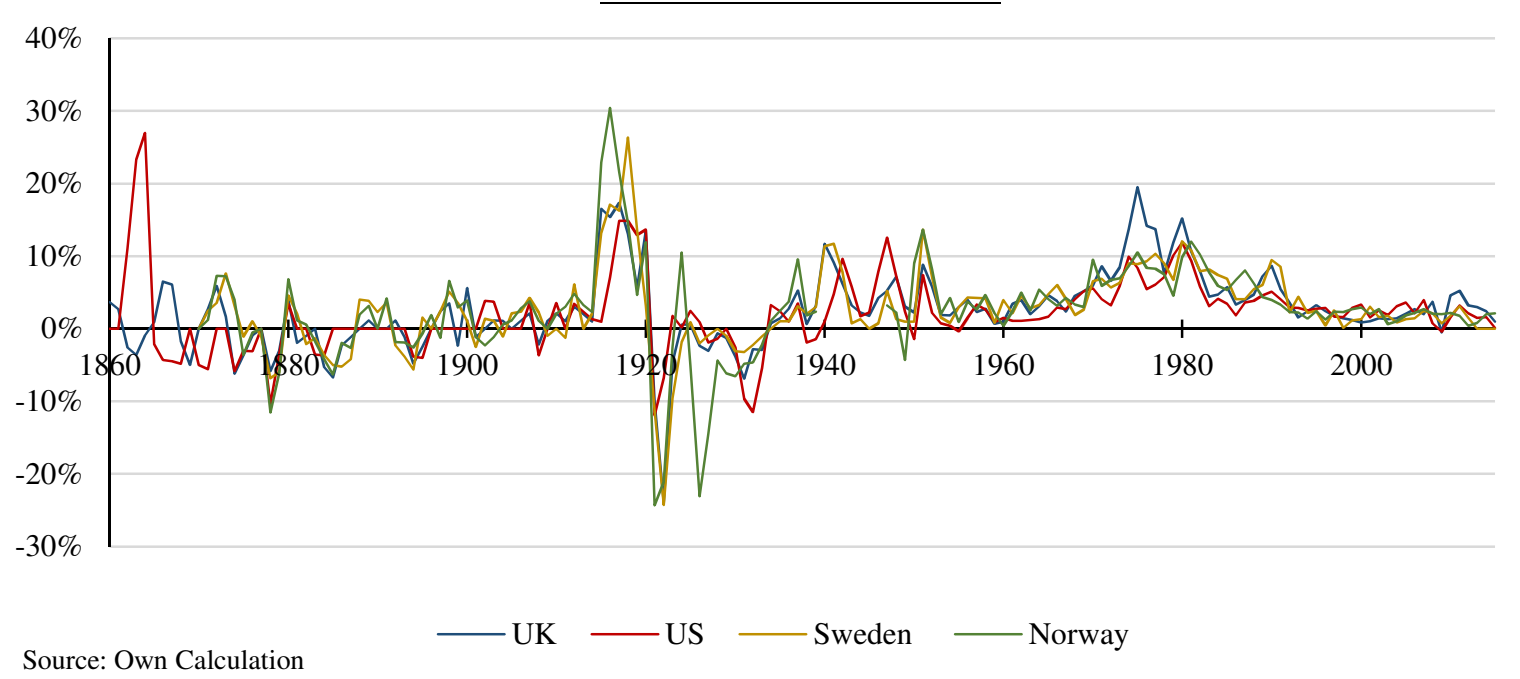

\subsubsection{Comparing Apples and Oranges}

One may be concerned about the differences in variables across different time periods. Can we really compare the size of the shadow economy before the advent of income tax in 1880 , to the shadow economy in 1980 when income taxes are recognised as a man driver or underground activity? In effect, are we comparing apples and oranges? Comparisons across such long periods may be as difficult to compare the results between countries during a particular period. This is one reason why we split up the two periods in the three periods 1870 to 1913, 1914 to 1970 and 1971 to 2015.

\section{$\underline{\text { 4.4.3 Omitted Variables }}$}

While many of the models indicate strong "goodness-of-fit" there may be a problem of omitted variable bias. In the period 1870-1913, data on import tariffs and smuggling could provide more accurate results however these data were not available. Similarly, the period 1970-2015 could've benefitted greatly if it were possible to control for spending with forms of plastic money (credit cards, debit cards) as well as cheques as these forms of payment would decrease the need to hold currency.

\subsubsection{Assumptions of Currency Demand Approach}

There are of course also weaknesses associated with the currency demand approach in modelling the shadow economy. For one, the assumption of a base year without any shadow economic activity is a 
strong assumption. Add to this the fact that not all shadow economic activities are paid for in cash and it is possible that we may be underestimating the size of the shadow economy.

\section{Summary and Conclusions}

\section{"They can't collect legal taxes from illegal money." \\ - Al Capone.(Kobler,1972)}

Shadow economies in the United Kingdom, Norway, Sweden and the United States have experienced wide fluctuations over the past 150 years, from wartime booms to depression lows. One aspect that may bring relief to policymakers is that shadow economies as a percentage of GDP show a pronounced downward trend and less fluctuations than in the pre-World War II period.

In terms of what the future holds for the shadow economy the forecast is rather nebulous. On the one hand the world is become more and more technological. Financial innovation is reducing the need to carry cash, leading to greater accountability of where and in what way individuals spend their money. Electronic footprints make it more difficult for individuals to spend money anonymously. One thing that is for sure is that cash aids and abets the existence of a shadow economy through the anonymity associated with holding it. Large denomination bills are the most widely used in illicit activities (Rogoff, 2014) and the tax burden is believed to be a main driver of underground activity. Whether this result holds in the future is open. Rogoff (2014) argues that the removal of large denomination bills could be more effective than tax reforms in reducing the size of the shadow economy. If this were to occur small denomination notes and coins could remain in circulation to be used for everyday transactions while larger transactions would be carried out electronically. The impracticality of paying for underground goods and services in small denomination notes could potentially disincentivize individuals from participating in the shadow economy. However, as long as the reasons, why people are engaged in shadow economic activities, are not eliminated, the decline in shadow economy will be modest, if only cash is abolished The move towards a cashless society would also mean greater economic control for monetary policy makers, since it would allow central bankers greater scope to make deeper cuts to real interest rates in severe downturns (Rogoff, 2014). 
While the shadow economy looks set to become less of a concern to policymakers there is no cause for celebration just yet. To use a second adage, necessity is the mother of invention. Individuals will always find a way to circumvent rules and regulations if they find them unfavourable. The rise of Bitcoin and The Dark Web facilitate anonymous, illicit transactions online.

One thing that is for sure though is that GDP as a measure of a country's worth is an extremely fickle indicator. It is a blank canvas onto which countries can paint the self-portrait they would like others to see. Countries have incentives to inflate their size of their economies, in addition quashing citizens demands for increased spending by highlighting that their debt-to-GDP is higher than average, countries can also use distorted GDP figures to keep their debt and deficits within prescribed European Union targets. GDP is an all-encompassing figure that includes money spent on activities that generate negative externalities such as pollution, money spent on medical drugs that do not work are also included in GDP but they don't reflect an improvement in national welfare.

In terms of further research on this matter, if a consistent data series on electronic payments could be created it would provide much more accurate estimates of the size of the shadow economy post-1970, as well as attempting to find a better cross-country comparative indicator than GDP.

Finally, while shadow economies are shrinking in size, their decrease may have reached a plateau if not for radical intervention in the form of moves towards a cashless society. A strong and worrying prospect is that shadow economic activity is a cultural phenomenon, depending on nationality. Seen as a victimless crime it is cultured from an "us vs them" siege mentality, deeply embedded in the psyche of the individuals who partake in these activities. Tax reforms and monetary policies are easily adjusted. The recalibration of a moral compass is a much more complex matter. 


\section{REFERENCES:}

Ahumada, H., Alvaredo, F., Canavese, A., \& Paula. C. (2004): The demand for currency approach and the size of the shadow economy: A critical assessment, Discussion Paper, Delta Ecole. Normale Superieure, Paris.

Ahumada, H., Alvaredo, F., \& Canavese, A. (2007). The monetary method and the size of the shadow economy: A critical assessment. Review of Income and Wealth, 53(2), 363-371.

Alañón, A., \& Gómez-Antonio, M. (2005). Estimating the size of the shadow economy in Spain: a structural model with latent variables. Applied Economics, 37(9), 1011-1025

Anderson, R.G., (2003) Some Tables of Historical US Currency and Monetary Aggregates Data. Federal Reserve Bank of St.Louis, Working Paper available at: https://research.stlouisfed.org/wp/2003/2003-006.pdf

Ardizzi, G., Petraglia, C., Piacenza, M., \& Turati, G. (2014). Measuring the Underground Economy with the Currency Demand Approach: A Reinterpretation of the Methodology, With an Application to Italy. Review of Income and Wealth, (4), 747-772.

Bajada, C., \& Schneider, F. (2005b). The shadow economies of the Asia-Pacific. Pacific Economic Review, 10(3), 379-401.

Bhattacharyya, D.K. (1999): On the economic rationale of estimating the hidden economy, The Economic Journal 109/456, pp. 348-359

Bitzenis, A., Vlachos, V., \& Schneider, F., (2016), An Exploration of the Greek Shadow Economy: Can Its Transfer into the Official Economy Provide Economic Relief Amid the Crisis?, Journal of Economic Issues, 50:1.

Buehn, A. (2012). The Shadow Economy in German Regions: An Empirical Assessment. German Economic Review, 13(3), 275-290.

Cagan, P., (1956) The Monetary Dynamics of Hyperinflation In: Studies in the Quantity Theory of Money, ed. by Friedman, M., pp. 25-117, University of Chicago Press, Chicago and London

Cagan, P. (1958). The Demand for Currency Relative to the Total Money Supply. Journal of Political Economy, 66, 1-33

Capie, F., \& Webber, A., (2005) A Monetary History of the United Kingdom: 1870-1982, Data, methods and sources., 3rd edn., London: Routledge.

Christoffersen, P.F., \& Diebold, (1998) F.X.,, Cointegration and Long-Horizon Forecasting, Journal of Business \& Economic Statistics, Vol. 16, No. 4 pp. 450-458

Colombo, E., Onnis, L., \& Tirelli, P. (2016) Shadow economies at times of banking crises: Empirics and theory, Journal of Banking and Finance, 62 (1) pp 34-51.

Dell'Anno, R., (2003): Estimating the shadow economy in Italy: A structural equation approach, Discussion Paper, Department of Economics and Statistics, University of Salerno.

Dell'Anno, R., Gómez-Antonio, M., \& Pardo, A. (2007). The shadow economy in three Mediterranean countries: France, Spain and Greece. A MIMIC approach. Empirical Economics, 33, 51-84.

Eichengreen, B., (1992) Golden fetters: The gold standard and the great depression, New York: Oxford University Press.

Eitrheim, Ø , Klovland J.T, \& Qvigstad F.S (2003) "Historical Monetary Statistics for Norway 18192003" Norgesbank Occasional Paper No.35 
Falck,S., Von Hofer, H., \& Storgaard, A., (2015) Nordic Criminal Statistics 1950-2015, Stockholm: Stockholm University Press.

Feige, E. (1979). How Big is the Irregular Economy?. Challenge,22(1)

Feige, Edgar L. (1989) (ed.): The Underground Economies. Tax Evasion and Information Distortion. Cambridge, New York, Melbourne, Cambridge University Press.

Feld, L. P. and Schneider, F. (2010), Survey on the shadow economy and undeclared earnings in OECD countries, German Economic Review, 11/2, pp. 109-49.

Fishback, P.V., (2010) 'Social Welfare Expenditures in the United States and the Nordic Countries: 1900-2003', NBER Working Paper No. 15982, http://www.nber.org/papers/w15982

Fleming, M.H.; Roman, J \& Farrel, G., (2000): The shadow economy, Journal of International Affairs, Spring 2000, No. 53/2, pp.64-89.

Franz, A. (1983): Wie groß ist die "schwarze" Wirtschaft?, Mitteilungsblatt der Österreichischen Statistischen Gesellschaft, 49/1, pp. 1-6. in: Schneider, F. (2005a). Shadow economies around the world: What do we really know? European Journal of Political Economy, 21(3), 598-642.

Frey, B. S., \& Weck-Hanneman, H. (1984). The hidden economy as an "unobserved" variable. European Economic Review, 26(1-2), 33-53

Friedman, E., Johnson, S., Kaufmann, D. and Zoido-Labton, P. (2000): Dodging the grabbing hand: The determinants of unofficial activity in 69 countries, Journal of Public Economics, 76/4, pp.459493.

Giles, D. (1999a). Measuring the Hidden Economy: Implications for Econometric Modelling. The Economic Journal, 109(456): 370-380.

Giles, D., Tedds, L.M., \& Werkneh, G. (2002): The Canadian underground and measured economies, Applied Economics, 34/4, pp.2347-2352.

Gutmann, P. M. (1977). The Subterranean Economy. Financial Analysts Journal, 33(6), 25-34.

Guibord, G., \& Segendorf, B.L., (2007) The Use of Cash and the Size of the Shadow Economy in Sweden, Riksbank, Research paper Series No. 204. Available at SSRN: http://ssrn.com/abstract=1022024 orhttp://dx.doi.org/10.2139/ssrn.1022024

Hassan, M. \& Schneider, F. (2016) 'Modelling the Egyptian Shadow Economy: A Currency Demand and A MIMIC model approach', Preliminary Draft (available on request).

Hernandez, M. A. (2009). Estimating the size of the hidden economy in Peru: A currency demand approach. Revista de Ciencias Empresariales Y Economia, (8), 85-104.

Hilson, M. (2008) The Nordic Model, Scandinavia since 1945, 2nd edn., London: Reaktion Books.

Isachsen, A. J., \& Strøm, S. (1985). The size and growth of the hidden economy In Norway. Review of Income and Wealth, 31(1), 21-38.

Johnson, S., Kauffman, D,. \& Zoido-Lobaton, P. (1997). Regulatory Discretion and the Unofficial Economy. American Economic Review Papers and Proceedings, 88(2), 387-393

Johnson, S., Kaufmann, D. \& Zoido-Lobatón, P. (1998a). Regulatory Discretion and the Unofficial Economy. The American Economic Review, 88(2): 387-392.

Johnson, S., Kaufmann, D. \& Zoido-Lobatón, P. (1998b). Corruption, Public Finances and the Unofficial Economy. Washington, D.C.: The World Bank, Discussion Paper 
Kaufmann, D. \& Kaliberda, A. (1996). Integrating the Unofficial Economy into the Dynamics of Post Socialist Economies: A framework of Analyses and Evidence. In: B. Kaminski (ed.), Economic Transition in Russia and the New States of Eurasia, London: M.E. Sharpe, pp.81-120.

Klovland, J. T. (1983). The Demand for Money in Secular Perspective. The Case of Norway, 18671980. European Economic Review, 21, 193-218

Klovland, J. T. (1984). Tax evasion and the demand for currency in Norway and Sweden: Is there a hidden relationship? Scandinavian Journal of Economics, 86:4, pp. 423-39.

Kobler, J., (1971) Capone: The life and world of Al Capone, New York: Putnam.

Lackó Mária (1996): Hidden economy in East-European countries in international comparison, Laxenburg: International Institute for Applied Systems Analysis (IIASA), working paper.

Lackó Mária (1998): The hidden economies of Visegrad countries in international comparison: A household electricity approach, In: Halpern, L. and Wyplosz, Ch. (eds.), Hungary: Towards a market economy, Cambridge (Mass.): Cambridge University Press, p.128-152.

Lippert, O. \& Walker, M. (eds.) (1997). The Underground Economy: Global Evidences of its Size and Impact. Vancouver, B.C.: The Frazer Institute

Loayza, N.V., (1996). "he Economics of the Informal Sector: A Simple Model and Some Empirical Evidence from Latin America," Carnegie-Rochester Conference Series on Public Policy, Elsevier, vol. 45(1), pp.129-162

Macias, J. B., \& Cazzavillan, G. (2009). The dynamics of parallel economies. Measuring the informal sector in Mexico. Research in Economics, 63(3), 189-199

Minstry, R., (2001) Family Matters, London: McClelland and Stewart

Mitchell, B.R. (2003) International Historical Statistics: Europe, 1750-2000 , 5th edn., Basingstoke: Palgrave Macmillan.

Mummert, A., \& Schneider, F. (2001): The German shadow economy: Parted in a united Germany?, Finanzarchiv, 58/3, pp.260-285

O'Higgins, M (1989): Assessing the underground economy in the United Kingdom, in: Feige, E.L. (ed.): The underground economies: tax evasion and information distortion, Cambridge: Cambridge University Press, pp. 175-195

Orkent, D., (2010) Last Call: The Rise and Fall of Prohibition, New York: Scribner.

Piketty, T., \& Goldhammer, A. (2014). Capital in the twenty-first century. Cambridge Massachusetts: The Belknap Press of Harvard University Press.

Rogoff, K., (2014) Costs and benefits to phasing out paper currency, Harvard University: Harvard University Press.

Rose, R., (1985) Public Employment in Western Nations, London: Cambridge University Press.

Schneider, F. (1986). Estimating the size of the Danish shadow economy using the currency demand approach: An attempt. The Scandinavian Journal of Economics, 88(4), 643-668.

Schneider, F. (1994a). Measuring the Size and Development of the Shadow Economy. Can the Causes be Found and the Obstacles be Overcome? Brandstaetter, Hermann, and Güth, Werner (eds.): Essays on Economic Psychology, Berlin, Heidelberg, Springer Publishing Company, pp. 193-212.

Schneider, F. (1994b). Can the Shadow Economy be Reduced through Major Tax Reforms? An Empirical Investigation for Austria. Supplement to Public Finance/ Finances Publiques 49: 137-152. 
Schneider, F. (1997). The Shadow Economies of Western Europe. Journal of the Institute of Economic Affairs, 17(3): 42-48.

Schneider, F. (1998a). Further Empirical Results of the Size of the Shadow Economy of 17 OECDCountries over Time. Paper to be presented at the 54. Congress of the IIPF Cordowa, Argentina and discussion paper, Department of Economics, University of Linz, Linz, Austria.

Schneider, F. (2000a). Dimensions of the Shadow Economy. Independent Review, 5(1), 81-91.

Schneider, F. (2000b). The Increase of the Size of the Shadow Economy of 18 OECD-Countries: Some Preliminary Explanations. Paper presented at the Annual Public Choice Meeting, March 10-12, 2000, Charleston, S.C.

Schneider, F., \& Enste, D. H. (2000). Shadow Economies: Size, Causes, and Consequences. Journal of Economic Literature, 38(1), 77-114.

Schneider, F. and Enste, D. (2002). The Shadow Economy: Theoretical Approaches, Empirical Studies, and Political Implications. Cambridge (UK): Cambridge University Press.

Schneider, F. (2003). The Shadow Economy. In: Charles K. Rowley and Friedrich Schneider (eds.), Encyclopedia of Public Choice, Kluwer Academic Publishers, Dordrecht.

Schneider, F. (2005a). Shadow economies around the world: What do we really know? European Journal of Political Economy, 21(3), 598-642.

Schneider, F. and Buehn, A. (2009). Shadow Economies and Corruption All Over the World: Revised Estimates for 120 Countries. Economics: The Open-Access, Open-Assessment E-Journal, 1, 2007-9.

Schneider, F., Buehn, A., \& Montenegro, C. E. (2010). New Estimates for the Shadow Economies all over the World. International Economic Journal, 24(4), 443-461.

Schneider, F. \& Buehn, M., (2016) Estimating the Size of the Shadow Economy: Methods, Problems and Open Questions. IZA Discussion Paper No. 9820

Schneider, F. (2016) "The Morals Of (Not) Paying Taxes And Receiving Benefits: What Have We Learned Over The Past 20 Years?". 2016. Presented at Queen's Management School, Queen's University Belfast.

Schneider, Friedrich and Collin C. Williams (2013), The Shadow Economy, London Institute of Economic Affairs.

Schularick, M. \& Taylor, A.M. (2012) 'Credit Booms Gone Bust: Monetary Policy, Leverage Cycles, and Financial Crises, 1870-2008', American Economic Review, 102(2), pp. 1029-1061.

Stenkula M., Johansson, D., \& Du Rietz, G. (2014) Marginal taxation on labour income in Sweden from 1862 to 2010, Scandinavian Economic History Review, 62:2, 163-187.

Tanzi, V. (1980): The underground economy in the United States: Estimates and implications, Banca Nazionale del Lavoro, 135:4, pp. 427-453

Tanzi, V. (1983). The underground economy in the United States: annual estimates, 1930-80. Staff Papers - International Monetary Fund, 30(2), 283-305.

Tanzi, V. (1999). Uses and abuses of estimates of the underground economy. The Economic Journal, 109(456), 338-347.

Tanzi, V. \& Schuknecht, L., (2000) Public Spending in the 20th Century: A Global Perspective Lugder, V. (2000), New York: Cambridge University Press

Thomas, J. J. (1986). The Underground Economy in the United States: A Comment on Tanzi. IMFStaff Papers, Vol. 33(4): 782-789. 
Thomas, Jim J. (1992): Informal Economic Activity, LSE, Handbooks in Economics, London: Harvester Wheatsheaf.

Universities-National Bureau (1958) The Measurement and Behavior of Unemployment, New York: http://www.nber.org/books/univ57-1.

Vitaliano, D. F. (2015), Repeal of Prohibition: A Benefit-Cost Analysis. Contemp Econ Policy, 33: $44-55$.

Von Hoffer, H., (2011), Punishment and Crime in Scandanaavia 1750-2008, in: Crime and Justice in Scandanavia, Tonry, M., \& Lappi-Sepalla, T., Vol.40 of Crime and Justice: A review of Research. Chicago, University of Chicago Press.

Williams, C.C. \& Schneider, F. (2016): Measuring the Global Shadow Economy: The Prev-alence of Informal Work and Labour, Edward Elgar Publishing Company, Cheltenham (UK)/Northampton (MA).

Williamson, S.H (2016) "What Was the U.S. GDP Then?" MeasuringWorth, URL: http://www.measuringworth.com/usgdp/

Williamson, S.H (2016) "What Was the U.K. GDP Then?" MeasuringWorth, URL: http://www.measuringworth.com/ukgdp/

Woodiwiss, M., (1988) Crime, Crusades, and Corruption: Prohibitions in the United States, 19001987, London: Pinter Publishers.

World Bank. (2009). Banking the poor : measuring banking access in 54 economies. Washington, DC: World Bank. http://documents.worldbank.org/curated/en/608761468157765351/Banking-thepoor-measuring-banking-access-in-54-economies 
APPENDIX A: Detailed Results - United Kingdom

All calculations are authors own unless otherwise stated:

Table A1: Shadow Economy estimates 1884-2015.

(1) Size of the shadow economy as a percentage of GDP

(2) The monetary value of the shadow economy in real terms (2012 prices)

(1) (2)

$$
\begin{array}{ccc}
\text { Year } & \text { \% of GDP } & \mathbb{1} \text { mn } \\
\mathbf{1 8 8 4} & 16.8 \% & 22,323 \\
\mathbf{1 8 8 5} & 13.8 \% & 18,211 \\
\mathbf{1 8 8 6} & 13.6 \% & 18,027 \\
\mathbf{1 8 8 7} & 13.6 \% & 18,814 \\
\mathbf{1 8 8 8} & 13.7 \% & 19,517 \\
\mathbf{1 8 8 9} & 14.0 \% & 20,601 \\
\mathbf{1 8 9 0} & 22.5 \% & 33,429 \\
\mathbf{1 8 9 1} & 22.5 \% & 34,248 \\
\mathbf{1 8 9 2} & 23.2 \% & 34,540 \\
& 221 \% &
\end{array}
$$$$
\begin{array}{lll}
\mathbf{1 8 9 3} & 22.1 \% & 34,540 \\
& & 32,750
\end{array}
$$$$
\mathbf{1 8 9 4} 21.1 \% \quad 32,684
$$$$
\mathbf{1 8 9 5} \quad 19.8 \% \quad 31,760
$$$$
1896 \quad 21.3 \% \quad 35,561
$$$$
\mathbf{1 8 9 7} \quad 24.6 \% \quad 41,476
$$$$
\begin{array}{lll}
\mathbf{1 8 9 7} & 24.6 \% & 41,476 \\
\mathbf{1 8 9 8} & 24.3 \% & 42,908
\end{array}
$$$$
\begin{array}{lll}
\mathbf{1 8 9 8} & 24.3 \% & 42,908 \\
\mathbf{1 8 9 9} & 23.2 \% & 42,406
\end{array}
$$$$
1900 \quad 24.2 \% \quad 44,120
$$$$
1901 \quad 23.6 \% \quad 43,890
$$$$
1902 \quad 22.3 \% \quad 42,015
$$$$
\mathbf{1 9 0 3} \quad 22.9 \% \quad 42,827
$$$$
\begin{array}{lll}
\mathbf{1 9 0 4} & 22.9 \% & 43,253 \\
\mathbf{1 9 0 5} & 23.2 \% & 45,231
\end{array}
$$$$
\begin{array}{lll}
\mathbf{1 9 0 5} & 23.2 \% & 45,231 \\
\mathbf{1 9 0 6} & 23.4 \% & 46,666
\end{array}
$$$$
\begin{array}{lll}
\mathbf{1 9 0 6} & 23.4 \% & 46,666 \\
\mathbf{1 9 0 7} & 23.5 \% & 47,810
\end{array}
$$$$
\begin{array}{lll}
1907 & 23.5 \% & 47,810 \\
\mathbf{1 9 0 8} & 23.1 \% & 45,265
\end{array}
$$$$
\begin{array}{lll}
\mathbf{1 9 0 8} & 23.1 \% & 45,265 \\
\mathbf{1 9 0 9} & 23.7 \% & 47,574
\end{array}
$$$$
\begin{array}{lll}
\mathbf{1 9 0 9} & 23.7 \% & 47,574 \\
\mathbf{1 9 1 0} & 24.5 \% & 50,287
\end{array}
$$$$
1911 \quad 21.7 \% \quad 46,168
$$$$
\begin{array}{lll}
\mathbf{1 9 1 1} & 21.7 \% & 46,168 \\
\mathbf{1 9 1 2} & 21.4 \% & 46,140
\end{array}
$$$$
1913 \quad 19.7 \% \quad 44,106
$$$$
1914 \quad 23.1 \% \quad 52,852
$$$$
1915 \quad 44.3 \% \quad 106,920
$$$$
1916 \quad 37.8 \% \quad 92,309
$$$$
\mathbf{1 9 1 7} \quad 35.0 \% \quad 84,881
$$$$
1918 \quad 25.8 \% \quad 63,719
$$$$
1919 \quad 23.1 \% \quad 52,665
$$$$
1920 \quad 23.4 \% \quad 50,107
$$

(1)

(1)

(1)

(2)

$\begin{array}{llllll}\text { Year } & \begin{array}{c}\text { \% of } \\ \text { GDP }\end{array} & £ \text { mn } & \text { Year } & \begin{array}{l}\text { \% of } \\ \text { GDP }\end{array} & £ \text { mn } \\ \mathbf{1 9 5 8} & 30.2 \% & 132,993 & \mathbf{1 9 9 5} & 8.1 \% & 95,750\end{array}$

1921

GDP $\quad £$ mn

$26.2 \% \quad 48,929$

1922

$30.4 \% \quad 59,634$

1923

$26.6 \%$

53,703

1924

$28.2 \% \quad 59,735$

$32.2 \% \quad 70,501$

$32.1 \% \quad 68,261$

1926

1927

$32.0 \%$

73,209

1928

$31.7 \% \quad 73,240$

1929

$32.4 \%$

76,820

1930

$28.1 \%$

66,059

1931

$30.3 \%$

68,021

1932

$30.7 \%$

68,998

1933

$28.0 \%$

64,999

1934

$23.0 \%$

56,592

$23.1 \% \quad 58,716$

1935

$18.7 \%$

1937

1938

$25.6 \%$

49,987

1939

$22.0 \%$

70,806

61,174

$18.6 \%$

53,951

1940

$26.6 \%$

84,995

1941

$31.2 \%$

108,254

1942

$28.2 \%$

99,661

1943

$26.0 \%$

93,490

1944

$24.0 \%$

82,488

1945

$14.8 \%$

48,540

1946

$18.4 \%$

58,996

1947

1948

$15.9 \%$

50,095

$14.0 \% \quad 45,792$

1949

$12.5 \% \quad 41,976$

$11.1 \% \quad 38,714$

1950

1951

$26.5 \%$

1952

$26.7 \%$

1953

$24.3 \%$

1954

$26.6 \%$

1955

$34.1 \%$

1956

$32.6 \%$

1957

$30.9 \%$

95,772

98,011

94,277

107,259

143,097

138,916

134,374
195

1959

1960

1961

1962

1963

1964

1965

1966

1967

1968

1969

1970

1971

1972

1973

1974

1975

1976

1977

1978

1979

1980

1981

1982

1983

1984

1985

1986

1987

1988

1989

1990

$1991 \quad 13.7 \% \quad 146,312$

$1992 \quad 7.4 \% \quad 80,059$

$1993 \quad 6.4 \% \quad 71,021$

$1994 \quad 7.8 \% \quad 89,008$
(1)

(2)

5,750

$1996 \quad 8.4 \% \quad 101,002$

$1997 \quad 8.1 \% \quad 101,465$

$1998 \quad 7.2 \% \quad 92,084$

$1999 \quad 7.4 \% \quad 97,577$

$2000 \quad 7.7 \% \quad 106,244$

$2001 \quad 7.9 \% \quad 111,341$

$2002 \quad 7.5 \% \quad 109,503$

$2003 \quad 7.6 \% \quad 113,485$

$2004 \quad 7.6 \% \quad 116,592$

$2005 \quad 8.1 \% \quad 128,779$

$2006 \quad 9.3 \% \quad 151,663$

$\mathbf{2 0 0 7} 10.8 \% \quad 179,632$

$2008 \quad 11.0 \% \quad 182,020$

$2009 \quad 7.9 \% \quad 125,289$

$2010 \quad 8.3 \% \quad 134,591$

$20117.9 \% \quad 130,703$

$2012 \quad 8.6 \% \quad 143,837$

$2013 \quad 11.5 \% \quad 196,451$

$2014 \quad 10.1 \% \quad 176,296$

$2015 \quad 10.3 \% \quad 185,269$ 
Table A2: Definition of Monetary Aggregates:

\begin{tabular}{|c|l|}
\hline & \multicolumn{1}{c|}{ United Kingdom } \\
\hline Variable & Definition \\
\hline M0 & Notes and coins in circulation with the non-bank public. \\
\hline M1 & $\begin{array}{l}\text { M0 plus sterling current accounts held by the private sector only, excluding those held } \\
\text { by the public and overseas sector. }\end{array}$ \\
\hline M2 & M1 plus time deposit accounts of private sector UK residents with deposit banks. \\
\hline M3 & $\begin{array}{l}\text { Non-bank holdings of notes and coins plus all deposits of all residents (both private and } \\
\text { public sectors) with the UK banking sector including sight and time deposits in sterling } \\
\text { and foreign currency, and time deposits with accepting houses, overseas bank and other } \\
\text { banks). }\end{array}$ \\
\hline
\end{tabular}

Table A3: Data Sources:

\begin{tabular}{|c|c|c|c|}
\hline \multirow[b]{3}{*}{ Variable: } & \multicolumn{3}{|c|}{ United Kingdom } \\
\hline & 1880-1913 & 1913-1970 & 1970-2015 \\
\hline & & & \\
\hline \multicolumn{4}{|l|}{ Monetary Aggregates } \\
\hline GDP & \multicolumn{3}{|c|}{$\begin{array}{l}\text { Samuel H. Williamson, "What Was the U.K. GDP Then?" MeasuringWorth, } 2016 \\
\text { URL: http://www.measuringworth.com/ukgdp/ }\end{array}$} \\
\hline Interest Rate & \multicolumn{3}{|c|}{ Schularick and Taylor (2012) supplemented by Bank of England data } \\
\hline Tax Burden & $\begin{array}{l}\text { Mitchell International } \\
\text { Historical Statistics, } \\
\text { Europe } 1750-2000\end{array}$ & $\begin{array}{c}\text { Piketty, Thomas, "Capital in } \\
\text { the } 21 \text { st Century, Harvard } \\
\text { University Press", } 2014\end{array}$ & $\begin{array}{l}\text { OECD } \\
\text { https://data.oecd.org/tax/tax- } \\
\text { revenue.htm\#indicator-chart }\end{array}$ \\
\hline Self-Employment Rate & & Office of National Statistics & OECD \\
\hline Unemployment Rate & & $\begin{array}{l}\text { Office of National Statistics, } \\
\text { Denman (1996) }\end{array}$ & OECD \\
\hline $\begin{array}{l}\text { Total Government } \\
\text { Expenditure }\end{array}$ & \multicolumn{3}{|c|}{ https://www.UKpublicspending.com } \\
\hline $\begin{array}{l}\text { Total Welfare } \\
\text { Expenditure }\end{array}$ & \multicolumn{3}{|c|}{ https://www.UKpublicspending.com } \\
\hline Size of Public Sector & & & OECD \\
\hline Fraud Incidence & & \multicolumn{2}{|c|}{ https://www.gov.uk/government/statistics/historical-crime-data } \\
\hline $\begin{array}{l}\text { Wages and Salaries in } \\
\text { national Income }\end{array}$ & \multicolumn{3}{|c|}{ National Archives, Office of National Statistics } \\
\hline
\end{tabular}


Table A4: Unit Root Test:

\begin{tabular}{|c|c|c|c|c|c|c|}
\hline \multirow[b]{3}{*}{ Variable } & \multicolumn{6}{|c|}{ United Kingdom 1913-1970 } \\
\hline & \multicolumn{3}{|c|}{ At Level } & \multicolumn{3}{|c|}{ First Difference } \\
\hline & Intercept & $\begin{array}{l}\text { Trend } \\
\text { and } \\
\text { Intercept }\end{array}$ & $\begin{array}{l}\text { No Trend } \\
\text { No } \\
\text { Intercept }\end{array}$ & Intercept & $\begin{array}{l}\text { Trend and } \\
\text { Intercept }\end{array}$ & $\begin{array}{l}\text { No Trend No } \\
\text { Intercept }\end{array}$ \\
\hline $\mathrm{C} / \mathrm{M} 2$ & -1.726 & -1.078 & 0.346 & $-7.091 * * *$ & $-7.261 * * *$ & $-7.127 * * *$ \\
\hline $\mathbf{Y}$ & 1.247 & -1.161 & $1.949 *$ & $-5.089 * * *$ & $-5.260 * * *$ & $-4.403 * * *$ \\
\hline $\mathbf{R}$ & 0.230 & -0.359 & 1.662 & $-6.070 * * *$ & $-6.174 * * *$ & $-5.913 * * *$ \\
\hline Tax & -2.126 & -1.411 & 0.885 & $-4.430 * * *$ & $-4.544 * * *$ & $-4.322 * * *$ \\
\hline UNEMP & -2.123 & -2.066 & -1.923 & $-6.438 * * *$ & $-6.386 * * *$ & $-6.494 * * *$ \\
\hline WELFARE & -1.396 & -2.035 & 0.496 & $-4.771 * * *$ & $-4.721 * * *$ & $-4.734 * * *$ \\
\hline REG & -1.967 & -1.726 & 0.920 & $-1.967 * * *$ & $-1.726 * * *$ & $0.920 * * *$ \\
\hline FRAUD & -1.028 & -1.248 & -0.313 & $-2.028 * *$ & $-2.248 * *$ & $-0.313 * *$ \\
\hline
\end{tabular}

\begin{tabular}{|c|c|c|c|c|c|c|}
\hline \multirow[b]{3}{*}{ Variable } & \multicolumn{6}{|c|}{ United Kingdom 1970-2015 } \\
\hline & \multicolumn{3}{|c|}{ At Level } & \multicolumn{3}{|c|}{ First Difference } \\
\hline & Intercept & $\begin{array}{l}\text { Trend } \\
\text { and } \\
\text { Intercept }\end{array}$ & $\begin{array}{l}\text { No Trend } \\
\text { No } \\
\text { Intercept }\end{array}$ & Intercept & $\begin{array}{l}\text { Trend and } \\
\text { Intercept }\end{array}$ & $\begin{array}{l}\text { No Trend No } \\
\text { Intercept }\end{array}$ \\
\hline $\mathrm{C} / \mathrm{M} 2$ & -0.617 & -0.931 & $2.476 * *$ & $-4.788 * * *$ & $-4.742 * * *$ & $-4.353 * * *$ \\
\hline $\mathbf{Y}$ & -0.875 & -2.695 & $4.903 * * *$ & $-7.440 * * *$ & $-7.431 * * *$ & $-5.152 * * *$ \\
\hline $\mathbf{R}$ & -0.936 & -2.973 & -0.751 & $-7.250 * * *$ & $-7.662 * * *$ & $-7.210 * * *$ \\
\hline Tax & $-2.997 *$ & $-3.508 *$ & $2.024 * *$ & $-5.303 * * *$ & $-5.336 * * *$ & $-5.084 * * *$ \\
\hline REG & $-2.661 *$ & -1.751 & 0.222 & $-5.656 * * *$ & $-6.049 * * *$ & $-5.717 * * *$ \\
\hline SELF & -1.411 & -1.097 & $2.060 * *$ & $-5.568 * * *$ & $-5.640 * * *$ & $-5.167 * * *$ \\
\hline TOTEXP & -1.703 & -1.772 & 0.114 & $-4.925 * * *$ & $-4.871 * * *$ & $-4.979 * * *$ \\
\hline FRAUD & -1.427 & -0.924 & -0.293 & $-4.115^{* * *}$ & $-4.157 * *$ & $-4.157^{* * *}$ \\
\hline
\end{tabular}

Reported above are the T-statistics for the Augmented Dicky-Fuller (ADF) test.

Null hypothesis: variable has unit root.

The lag length was chosen using the Schwarz Information Criterion.

$*, * *, * * *$ indicate significance at the 10,5 , and 1 percent level respectively.

Source: Own calculations 
Table A5: Stability Analysis:

\begin{tabular}{|c|c|c|c|c|c|c|}
\hline \multirow[b]{3}{*}{ Dependent Variable } & \multicolumn{6}{|c|}{ Cointegrating Coefficients United Kingdom } \\
\hline & \multicolumn{3}{|c|}{ 1913-1970 } & \multicolumn{3}{|c|}{$1970-2015$} \\
\hline & $\mathrm{C}$ & $\mathrm{C} / \mathrm{M} 1$ & $\mathrm{C} / \mathrm{M} 1$ & $\mathrm{C} / \mathrm{M} 1$ & $\mathrm{C} / \mathrm{M} 2$ & $\mathrm{C} / \mathrm{M} 2$ \\
\hline C/M1 & 1.00 & 1.00 & 1.00 & 1.00 & 1.00 & 1.00 \\
\hline $\begin{array}{l}\text { Y/capita (real } \\
\text { income/capita) }\end{array}$ & $\begin{array}{c}\mathbf{3 . 4 1 0} * * * \\
(1.01)\end{array}$ & & & & $\begin{array}{c}-\mathbf{0 . 6 1 1} * * * \\
(.12)\end{array}$ & \\
\hline $\mathbf{Y}$ (real income) & & $\begin{array}{c}\mathbf{- 5 . 4 5 9} * * * * \\
(1.86)\end{array}$ & $\begin{array}{c}\mathbf{- 0 . 1 3 6} \\
(.67)\end{array}$ & $\begin{array}{c}1.406 * * * \\
(.25)\end{array}$ & & $\begin{array}{c}1.330 * * * \\
(.45)\end{array}$ \\
\hline $\mathbf{R}$ (interest rate) & $\begin{array}{c}1.921 * * * \\
(.42)\end{array}$ & $\begin{array}{c}\mathbf{- 0 . 4 8 9} * * * \\
(.12)\end{array}$ & $\begin{array}{c}1.622 * * * \\
(.29)\end{array}$ & $\begin{array}{c}\mathbf{0 . 8 1 9} * * * \\
(.1)\end{array}$ & $\begin{array}{c}\mathbf{- 0 . 4 9 2} * * * \\
(.05)\end{array}$ & $\begin{array}{c}\mathbf{0 . 1 8 5} * * * \\
(.03)\end{array}$ \\
\hline $\begin{array}{l}\text { TAX2 (Top Marginal Tax } \\
\text { Rate) }\end{array}$ & $\begin{array}{l}\mathbf{2 2 . 3 1 *} \\
(11.5)\end{array}$ & $\begin{array}{c}\mathbf{6 2 . 3 6}^{* * * *} \\
(22.8)\end{array}$ & $\begin{array}{c}\text { 36.43*** } \\
(5.53)\end{array}$ & $\begin{array}{l}4.242 * \\
(.34)\end{array}$ & $\begin{array}{c}\mathbf{3 . 3 6 7} * * * \\
(1.27)\end{array}$ & $\begin{array}{c}\mathbf{1 0 . 8 5}^{* *} \\
(5.35)\end{array}$ \\
\hline REG (public employment) & & & $\begin{array}{c}\mathbf{- 5 . 9 9 4} * * * \\
(1.23)\end{array}$ & $\begin{array}{c}-4.080 * * * \\
(.40)\end{array}$ & $\begin{array}{c}1.191 * * * \\
(.24)\end{array}$ & $\begin{array}{c}-\mathbf{6 . 6 6 3} * * * \\
(.80)\end{array}$ \\
\hline SELF (self-employment) & & & $\begin{array}{c}5.729 * * * \\
(.46)\end{array}$ & $\begin{array}{c}1.475^{* * * *} \\
(.13)\end{array}$ & $\begin{array}{c}\mathbf{0 . 8 1 9} * * * \\
(.09)\end{array}$ & $\begin{array}{c}\mathbf{2 . 1 4 1} * * * * \\
(.31)\end{array}$ \\
\hline CRIME (fraud incidence) & & $\begin{array}{c}1.761 * * \\
(.75)\end{array}$ & $\begin{array}{c}1.903 * * * \\
(.18)\end{array}$ & $\begin{array}{c}\mathbf{0 . 1 3 0} * * \\
(.07)\end{array}$ & $\begin{array}{c}\mathbf{0 . 0 0 3 2} \\
(.04)\end{array}$ & $\begin{array}{c}\mathbf{- 0 . 0 6 2 3} \\
(.16)\end{array}$ \\
\hline $\begin{array}{l}\text { SOC (social welfare } \\
\text { expenditure) }\end{array}$ & & $\begin{array}{c}11.33 * * * \\
(2.14)\end{array}$ & $\begin{array}{c}\mathbf{- 5 . 0 7 4} * * * \\
(.70)\end{array}$ & & & \\
\hline $\begin{array}{l}\text { GOV (government } \\
\text { expenditure) }\end{array}$ & & & & $\begin{array}{c}0.980 * * * \\
(.31)\end{array}$ & $\begin{array}{c}\mathbf{- 0 . 5 8 8} * * * \\
(.21)\end{array}$ & $\begin{array}{l}\mathbf{0 . 1 6 6} \\
(.67)\end{array}$ \\
\hline UE (Unemployment rate) & $\begin{array}{c}0.394 * * \\
(.15)\end{array}$ & & & & & \\
\hline Constant & $\begin{array}{c}-42.42 * * * \\
(2.56)\end{array}$ & $\begin{array}{c}38.72 * * * \\
(1.78)\end{array}$ & $\begin{array}{c}1.249 * * * \\
(.07)\end{array}$ & $\begin{array}{c}\mathbf{- 1 4 . 7 8} * * * \\
(2.15)\end{array}$ & $\begin{array}{l}\mathbf{5 . 2 0} * * \\
(1.21)\end{array}$ & $\begin{array}{c}\mathbf{- 5 . 4 7 3} * * * \\
(.86)\end{array}$ \\
\hline Log Likelihood & 180.12 & 218.51 & 178.94 & 225.03 & 166.83 & 245.01 \\
\hline Observations & 58 & 55 & 55 & 50 & 47 & 47 \\
\hline Autocorrelation LM Test & 27.55 & 33.41 & 27.52 & 34.62 & 24.65 & 39.13 \\
\hline Lags & 1 & 4 & 4 & 1 & 4 & 4 \\
\hline
\end{tabular}




\section{Appendix B: Detailed Results - Norway}

Table B1: Shadow Economy estimates 1872-2015.

(1) Size of the shadow economy as a percentage of GDP

(2) The monetary value of the shadow economy (million NOK) in real terms (2005 prices)

\begin{tabular}{|c|c|c|c|c|c|c|c|c|c|c|c|}
\hline Year & $\begin{array}{c}\text { (1) } \\
\% \text { of GDP }\end{array}$ & $\begin{array}{c}\text { (2) } \\
\text { NOK } \\
\text { mn }\end{array}$ & Year & $\begin{array}{c}\text { (1) } \\
\% \text { of GDP }\end{array}$ & $\begin{array}{c}\text { (2) } \\
\text { NOK } \\
\text { mn }\end{array}$ & Year & $\begin{array}{c}\text { (1) } \\
\% \text { of GDP }\end{array}$ & $\begin{array}{c}\text { (2) } \\
\text { NOK mn }\end{array}$ & Year & $\begin{array}{c}\text { (1) } \\
\% \text { of GDP }\end{array}$ & $\begin{array}{c}\text { (2) } \\
\text { NOK } \\
\text { mn }\end{array}$ \\
\hline 1872 & $40.4 \%$ & 15,043 & 1911 & $23.6 \%$ & 18,602 & 1950 & $15.0 \%$ & 38,889 & 1989 & $14.5 \%$ & 177,103 \\
\hline 1873 & $39.1 \%$ & 14,909 & 1912 & $23.1 \%$ & 19,117 & 1951 & $15.5 \%$ & 42,260 & 1990 & $13.9 \%$ & 172,831 \\
\hline 1874 & $36.6 \%$ & 14,483 & 1913 & $23.1 \%$ & 20,155 & 1952 & $15.7 \%$ & 44,533 & 1991 & $13.4 \%$ & 171,423 \\
\hline 1875 & $31.8 \%$ & 12,955 & 1914 & $21.5 \%$ & 19,126 & 1953 & $16.5 \%$ & 49,172 & 1992 & $12.3 \%$ & 163,593 \\
\hline 1876 & $33.9 \%$ & 14,203 & 1915 & $20.5 \%$ & 18,995 & 1954 & $17.3 \%$ & 54,309 & 1993 & $11.6 \%$ & 158,233 \\
\hline 1877 & $36.7 \%$ & 15,482 & 1916 & $18.2 \%$ & 17,513 & 1955 & $16.8 \%$ & 53,754 & 1994 & $8.1 \%$ & 116,269 \\
\hline 1878 & $37.6 \%$ & 15,303 & 1917 & $16.6 \%$ & 14,552 & 1956 & $18.3 \%$ & 61,902 & 1995 & $8.9 \%$ & 133,173 \\
\hline 1879 & $36.1 \%$ & 14,803 & 1918 & $14.4 \%$ & 12,081 & 1957 & $17.8 \%$ & 61,975 & 1996 & $10.7 \%$ & 167,107 \\
\hline 1880 & $36.6 \%$ & 15,509 & 1919 & $14.7 \%$ & 14,465 & 1958 & $17.9 \%$ & 62,220 & 1997 & $13.1 \%$ & 216,981 \\
\hline 1881 & $36.2 \%$ & 15,458 & 1920 & $14.9 \%$ & 15,632 & 1959 & $17.9 \%$ & 65,390 & 1998 & $9.1 \%$ & 154,729 \\
\hline 1882 & $34.3 \%$ & 14,646 & 1921 & $15.1 \%$ & 14,358 & 1960 & $17.7 \%$ & 68,372 & 1999 & $13.5 \%$ & 233,500 \\
\hline 1883 & $33.8 \%$ & 14,382 & 1922 & $16.0 \%$ & 16,772 & 1961 & $17.8 \%$ & 73,429 & 2000 & $17.7 \%$ & 315,850 \\
\hline 1884 & $33.3 \%$ & 14,429 & 1923 & $16.3 \%$ & 17,596 & 1962 & $18.6 \%$ & 79,355 & 2001 & $16.2 \%$ & 295,061 \\
\hline 1885 & $33.5 \%$ & 14,615 & 1924 & $17.0 \%$ & 18,340 & 1963 & $18.3 \%$ & 81,255 & 2002 & $17.2 \%$ & 318,356 \\
\hline 1886 & $33.0 \%$ & 14,485 & 1925 & $17.7 \%$ & 20,253 & 1964 & $20.0 \%$ & 93,157 & 2003 & $16.1 \%$ & 299,379 \\
\hline 1887 & $34.1 \%$ & 15,180 & 1926 & $18.3 \%$ & 21,271 & 1965 & $20.4 \%$ & 100,223 & 2004 & $16.4 \%$ & 317,451 \\
\hline 1888 & $35.2 \%$ & 16,390 & 1927 & $18.5 \%$ & 22,334 & 1966 & $19.9 \%$ & 101,979 & 2005 & $18.3 \%$ & 364,625 \\
\hline 1889 & $37.7 \%$ & 18,234 & 1928 & $18.2 \%$ & 22,843 & 1967 & $19.9 \%$ & 108,287 & 2006 & $20.4 \%$ & 415,933 \\
\hline 1890 & $34.0 \%$ & 16,901 & 1929 & $18.3 \%$ & 25,152 & 1968 & $19.9 \%$ & 111,028 & 2007 & $19.9 \%$ & 416,546 \\
\hline 1891 & $32.1 \%$ & 16,119 & 1930 & $17.8 \%$ & 26,317 & 1969 & $19.6 \%$ & 114,076 & 2008 & $18.9 \%$ & 398,184 \\
\hline 1892 & $30.4 \%$ & 15,526 & 1931 & $18.5 \%$ & 25,225 & 1970 & $19.4 \%$ & 118,099 & 2009 & $16.0 \%$ & 330,997 \\
\hline 1893 & $30.7 \%$ & 16,092 & 1932 & $19.3 \%$ & 27,641 & 1971 & $10.0 \%$ & 64,087 & 2010 & $15.7 \%$ & 327,057 \\
\hline 1894 & $29.9 \%$ & 15,763 & 1933 & $18.9 \%$ & 27,704 & 1972 & $11.4 \%$ & 77,327 & 2011 & $16.6 \%$ & 348,608 \\
\hline 1895 & $33.1 \%$ & 17,681 & 1934 & $18.6 \%$ & 28,227 & 1973 & $11.9 \%$ & 84,299 & 2012 & $15.1 \%$ & 325,806 \\
\hline 1896 & $31.8 \%$ & 17,448 & 1935 & $18.4 \%$ & 29,443 & 1974 & $12.5 \%$ & 91,700 & 2013 & $13.5 \%$ & 293,925 \\
\hline 1897 & $29.4 \%$ & 17,020 & 1936 & $17.1 \%$ & 29,205 & 1975 & $11.9 \%$ & 92,089 & 2014 & $12.6 \%$ & 280,640 \\
\hline 1898 & $28.9 \%$ & 16,872 & 1937 & $18.2 \%$ & 32,429 & 1976 & $12.5 \%$ & 101,946 & 2015 & & \\
\hline 1899 & $27.2 \%$ & 16,358 & 1938 & $17.2 \%$ & 31,350 & 1977 & $12.7 \%$ & 107,816 & & & \\
\hline 1900 & $26.1 \%$ & 15,899 & 1939 & $17.2 \%$ & 32,785 & 1978 & $11.9 \%$ & 105,544 & & & \\
\hline 1901 & $27.9 \%$ & 17,433 & 1940 & $15.5 \%$ & 30,118 & 1979 & $12.1 \%$ & 111,525 & & & \\
\hline 1902 & $29.1 \%$ & 18,463 & 1941 & & & 1980 & $13.7 \%$ & 131,630 & & & \\
\hline 1903 & $30.4 \%$ & 19,142 & 1942 & & & 1981 & $14.2 \%$ & 138,736 & & & \\
\hline 1904 & $29.2 \%$ & 18,407 & 1943 & & & 1982 & $13.6 \%$ & 133,539 & & & \\
\hline 1905 & $26.6 \%$ & 16,879 & 1944 & & & 1983 & $13.5 \%$ & 138,288 & & & \\
\hline 1906 & $26.9 \%$ & 17,773 & 1945 & & & 1984 & $15.5 \%$ & 167,892 & & & \\
\hline 1907 & $24.7 \%$ & 17,029 & 1946 & & & 1985 & $17.7 \%$ & 202,795 & & & \\
\hline 1908 & $23.9 \%$ & 17,013 & 1947 & $14.5 \%$ & 32,523 & 1986 & $18.6 \%$ & 220,652 & & & \\
\hline 1909 & $23.7 \%$ & 17,277 & 1948 & $14.7 \%$ & 35,084 & 1987 & $16.5 \%$ & 198,996 & & & \\
\hline 1910 & $24.2 \%$ & 18,354 & 1949 & $14.8 \%$ & 36,509 & 1988 & $15.5 \%$ & 187,009 & & & \\
\hline
\end{tabular}


Table B2: Definition of Monetary Aggregates:

\begin{tabular}{|c|l|l|}
\hline \multicolumn{3}{|c|}{ Norway } \\
\hline Variable: & Definition: & Additional remarks: \\
\hline M0 & $\begin{array}{l}\text { Total currency in circulation (notes and } \\
\text { coins) plus total demand deposits at } \\
\text { Norges Bank, excluding Treasury } \\
\text { deposits. }\end{array}$ & $\begin{array}{l}\text { The data also includes currency in the } \\
\text { hands of the public which I will treat as } \\
\text { M0 in the UK sense of the word. }\end{array}$ \\
\hline M1 & $\begin{array}{l}\text { An M1 variable does not exist however } \\
\text { one has been created to the UK definition } \\
\text { using the Norwegian definition of M0. }\end{array}$ & \\
\hline M2 & $\begin{array}{l}\text { M2 is defined as total currency in } \\
\text { circulation minus currency held by banks } \\
\text { plus savings and commercial bank } \\
\text { deposits. }\end{array}$ \\
\hline
\end{tabular}

Table B3: Data Sources:

\begin{tabular}{|c|c|c|c|}
\hline \multirow[b]{3}{*}{ Variable } & \multicolumn{3}{|c|}{ Norway } \\
\hline & 1870-1913 & 1913-1970 & 1970-2015 \\
\hline & & & \\
\hline \multirow{3}{*}{$\begin{array}{l}\text { Monetary Aggregates } \\
\text { GDP } \\
\text { Interest Rate }\end{array}$} & \multicolumn{3}{|c|}{$\begin{array}{c}\text { Eitrheim, Ø , Klovland J.T, and Qvigstad F.S (2003) "Historical Monetary Statistics for } \\
\text { Norway 1819-2003" Norgesbank Occasional Paper No.35 }\end{array}$} \\
\hline & \multicolumn{3}{|c|}{ Norgesbank, 2016} \\
\hline & \multicolumn{3}{|c|}{ Schularick and Taylor (2012) supplemented by Norgesbank data } \\
\hline Tax Burden & \multicolumn{2}{|c|}{$\begin{array}{l}\text { Mitchell International Historical Statistics, Europe 1750- } \\
\qquad 2000 .\end{array}$} & OECD \\
\hline Self-Employment Rate & & $\begin{array}{l}\text { Measurement and Behaviour of } \\
\text { Unemployment, NBER Series } \\
\text { C2649 }\end{array}$ & OECD \\
\hline Unemployment Rate & & “ & OECD \\
\hline \multirow{2}{*}{$\begin{array}{l}\text { Total Government } \\
\text { Expenditure } \\
\text { Total Welfare } \\
\text { Expenditure }\end{array}$} & & NBER working paper 15982 & OECD \\
\hline & & & OECD \\
\hline Size of Public Sector & & $\begin{array}{l}\text { Public Spending in the 20th } \\
\text { Century: A Global Perspective } \\
\text { Lugder, V. (2000) }\end{array}$ & OECD \\
\hline Fraud Incidence & & \multicolumn{2}{|c|}{$\begin{array}{c}\text { Punishment and Crime in Scandinavia, 1750-2008 (Von } \\
\text { Hofer, 2013) supplemented with Nordic Criminal Statistics } \\
\text { 1950-2015. }\end{array}$} \\
\hline $\begin{array}{l}\text { Wages and Salaries in } \\
\text { national Income }\end{array}$ & \multicolumn{3}{|c|}{ http://www.norges-bank.no/pages/64940/Nominal_wages_in_Norway.pdf } \\
\hline
\end{tabular}


Table B4: Unit Root Test:

\begin{tabular}{|c|c|c|c|c|c|c|}
\hline \multirow{4}{*}{$\begin{array}{l}\text { Variable } \\
\mathrm{C} / \mathrm{M} 2\end{array}$} & \multicolumn{6}{|c|}{ Norway 1970-2015 } \\
\hline & \multicolumn{3}{|c|}{ At Level } & \multicolumn{3}{|c|}{ First Difference } \\
\hline & Intercept & $\begin{array}{l}\text { Trend } \\
\text { and } \\
\text { Intercept }\end{array}$ & $\begin{array}{l}\text { No Trend } \\
\text { No } \\
\text { Intercept }\end{array}$ & Intercept & $\begin{array}{l}\text { Trend and } \\
\text { Intercept }\end{array}$ & $\begin{array}{l}\text { No Trend No } \\
\text { Intercept }\end{array}$ \\
\hline & -1.26 & -0.282 & 5.122 & $-3.337 * *$ & $-3.454^{* *}$ & $-2.574 * *$ \\
\hline Y/Cap & -2.381 & -2.311 & -0.662 & $-7.783 * * *$ & $-7.738 * * *$ & $-7.867 * * *$ \\
\hline $\mathbf{R}$ & -0.225 & -1.44 & -0.701 & $-7.823 * * *$ & $-8.700 * * *$ & $-7.824 * * *$ \\
\hline Tax & -0.664 & -1.603 & -0.773 & $-4.985 * * *$ & $-4.948 * * *$ & $-5.001 * * *$ \\
\hline SELF & -1.984 & -1.458 & $-4.315^{*}$ & $-7.210 * * *$ & $-7.638 * * *$ & $-5.599 * * *$ \\
\hline REG & $-2.971^{*}$ & -0.278 & $2.738^{*}$ & $-4.824 * * *$ & $-5.959 * * *$ & $-3.934 * * *$ \\
\hline TOT EXP & -2.389 & -2.771 & 1.303 & $-6.046 * * *$ & $-6.038 * * *$ & $-5.923 * * *$ \\
\hline FRAUD & -0.819 & $-3.423^{*}$ & 0.287 & $-3.733 * * *$ & $-3.708 * *$ & $-10.006 * * *$ \\
\hline
\end{tabular}

Reported above are the T-statistics for the Augmented Dicky-Fuller (ADF) test.

Null hypothesis: variable has unit root.

The lag length was chosen using the Schwarz Information Criterion.

$*$, **, *** indicate significance at the 10,5 , and 1 percent level respectively.

Source: Own calculations 
Table B5: Stability Analysis:

\begin{tabular}{|c|c|c|c|c|c|}
\hline \multirow[b]{3}{*}{ Dependent Variable } & \multicolumn{5}{|c|}{ Cointegrating Coefficients Norway } \\
\hline & \multicolumn{2}{|c|}{ 1913-1970 } & \multicolumn{3}{|c|}{ 1970-2015 } \\
\hline & $\mathrm{C}$ & $\mathrm{C} / \mathrm{M} 2$ & $\mathrm{C}$ & $\mathrm{C} / \mathrm{M} 2$ & $\mathrm{C} / \mathrm{M} 2$ \\
\hline & OLS & OLS & 1.00 & 1.00 & 1.00 \\
\hline Y/capita (real income/capita) & $\begin{array}{c}- \\
2.14 * * * \\
(0.08)\end{array}$ & & $\begin{array}{c}2.21 * * * \\
(.58)\end{array}$ & $\begin{array}{c}\mathbf{1 . 3 8} * * \\
(.80)\end{array}$ & \\
\hline $\mathbf{Y}$ (real income) & & $\begin{array}{c}-.865 * * * \\
(.16)\end{array}$ & & & $\begin{array}{c}2.501 * * * \\
(.09)\end{array}$ \\
\hline $\mathbf{R}$ (interest rate) & $\begin{array}{c}\mathbf{- 0 . 4 6 6} \\
(.34)\end{array}$ & $\begin{array}{c}-.55 * * \\
(.37)\end{array}$ & $\begin{array}{l}.121 \\
(.11)\end{array}$ & $\begin{array}{l}.245 * \\
(.15)\end{array}$ & $\begin{array}{r}\mathbf{0 . 2 8 7} \\
(.02)\end{array}$ \\
\hline TAX2 (Alternative tax burden) & $\begin{array}{c}2.745 * * \\
(.33)\end{array}$ & $\begin{array}{c}1.059 * \\
(.59)\end{array}$ & $\begin{array}{c}1.339 * * * \\
(.12)\end{array}$ & $\begin{array}{l}\mathbf{- 5 . 2 1} * \\
(3.26)\end{array}$ & $\begin{array}{c}\mathbf{- 9 . 8 3 9} * * * \\
(2.55)\end{array}$ \\
\hline REG (public employment) & & & $\begin{array}{c}0.724 * * * \\
(.15)\end{array}$ & & \\
\hline SELF (self-employment) & & & $\begin{array}{c}-\mathbf{1 . 4 3 8} * * \\
(.69)\end{array}$ & & $\begin{array}{c}-.0641 \\
(.16)\end{array}$ \\
\hline CRIME (fraud incidence) & $\begin{array}{l}.129 * * \\
(.07)\end{array}$ & & & & \\
\hline $\begin{array}{l}\text { SOC (social welfare } \\
\text { expenditure) }\end{array}$ & & & & $\begin{array}{l}\text { 3.501* } \\
(2.03)\end{array}$ & $\begin{array}{c}\mathbf{1 . 3 8 1} * * * \\
(.41)\end{array}$ \\
\hline $\begin{array}{l}\text { GOV (government } \\
\text { expenditure) }\end{array}$ & & & $\begin{array}{l}.194 \\
(.17)\end{array}$ & & \\
\hline UE (Unemployment rate) & $\begin{array}{c}\mathbf{0 . 1 6} * * \\
(.09)\end{array}$ & $\begin{array}{l}.466 * * \\
(.08)\end{array}$ & & $\begin{array}{l}.231 * * * \\
(.05)\end{array}$ & \\
\hline Constant & $4.32 * *$ & $16 . \overline{-} * * * *$ & $12.412 * * *$ & $14.93 * * *$ & $14.17 * * *$ \\
\hline & $(1.70)$ & $(3.34)$ & $(1.17)$ & $(.83)$ & $(1.70)$ \\
\hline Log Likelohood & & & 228.95 & 183.57 & 250.96 \\
\hline Observations & 58 & 58 & 50 & 47 & 47 \\
\hline Autocorrelation LM Test & & & 35.028 & 28.1218 & 41.08 \\
\hline Lags & 1 & 1 & 1 & 4 & 4 \\
\hline D-Watson & 1.74 & 1.68 & & & \\
\hline
\end{tabular}




\section{Appendix C: Sweden}

Table C1: Shadow Economy estimates 1872-2015.

(1) Size of the shadow economy as a percentage of GDP

(2) The monetary value of the shadow economy (million NOK) in real terms (2005 prices)

\begin{tabular}{|c|c|c|c|c|c|c|c|c|c|c|c|}
\hline & (1) & (2) & & (1) & (2) & & (1) & (2) & & (1) & (2) \\
\hline Year & $\begin{array}{l}\% \text { of } \\
\text { GDP }\end{array}$ & SEK mn & Year & $\begin{array}{l}\text { \% of } \\
\text { GDP }\end{array}$ & SEK mn & Year & $\begin{array}{l}\text { \% of } \\
\text { GDP }\end{array}$ & SEK $\mathrm{mn}$ & Year & $\begin{array}{l}\text { \% of } \\
\text { GDP }\end{array}$ & SEK $\mathrm{mn}$ \\
\hline 1872 & $10.4 \%$ & 7,251 & 1911 & $20.6 \%$ & 37,797 & 1950 & $11.5 \%$ & 59,654 & 1989 & $10.7 \%$ & 180,302 \\
\hline 1873 & $7.2 \%$ & 5,238 & 1912 & $20.3 \%$ & 38,684 & 1951 & $10.0 \%$ & 54,021 & 1990 & $8.2 \%$ & 139,673 \\
\hline 1874 & $14.6 \%$ & 10,514 & 1913 & $15.2 \%$ & 30,867 & 1952 & $13.5 \%$ & 73,886 & 1991 & $8.0 \%$ & 134,557 \\
\hline 1875 & $16.3 \%$ & 12,000 & 1914 & $11.5 \%$ & 23,204 & 1953 & $17.8 \%$ & 99,714 & 1992 & $8.0 \%$ & 133,178 \\
\hline 1876 & $23.0 \%$ & 18,021 & 1915 & $8.7 \%$ & 17,994 & 1954 & $16.3 \%$ & 96,939 & 1993 & $7.8 \%$ & 127,228 \\
\hline 1877 & $20.7 \%$ & 16,104 & 1916 & $7.2 \%$ & 15,957 & 1955 & $20.6 \%$ & 126,627 & 1994 & $8.5 \%$ & 142,273 \\
\hline 1878 & $33.3 \%$ & 25,715 & 1917 & $7.7 \%$ & 14,932 & 1956 & $16.6 \%$ & 105,208 & 1995 & $8.5 \%$ & 148,395 \\
\hline 1879 & $47.5 \%$ & 39,361 & 1918 & $8.7 \%$ & 16,442 & 1957 & $15.8 \%$ & 102,705 & 1996 & $8.3 \%$ & 145,489 \\
\hline 1880 & $45.5 \%$ & 36,403 & 1919 & $17.0 \%$ & 32,769 & 1958 & $15.0 \%$ & 99,244 & 1997 & $7.9 \%$ & 141,625 \\
\hline 1881 & $40.7 \%$ & 33,344 & 1920 & $20.9 \%$ & 42,086 & 1959 & $14.8 \%$ & 103,533 & 1998 & $7.6 \%$ & 141,911 \\
\hline 1882 & $38.8 \%$ & 31,212 & 1921 & $21.6 \%$ & 39,189 & 1960 & $15.3 \%$ & 111,395 & 1999 & $7.2 \%$ & 138,252 \\
\hline 1883 & $48.0 \%$ & 41,452 & 1922 & $20.5 \%$ & 41,571 & 1961 & $16.6 \%$ & 127,886 & 2000 & $7.1 \%$ & 142,342 \\
\hline 1884 & $46.2 \%$ & 39,973 & 1923 & $19.0 \%$ & 39,811 & 1962 & $20.4 \%$ & 164,881 & 2001 & $6.8 \%$ & 143,960 \\
\hline 1885 & $32.5 \%$ & 29,011 & 1924 & $19.7 \%$ & 43,634 & 1963 & $26.8 \%$ & 228,273 & 2002 & $6.9 \%$ & 147,326 \\
\hline 1886 & $32.5 \%$ & 28,938 & 1925 & $18.0 \%$ & 39,844 & 1964 & $24.5 \%$ & 223,933 & 2003 & $6.8 \%$ & 150,200 \\
\hline 1887 & $28.2 \%$ & 24,843 & 1926 & $19.4 \%$ & 45,857 & 1965 & $22.8 \%$ & 216,783 & 2004 & $6.8 \%$ & 155,581 \\
\hline 1888 & $26.5 \%$ & 24,512 & 1927 & $17.1 \%$ & 41,888 & 1966 & $26.0 \%$ & 251,384 & 2005 & $6.7 \%$ & 166,422 \\
\hline 1889 & $26.2 \%$ & 23,880 & 1928 & $21.8 \%$ & 54,495 & 1967 & $23.0 \%$ & 229,543 & 2006 & $6.7 \%$ & 167,046 \\
\hline 1890 & $29.9 \%$ & 28,664 & 1929 & $21.8 \%$ & 58,612 & 1968 & $22.5 \%$ & 233,686 & 2007 & $6.7 \%$ & 184,225 \\
\hline 1891 & $28.5 \%$ & 26,849 & 1930 & $21.2 \%$ & 59,258 & 1969 & $31.5 \%$ & 343,757 & 2008 & $6.7 \%$ & 201,561 \\
\hline 1892 & $27.5 \%$ & 27,351 & 1931 & $21.5 \%$ & 59,555 & 1970 & $33.1 \%$ & 382,807 & 2009 & $6.8 \%$ & 211,005 \\
\hline 1893 & $28.8 \%$ & 29,903 & 1932 & $22.3 \%$ & 59,318 & 1971 & $31.3 \%$ & 361,783 & 2010 & $6.9 \%$ & 205,423 \\
\hline 1894 & $30.7 \%$ & 32,280 & 1933 & $22.7 \%$ & 62,611 & 1972 & $29.6 \%$ & 350,940 & 2011 & $7.1 \%$ & 224,396 \\
\hline 1895 & $39.1 \%$ & 42,967 & 1934 & $20.2 \%$ & 59,094 & 1973 & $28.1 \%$ & 345,898 & 2012 & $7.3 \%$ & 243,655 \\
\hline 1896 & $36.0 \%$ & 41,022 & 1935 & $18.4 \%$ & 57,338 & 1974 & $27.7 \%$ & 356,443 & 2013 & $7.5 \%$ & 262,470 \\
\hline 1897 & $21.1 \%$ & 25,308 & 1936 & $14.0 \%$ & 46,447 & 1975 & $25.7 \%$ & 336,064 & 2014 & $7.9 \%$ & 274,692 \\
\hline 1898 & $14.9 \%$ & 18,481 & 1937 & $10.2 \%$ & 34,480 & 1976 & $25.0 \%$ & 329,108 & & & \\
\hline 1899 & $16.6 \%$ & 21,768 & 1938 & $8.3 \%$ & 29,112 & 1977 & $23.9 \%$ & 310,228 & & & \\
\hline 1900 & $30.4 \%$ & 39,716 & 1939 & $10.8 \%$ & 41,658 & 1978 & $22.5 \%$ & 297,207 & & & \\
\hline 1901 & $21.5 \%$ & 28,717 & 1940 & $12.4 \%$ & 43,522 & 1979 & $20.5 \%$ & 281,526 & & & \\
\hline 1902 & $17.6 \%$ & 23,478 & 1941 & $10.2 \%$ & 35,943 & 1980 & $19.5 \%$ & 272,352 & & & \\
\hline 1903 & $25.5 \%$ & 35,810 & 1942 & $10.2 \%$ & 36,393 & 1981 & $18.7 \%$ & 261,212 & & & \\
\hline 1904 & $24.1 \%$ & 35,111 & 1943 & $13.6 \%$ & 51,223 & 1982 & $17.7 \%$ & 248,806 & & & \\
\hline 1905 & $23.2 \%$ & 33,888 & 1944 & $17.2 \%$ & 66,689 & 1983 & $16.4 \%$ & 236,534 & & & \\
\hline 1906 & $23.7 \%$ & 37,526 & 1945 & $20.4 \%$ & 80,732 & 1984 & $15.3 \%$ & 229,050 & & & \\
\hline 1907 & $23.4 \%$ & 39,575 & 1946 & $14.9 \%$ & 65,316 & 1985 & $15.1 \%$ & 231,422 & & & \\
\hline 1908 & $25.7 \%$ & 42,896 & 1947 & $15.7 \%$ & 73,688 & 1986 & $13.8 \%$ & 215,468 & & & \\
\hline 1909 & $22.8 \%$ & 38,255 & 1948 & $15.9 \%$ & 75,659 & 1987 & $13.1 \%$ & 211,696 & & & \\
\hline 1910 & $22.6 \%$ & 40,074 & 1949 & $17.7 \%$ & 86,111 & 1988 & $12.3 \%$ & 203,159 & & & \\
\hline
\end{tabular}


Table C2: Definition of Monetary Aggregates.

\begin{tabular}{|c|l|}
\hline \multicolumn{2}{|l|}{ Sweden } \\
\hline Variable: & Definition: \\
\hline M0 & Notes and coins in circulation with the non-bank public. \\
\hline M1 & $\begin{array}{l}\text { Narrow money, comprises M0 plus deposits that are immediately convertible into } \\
\text { currency or used as means of payment, i.e. demand deposits. }\end{array}$ \\
\hline $\mathbf{M 2}$ & $\begin{array}{l}\text { M1 plus deposits with a term of maturity of up to two years and deposits redeemable } \\
\text { at up to three months' notice. }\end{array}$ \\
\hline M3 & $\begin{array}{l}\text { M3 according to the new definition comprises M2 plus interest-bearing securities with } \\
\text { a term to maturity of up to two years. The old (but not the new) definition of M3 also } \\
\text { included deposits with agreed-upon terms to maturity of more than two years and } \\
\text { deposits redeemable at more than three months' notice. M3 according to the new (but } \\
\text { not the old) definition includes shares in money-market funds, money-market } \\
\text { instruments and other securities with terms to maturity of up to two years. Since this } \\
\text { variable is not used in the econometric estimation the change in its definition will have } \\
\text { little effect on the results. }\end{array}$ \\
\hline
\end{tabular}

Table C3: Data Sources:

\begin{tabular}{|c|c|c|c|}
\hline & \multicolumn{3}{|c|}{ Sweden } \\
\hline & $1870-1913$ & 1913-1970 & 1970-2015 \\
\hline \multicolumn{4}{|l|}{ Variable } \\
\hline $\begin{array}{l}\text { Monetary } \\
\text { Aggregates: }\end{array}$ & \multicolumn{3}{|c|}{$\begin{array}{c}\text { Edvinnson, R. and Ógren, A. (2013) Swedish Money Supply 1620-2012, Historical Monetary and } \\
\text { Financial Statistics for Sweden, Volume II, available at: } \\
\text { http://www.riksbank.se/Documents/Forskning/\%C3\%96vrigt/2014/Chapter7_\%20volume2_140613 } \\
\text {.pdf }\end{array}$} \\
\hline GDP & \multicolumn{3}{|c|}{ Edvinsson, R. (2016) http://www.historicalstatistics.org/ } \\
\hline Interest Rate & \multicolumn{3}{|c|}{ Schularick and Taylor (2012) supplemented by Riksbank data } \\
\hline Tax Burden & $\begin{array}{l}\text { Mitchell International } \\
\text { Historical Statistics, Europe } \\
\text { 1750- } 2000\end{array}$ & Stenkula et al(2014) & OECD \\
\hline $\begin{array}{l}\text { Self-Employment } \\
\text { Rate }\end{array}$ & & Edvinsson, R. (2016) & OECD \\
\hline $\begin{array}{l}\text { Unemployment } \\
\text { Rate }\end{array}$ & & Edvinsson, R. (2016) & OECD \\
\hline $\begin{array}{l}\text { Total Government } \\
\text { Expenditure }\end{array}$ & & Edvinsson, R. (2016) & OECD \\
\hline $\begin{array}{l}\text { Total Welfare } \\
\text { Expenditure }\end{array}$ & & Edvinsson, R. (2016) & OECD \\
\hline $\begin{array}{l}\text { Size of Public } \\
\text { Sector }\end{array}$ & & $\begin{array}{l}\text { Public Employment in Western } \\
\text { Nations }\end{array}$ & OECD \\
\hline Fraud Incidence & & \multicolumn{2}{|c|}{$\begin{array}{l}\text { Punishment and Crime in Scandinavia, 1750-2008 (Von Hofer, } \\
\text { 2013) supplemented with Nordic Criminal Statistics 1950-2015. }\end{array}$} \\
\hline $\begin{array}{l}\text { Wages and Salaries } \\
\text { in national Income }\end{array}$ & \multicolumn{3}{|c|}{ Edvinsson R (2016) available at: http://www.historicalstatistics.org/ } \\
\hline
\end{tabular}


Table C4: Unit Root Tests.

\begin{tabular}{|c|c|c|c|c|c|c|}
\hline \multirow{4}{*}{$\begin{array}{l}\text { Variable } \\
\mathrm{C} / \mathrm{M} 2\end{array}$} & \multicolumn{6}{|c|}{ Sweden 1913-1970 } \\
\hline & \multicolumn{3}{|c|}{ At Level } & \multicolumn{3}{|c|}{ First Difference } \\
\hline & Intercept & $\begin{array}{l}\text { Trend } \\
\text { and } \\
\text { Intercept }\end{array}$ & $\begin{array}{l}\text { No Trend } \\
\text { No } \\
\text { Intercept }\end{array}$ & Intercept & $\begin{array}{l}\text { Trend and } \\
\text { Intercept }\end{array}$ & $\begin{array}{l}\text { No Trend No } \\
\text { Intercept }\end{array}$ \\
\hline & -1.156 & -0.618 & -0.684 & $-6.616 * * *$ & $-6.669 * * *$ & $-6.644 * * *$ \\
\hline Y/Cap & 1.069 & -1.816 & 4.761 & $-8.106 * * *$ & $-8.406 * * *$ & $-6.166 * * *$ \\
\hline $\mathbf{R}$ & -0.630 & -0.580 & 0.786 & $-7.403 * * *$ & $-7.487^{* * *}$ & $-7.372 * * *$ \\
\hline Tax & 1.369 & -1.866 & 4.127 & $-7.402 * * *$ & $-7.801 * * *$ & $-6.050 * * *$ \\
\hline SELF & 5.421 & 2.959 & -3.424 & $-2.928 * *$ & $-4.023^{* *}$ & $-2.296 * * *$ \\
\hline REG & .638 & -2.662 & 2.882 & $-8.466 * * *$ & $-8.626 * * *$ & $-7.498 * * *$ \\
\hline WAGES & -1.294 & -2.582 & 1.434 & $-5.796 * * *$ & $-5.744 * * *$ & $-5.721 * * *$ \\
\hline
\end{tabular}

\begin{tabular}{|l|ccc|ccc|}
\hline \multirow{2}{*}{ Variable } & \multicolumn{6}{|c|}{ Sweden 1970-2015 } \\
\cline { 2 - 7 } & \multicolumn{3}{|c|}{ At Level } & \multicolumn{3}{c|}{ First Difference } \\
\cline { 2 - 7 } & Intercept & $\begin{array}{l}\text { Trend } \\
\text { and } \\
\text { Intercept }\end{array}$ & $\begin{array}{l}\text { No Trend } \\
\text { No }\end{array}$ & Intercept \\
In2 & -2.561 & -2.273 & -0.731 & $-7.337^{* * *}$ & $-7.467^{* * *}$ & $-7.338^{* * *}$ \\
Y & 0.863 & -0.709 & 1.121 & $-5.630^{* * *}$ & $-5.661^{* * *}$ & $-3.476^{* * *}$ \\
R & 0.788 & -1.005 & 1.295 & 1.486 & -.905 & $2.240^{* *}$ \\
Tax & -0.682 & -1.584 & -0.77 & $-5.038^{* * *}$ & $-4.998^{* * *}$ & $-4.214^{* * *}$ \\
SELF & -2.45 & -2.612 & -0.792 & $-7.108^{* * *}$ & $-7387^{* * *}$ & $-7.149^{* * *}$ \\
REG & $-2.627^{*}$ & -1.759 & 0.23 & $-5.704^{* * *}$ & $-6.074^{* * *}$ & $-5.677^{* * *}$ \\
TOT EXP & -0.595 & -2.098 & -1.002 & $-5.130^{* * *}$ & $-5.235^{* * *}$ & $-5.047^{* * *}$ \\
FRAUD & -1.474 & -1.261 & -0.041 & $-7.326^{* * *}$ & $-7.408^{* * *}$ & $-7.403^{* * *}$ \\
\hline
\end{tabular}

Reported above are the T-statistics for the Augmented Dicky-Fuller (ADF) test.

Null hypothesis: variable has unit root.

The lag length was chosen using the Schwarz Information Criterion.

$*, * *, * * *$ indicate significance at the 10,5 , and 1 percent level respectively.

Source: Own calculations 
Table C5: Stability Analysis:

Cointegrating Coefficients Sweden

\begin{tabular}{|c|c|c|c|c|c|c|}
\hline \multirow[b]{2}{*}{ Dependent Variable } & \multicolumn{3}{|c|}{ 1913-1970 } & \multicolumn{3}{|c|}{ 1970-2015 } \\
\hline & $\mathbf{C}$ & C/M2 & C/M2 & $\mathbf{C}$ & C/M2 & C/M2 \\
\hline & 1.00 & 1.00 & 1.00 & 1.00 & 1.00 & 1.00 \\
\hline Y/capita (real income/capita) & $\begin{array}{c}1.96 * * * \\
.24\end{array}$ & $\begin{array}{c}\mathbf{- 1 . 2 5 1} * * * \\
(.34)\end{array}$ & & $\begin{array}{c}1.16 * * \\
(.65)\end{array}$ & $\begin{array}{c}.851 * * \\
(.48)\end{array}$ & \\
\hline $\mathbf{Y}$ (real income) & & & $\begin{array}{c}-.441 * * * \\
(.15)\end{array}$ & & & $\begin{array}{c}1.204 * * * \\
(.22)\end{array}$ \\
\hline $\mathbf{R}$ (interest rate) & $\begin{array}{c}-.208 * * * \\
(.07)\end{array}$ & $\begin{array}{c}. \mathbf{2 3 3} * * * * \\
(.09)\end{array}$ & $\begin{array}{c}\mathbf{0 . 1 1} * * * \\
(.001)\end{array}$ & $\begin{array}{c}. \mathbf{4 1 1} * * * \\
(.11)\end{array}$ & $\begin{array}{c}.325 * * * \\
(.06)\end{array}$ & $\begin{array}{c}. \mathbf{4 1 3} * * * \\
(.02)\end{array}$ \\
\hline $\begin{array}{l}\text { TAX } 2 \text { (Top Marginal tax } \\
\text { Rate) }\end{array}$ & $\begin{array}{c}.471 * * * \\
(.12)\end{array}$ & $\begin{array}{c}2.389 * * \\
(.07)\end{array}$ & $\begin{array}{c}1.147 * * * \\
(.15)\end{array}$ & $\begin{array}{c}1.18 * * * \\
(.12)\end{array}$ & $\begin{array}{c}3.145 * * \\
(1.67)\end{array}$ & $\begin{array}{c}2.223 * * * \\
(.15)\end{array}$ \\
\hline REG (public employment) & & & $\begin{array}{l}.54 * * * \\
(.02)\end{array}$ & $\begin{array}{c}.454 * * * \\
(.17)\end{array}$ & $\begin{array}{c}.743 * * * \\
(.24)\end{array}$ & \\
\hline SELF (self-employment) & $\begin{array}{c}1.254 * \\
(.76)\end{array}$ & & $\begin{array}{c}1.421 * * \\
(.63)\end{array}$ & $\begin{array}{c}\mathbf{1 . 7 8 7} * * * \\
(.08)\end{array}$ & & $\begin{array}{l}.883 * * \\
(.489)\end{array}$ \\
\hline $\begin{array}{l}\text { CRIME (fraud incidence) } \\
\text { SOC (social welfare } \\
\text { expenditure) }\end{array}$ & $.45 * * *$ & $\begin{array}{c}. \mathbf{4 2} * * \\
(.19)\end{array}$ & & $\begin{array}{c}.358 * * * \\
(.11)\end{array}$ & $3.493^{*}$ & $\begin{array}{c}.130 * * \\
(.07) \\
- \\
1.471 * * *\end{array}$ \\
\hline $\begin{array}{l}\text { GOV (government } \\
\text { expenditure) }\end{array}$ & $(.03)$ & $\begin{array}{c}\mathbf{- 1 . 7 5 1} * * * \\
(.41)\end{array}$ & & $\begin{array}{l}.176 \\
(.18)\end{array}$ & $(2.03)$ & $(.41)$ \\
\hline $\begin{array}{l}\text { WAGE (Wages \& Salaries in } \\
\text { Nat Income) }\end{array}$ & & $\begin{array}{c}\mathbf{- 4 . 1 4 4} * * * \\
(1.21)\end{array}$ & $\begin{array}{c}-.655 * * * \\
(.008)\end{array}$ & & & \\
\hline UE (Unemployment rate) & & & & & $\begin{array}{c}.724 * * * \\
(0.18)\end{array}$ & \\
\hline Constant & $\begin{array}{c}\text { 3.648 } * * * \\
(.741) \\
\end{array}$ & $\begin{array}{c}-\overline{-} \\
\mathbf{1 0 . 1 2 6} * * * \\
(2.01) \\
\end{array}$ & $\begin{array}{c}\text { 14.251**** } \\
(3.41) \\
\end{array}$ & $\begin{array}{c}- \\
\mathbf{7 . 4 2 1} * * * \\
(1.79)\end{array}$ & $\begin{array}{c}18.26 * * * \\
(3.51) \\
\end{array}$ & $\begin{array}{r}\mathbf{1 2 . 5 1} \\
(11.13) \\
\end{array}$ \\
\hline Observations & 58 & 55 & 55 & 50 & 47 & 47 \\
\hline Autocorrelation LM Test & 22.28 & 33.71 & 24.01 & 34.95 & 54.15 & 48.94 \\
\hline Lag & 1 & 4 & 4 & 1 & 4 & 4 \\
\hline LogLiklihood & 181.56 & 220.51 & 181.04 & 225.03 & 391.06 & 321.614 \\
\hline
\end{tabular}




\section{Appendix D: United States}

Table D1: Shadow Economy Estimates.

1) Size of the shadow economy as a percentage of GDP

(2) The monetary value of the shadow economy (million USD) in real terms (2009 prices)

\begin{tabular}{|c|c|c|c|c|c|c|c|c|c|c|c|}
\hline & (1) & (2) & & (1) & (2) & & (1) & (2) & & (1) & (2) \\
\hline Year & $\%$ of GDP & USD mn & Year & $\%$ of GDP & USD mn & Year & $\%$ of GDP & USD mn & Year & $\%$ of GDP & USD mn \\
\hline 1870 & $10.2 \%$ & 12,330 & 1908 & $17.9 \%$ & 95,078 & 1946 & $15.9 \%$ & 312,707 & 1984 & $13.1 \%$ & 954,240 \\
\hline 1871 & $10.5 \%$ & 13,295 & 1909 & $22.9 \%$ & 130,689 & 1947 & $13.5 \%$ & 261,176 & 1985 & $13.5 \%$ & $1,026,496$ \\
\hline 1872 & $9.7 \%$ & 13,409 & 1910 & $23.1 \%$ & 133,194 & 1948 & $13.2 \%$ & 267,399 & 1986 & $13.0 \%$ & $1,025,610$ \\
\hline 1873 & $7.6 \%$ & 11,391 & 1911 & $26.7 \%$ & 158,981 & 1949 & $8.6 \%$ & 173,714 & 1987 & $14.2 \%$ & $1,154,171$ \\
\hline 1874 & $7.5 \%$ & 11,451 & 1912 & $26.7 \%$ & 166,190 & 1950 & $9.1 \%$ & 198,242 & 1988 & $13.4 \%$ & $1,132,648$ \\
\hline 1875 & $10.5 \%$ & 15,915 & 1913 & $32.5 \%$ & 210,724 & 1951 & $9.4 \%$ & 222,410 & 1989 & $13.3 \%$ & $1,170,422$ \\
\hline 1876 & $10.3 \%$ & 16,320 & 1914 & $36.9 \%$ & 220,860 & 1952 & $7.5 \%$ & 183,890 & 1990 & $13.4 \%$ & $1,198,197$ \\
\hline 1877 & $11.7 \%$ & 19,410 & 1915 & $36.3 \%$ & 223,271 & 1953 & $8.4 \%$ & 216,292 & 1991 & $12.6 \%$ & $1,125,703$ \\
\hline 1878 & $12.4 \%$ & 21,246 & 1916 & $34.8 \%$ & 243,365 & 1954 & $8.4 \%$ & 214,729 & 1992 & $12.0 \%$ & $1,114,237$ \\
\hline 1879 & $10.8 \%$ & 20,651 & 1917 & $35.7 \%$ & 243,805 & 1955 & $9.7 \%$ & 266,835 & 1993 & $11.8 \%$ & $1,123,189$ \\
\hline 1880 & $11.0 \%$ & 22,694 & 1918 & $34.3 \%$ & 255,119 & 1956 & $9.5 \%$ & 267,037 & 1994 & $11.7 \%$ & $1,161,591$ \\
\hline 1881 & $9.8 \%$ & 22,943 & 1919 & $29.2 \%$ & 219,035 & 1957 & $11.0 \%$ & 313,591 & 1995 & $11.7 \%$ & $1,187,270$ \\
\hline 1882 & $10.2 \%$ & 25,135 & 1920 & $24.7 \%$ & 183,643 & 1958 & $12.7 \%$ & 360,961 & 1996 & $12.1 \%$ & $1,278,294$ \\
\hline 1883 & $10.1 \%$ & 25,403 & 1921 & $29.0 \%$ & 210,399 & 1959 & $14.5 \%$ & 440,154 & 1997 & $12.3 \%$ & $1,359,833$ \\
\hline 1884 & $10.2 \%$ & 25,246 & 1922 & $28.1 \%$ & 214,971 & 1960 & $13.2 \%$ & 409,854 & 1998 & $12.5 \%$ & $1,437,915$ \\
\hline 1885 & $6.6 \%$ & 16,459 & 1923 & $21.0 \%$ & 181,780 & 1961 & $14.1 \%$ & 449,749 & 1999 & $12.1 \%$ & $1,457,332$ \\
\hline 1886 & $8.3 \%$ & 22,410 & 1924 & $21.7 \%$ & 193,620 & 1962 & $16.2 \%$ & 546,396 & 2000 & $12.2 \%$ & $1,529,754$ \\
\hline 1887 & $9.5 \%$ & 27,541 & 1925 & $16.1 \%$ & 147,591 & 1963 & $19.3 \%$ & 679,864 & 2001 & $10.6 \%$ & $1,339,807$ \\
\hline 1888 & $9.2 \%$ & 28,206 & 1926 & $15.9 \%$ & 154,821 & 1964 & $20.1 \%$ & 750,129 & 2002 & $7.9 \%$ & $1,020,832$ \\
\hline 1889 & $9.1 \%$ & 28,581 & 1927 & $16.0 \%$ & 157,527 & 1965 & $17.2 \%$ & 685,031 & 2003 & $7.0 \%$ & 934,609 \\
\hline 1890 & $10.1 \%$ & 34,702 & 1928 & $16.6 \%$ & 165,045 & 1966 & $14.7 \%$ & 624,890 & 2004 & $7.1 \%$ & 977,363 \\
\hline 1891 & $10.3 \%$ & 36,050 & 1929 & $16.3 \%$ & 171,863 & 1967 & $18.6 \%$ & 808,942 & 2005 & $8.1 \%$ & $1,146,057$ \\
\hline 1892 & $11.8 \%$ & 43,076 & 1930 & $17.7 \%$ & 170,998 & 1968 & $17.8 \%$ & 814,011 & 2006 & $8.6 \%$ & $1,259,958$ \\
\hline 1893 & $12.7 \%$ & 43,748 & 1931 & $15.0 \%$ & 135,294 & 1969 & $19.2 \%$ & 902,743 & 2007 & $8.6 \%$ & $1,283,466$ \\
\hline 1894 & $14.5 \%$ & 47,596 & 1932 & $19.1 \%$ & 150,619 & 1970 & $22.1 \%$ & $1,042,811$ & 2008 & $7.1 \%$ & $1,048,755$ \\
\hline 1895 & $15.4 \%$ & 56,404 & 1933 & $18.1 \%$ & 141,147 & 1971 & $20.5 \%$ & 999,828 & 2009 & $5.4 \%$ & 776,004 \\
\hline 1896 & $16.8 \%$ & 60,565 & 1934 & $21.0 \%$ & 180,919 & 1972 & $21.2 \%$ & $1,089,327$ & 2010 & $5.4 \%$ & 795,496 \\
\hline 1897 & $16.7 \%$ & 62,664 & 1935 & $19.8 \%$ & 186,391 & 1973 & $20.5 \%$ & $1,111,278$ & 2011 & $5.5 \%$ & 822,806 \\
\hline 1898 & $13.7 \%$ & 57,131 & 1936 & $20.8 \%$ & 220,319 & 1974 & $21.4 \%$ & $1,156,581$ & 2012 & $5.6 \%$ & 853,938 \\
\hline 1899 & $14.1 \%$ & 63,024 & 1937 & $18.8 \%$ & 208,996 & 1975 & $19.4 \%$ & $1,042,553$ & 2013 & $6.3 \%$ & 974,376 \\
\hline 1900 & $10.2 \%$ & 46,583 & 1938 & $19.0 \%$ & 204,324 & 1976 & $17.3 \%$ & 984,338 & 2014 & $6.5 \%$ & $1,031,611$ \\
\hline 1901 & $11.1 \%$ & 53,468 & 1939 & $16.6 \%$ & 193,660 & 1977 & $19.3 \%$ & $1,143,360$ & & & \\
\hline 1902 & $12.0 \%$ & 60,552 & 1940 & $22.7 \%$ & 287,501 & 1978 & $18.0 \%$ & $1,126,040$ & & & \\
\hline 1903 & $11.7 \%$ & 61,037 & 1941 & $25.8 \%$ & 384,027 & 1979 & $17.7 \%$ & $1,142,584$ & & & \\
\hline 1904 & $12.6 \%$ & 63,032 & 1942 & $24.3 \%$ & 430,859 & 1980 & $17.7 \%$ & $1,141,685$ & & & \\
\hline 1905 & $12.2 \%$ & 68,245 & 1943 & $27.4 \%$ & 567,353 & 1981 & $18.0 \%$ & $1,188,449$ & & & \\
\hline 1906 & $16.0 \%$ & 93,099 & 1944 & $21.4 \%$ & 480,070 & 1982 & $17.6 \%$ & $1,143,976$ & & & \\
\hline 1907 & $15.4 \%$ & 92,012 & 1945 & $15.8 \%$ & 350,050 & 1983 & $13.4 \%$ & 910,305 & & & \\
\hline
\end{tabular}


Table D2: Definition of Monetary Aggregates.

\begin{tabular}{|c|l|l|}
\hline \multicolumn{3}{|c|}{ United States } \\
\hline Variable & Definition: & Additional remarks: \\
\hline M0 & $\begin{array}{l}\text { Currency in circulation refers to the currency stock } \\
\text { minus currency held by the monetary authorities. } \\
\text { The currency stock refers to the total amount of } \\
\text { currency issued in the United States in U.S. dollars, } \\
\text { including currency issued by U.S. firms and by the } \\
\text { monetary authorities (the Treasury and, after 1914, } \\
\text { the Federal Reserve) }\end{array}$ & $\begin{array}{l}\text { This definition of M0 is similar } \\
\text { to M1 in the UK (i.e. including } \\
\text { deposit accounts). However, the } \\
\text { data source allows for the } \\
\text { distinction between actual cash in } \\
\text { circulation and cash + the amount } \\
\text { in deposit accounts. }\end{array}$ \\
\hline M1 & $\begin{array}{l}\text { Currency in circulation outside the vaults of } \\
\text { depository financial institutions; traveller's checks } \\
\text { issued by nonbank financial institutions; and } \\
\text { certain deposits, transferable by cheque, that are } \\
\text { held by the nonbank public. }\end{array}$ & \\
\hline M2 & $\begin{array}{l}\text { M1 plus the nonbank public's holdings of certain } \\
\text { savings and time deposits at depository institutions } \\
\text { and of shares in retail-oriented money market } \\
\text { mutual funds. These deposits, although not } \\
\text { commonly used as medium of exchange, are highly } \\
\text { liquid. }\end{array}$ & \\
\hline M3 & $\begin{array}{l}\text { M2 plus the nonbank public's holdings of large- } \\
\text { denomination time deposits at depository financial } \\
\text { institutions and of institutionally oriented money } \\
\text { market mutual funds. }\end{array}$ & \\
\hline
\end{tabular}


Table D3: Data Sources.

\begin{tabular}{|c|c|c|c|}
\hline & \multicolumn{3}{|r|}{ United States } \\
\hline & $1870-1913$ & 1913-1970 & 1970-2015 \\
\hline \multicolumn{4}{|l|}{ Variable: } \\
\hline $\begin{array}{l}\text { Monetary } \\
\text { aggregates }\end{array}$ & \multicolumn{3}{|c|}{$\begin{array}{c}\text { Anderson, R (2003) "Historical U.S. Currency and } \\
\text { Monetary Aggregates Data" Federal Reserve Bank of St. Louis, WP 2003-006 supplemented with FRED } \\
\text { data }\end{array}$} \\
\hline GDP & \multicolumn{3}{|c|}{$\begin{array}{c}\text { Williamson, S.H (2016) "What Was the U.S. GDP Then?" MeasuringWorth, } \\
\text { URL: http://www.measuringworth.com/ukgdp/ }\end{array}$} \\
\hline Interest Rate & \multicolumn{3}{|c|}{ Schularick and Taylor 2012 supplemented by FRED data } \\
\hline \multirow{3}{*}{$\begin{array}{l}\text { Self- } \\
\text { Employment } \\
\text { Rate } \\
\text { Unemploymen } \\
\text { t Rate }\end{array}$} & $\begin{array}{c}\text { Mitchell } \\
\text { International } \\
\text { Historical Statistics, } \\
\text { The Americas } \\
\text { 1750- } 2000\end{array}$ & $\begin{array}{l}\text { Piketty, Thomas, } \\
\text { "Capital in the } 21 \text { st } \\
\text { Century, Harvard } \\
\text { University Press", } \\
2014\end{array}$ & $\begin{array}{l}\text { OECD available at } \\
\text { https://data.oecd.org/tax/tax-revenue.htm\#indicator-chart }\end{array}$ \\
\hline & & & $\begin{array}{c}\text { OECD available at } \\
\text { (http://www.oecd.org/employment/emp/employmentdataba } \\
\text { se-employment.htm) }\end{array}$ \\
\hline & & NBER C2644 & $\begin{array}{c}\text { OECD available at } \\
\text { http://www.oecd.org/employment/emp/employmentdatabas } \\
\text { e-unemployment.htm }\end{array}$ \\
\hline $\begin{array}{l}\text { Total } \\
\text { Government } \\
\text { Expenditure }\end{array}$ & \multicolumn{3}{|c|}{ http://www.usgovernmentspending.com } \\
\hline $\begin{array}{l}\text { Total Welfare } \\
\text { Expenditure }\end{array}$ & \multicolumn{3}{|c|}{ http://www.usgovernmentspending.com } \\
\hline $\begin{array}{l}\text { Size of Public } \\
\text { Sector }\end{array}$ & & $\begin{array}{l}\text { Statistical Abstract } \\
\text { of the United States } \\
1878-2012\end{array}$ & OECD \\
\hline $\begin{array}{l}\text { Fraud } \\
\text { Incidence }\end{array}$ & \multicolumn{3}{|c|}{$\begin{array}{c}\text { Historical Corrections Statistics in the United States, 1850- 1984 Dept. of Justice } \\
\text { available at: http://www.bjs.gov/content/pub/pdf/hcsus5084.pdf } \\
\text { supplemented with United States Crime Rates } 1960-2015 \\
\text { :http://www.disastercenter.com/crime/uscrime.htm }\end{array}$} \\
\hline $\begin{array}{l}\text { Wages and } \\
\text { Salaries in } \\
\text { national } \\
\text { Income }\end{array}$ & \multicolumn{3}{|c|}{ NBER C1567 supplemented with https://fred.stlouisfed.org/series/A4002E1A156NBEA } \\
\hline
\end{tabular}


Table D4: Unit Root Tests.

\begin{tabular}{|c|c|c|c|c|c|c|}
\hline \multirow{4}{*}{$\begin{array}{l}\text { Variable } \\
\text { C/M2 }\end{array}$} & \multicolumn{6}{|c|}{ United States 1913-1970 } \\
\hline & \multicolumn{3}{|c|}{ At Level } & \multicolumn{3}{|c|}{ First Difference } \\
\hline & Intercept & $\begin{array}{l}\text { Trend } \\
\text { and } \\
\text { Intercep } \\
\text { t } \\
\end{array}$ & $\begin{array}{l}\text { No Trend } \\
\text { No } \\
\text { Intercept }\end{array}$ & Intercept & $\begin{array}{l}\text { Trend and } \\
\text { Intercept }\end{array}$ & $\begin{array}{l}\text { No Trend No } \\
\text { Intercept }\end{array}$ \\
\hline & -1.030 & -1.148 & 0.659 & $-4.495 * * *$ & $-4.474 * * *$ & $-4.513 * * *$ \\
\hline Y/Cap & 0.089 & -1.988 & 2.696 & $-5.008 * * *$ & $-4.973 * * *$ & $-4.650 * * *$ \\
\hline $\mathbf{R}$ & -0.655 & -0.590 & -0.656 & $-8.316 * * *$ & $-8.665 * * *$ & $-8.331 * * *$ \\
\hline $\begin{array}{l}\text { Tax } \\
\text { WELFAR }\end{array}$ & -2.301 & -1.926 & 0.005 & $-6.352 * * *$ & $-6.479 * * *$ & $-6.318 * * *$ \\
\hline $\mathbf{E}$ & -1.100 & -1.183 & $-1.649 *$ & $-5.152 * * *$ & $-5.130 * * *$ & $-4.979 * * *$ \\
\hline WAGES & -1.773 & -3.078 & 1.538 & $-4.833 * * *$ & $-4.750 * * *$ & $-4.754 * * *$ \\
\hline FRAUD & -1.454 & 2.719 & 0.794 & $-3.504 * *$ & $-3.157 * *$ & $-3.592 * *$ \\
\hline
\end{tabular}

\begin{tabular}{|c|c|c|c|c|c|c|}
\hline \multirow{4}{*}{$\begin{array}{l}\text { Variable } \\
\text { C/M2 }\end{array}$} & \multicolumn{6}{|c|}{ United States 1970-2015 } \\
\hline & \multicolumn{3}{|c|}{ At Level } & \multicolumn{3}{|c|}{$\begin{array}{l}\text { First Difference } \\
\end{array}$} \\
\hline & Intercept & $\begin{array}{l}\text { Trend } \\
\text { and } \\
\text { Intercept }\end{array}$ & $\begin{array}{l}\text { No Trend } \\
\text { No } \\
\text { Intercept }\end{array}$ & Intercept & $\begin{array}{l}\text { Trend and } \\
\text { Intercept }\end{array}$ & $\begin{array}{l}\text { No Trend No } \\
\text { Intercept }\end{array}$ \\
\hline & 0.297 & -1.801 & -1.674 & $-4.223 * * *$ & $-4.320 * * *$ & $-4.084 * * *$ \\
\hline Y/Cap & -1.865 & -1.398 & 6.269 & $-5.570 * * *$ & $-5.628 * * *$ & $-3.877 * * *$ \\
\hline $\mathbf{R}$ & -0.712 & -2.431 & -0.665 & $-8.658 * * *$ & $-9.216^{* * *}$ & $-8.689 * * *$ \\
\hline Tax & $-2.951 *$ & -2.918 & 0.276 & $-6.000 * * *$ & $-5.937 * * *$ & $-6.050 * * *$ \\
\hline WELFARE & -2.358 & -2.114 & -0.116 & $-4.877 * * *$ & $-4.979 * * *$ & $-4.898 * * *$ \\
\hline SELF & $-2.746^{*}$ & -1.760 & -1.137 & $-5.140 * * *$ & $-5.097 * * *$ & $-4.433 * * *$ \\
\hline REG & $-2.740 *$ & -1.831 & 0.432 & $-4.416 * * *$ & $-4.345^{* * *}$ & $-4.489 * * *$ \\
\hline FRAUD & -1.427 & -0.924 & -0.254 & $-4.115 * * *$ & $-4.157 * * *$ & $-4.157 * * *$ \\
\hline
\end{tabular}

Reported above are the T-statistics for the Augmented Dicky-Fuller (ADF) test. Null hypothesis: variable has unit root.

The lag length was chosen using the Schwarz Information Criterion.

$*, * *, * * *$ indicate significance at the 10,5 , and 1 percent level respectively.

Source: Own calculations 
Table D5: Stability Analysis:

\begin{tabular}{|c|c|c|c|c|c|c|}
\hline \multirow[b]{3}{*}{ Dependent Variable } & \multicolumn{6}{|c|}{ Cointegrating Coefficients United States } \\
\hline & \multicolumn{3}{|c|}{ 1913-1970 } & \multicolumn{3}{|c|}{$1970-2015$} \\
\hline & $\mathbf{C}$ & C/M2 & C/M2 & $\mathbf{C}$ & C/M2 & C/M2 \\
\hline & 1.00 & 1.00 & 1.00 & 1.00 & 1.00 & 1.00 \\
\hline Y/capita (real income/capita) & $\begin{array}{l}2.16 * * \\
(1.15)\end{array}$ & $\begin{array}{c}\mathbf{- 0 . 8 5} * * \\
(.44)\end{array}$ & & $\begin{array}{c}1.14 * * \\
(.58)\end{array}$ & $\begin{array}{c}1.41 * * \\
(.72)\end{array}$ & \\
\hline $\mathbf{Y}$ (real income) & & & $\begin{array}{c}\mathbf{- 1 . 4 4 1 * * * *} \\
\quad(.25)\end{array}$ & & & $\begin{array}{c}2.499 * * * \\
(.09)\end{array}$ \\
\hline $\mathbf{R}$ (interest rate) & $\begin{array}{c}- \\
.191 * * * \\
(.07)\end{array}$ & $\begin{array}{c}. \mathbf{4 4 3} * * * \\
(.12)\end{array}$ & $\begin{array}{c}\mathbf{0 . 1 9 1} * * * \\
(.09)\end{array}$ & $\begin{array}{c}.321 * * * \\
(.07)\end{array}$ & $\begin{array}{c}.215 * * * \\
(.04)\end{array}$ & $\begin{array}{c}\mathbf{0 . 3 8 7} * * * \\
(.02)\end{array}$ \\
\hline TAX 2 (Top Marginal tax Rate) & $\begin{array}{c}.521 * * * \\
(.12)\end{array}$ & $\begin{array}{c}1.589 * * \\
(.07)\end{array}$ & $\begin{array}{c}2.147 * * * \\
(.15)\end{array}$ & $\begin{array}{c}1.15^{* * * *} \\
(.12)\end{array}$ & $\begin{array}{c}\mathbf{- 5 . 6 8 5 * *} \\
(3.21)\end{array}$ & $\begin{array}{c}-14.12 * * * \\
(2.15)\end{array}$ \\
\hline REG (public employment) & $\begin{array}{c}.047 * * \\
(.02\end{array}$ & & & $\begin{array}{c}.724 * * \\
(.17)\end{array}$ & $.523 * * *$ & \\
\hline SELF (self-employment) & $\begin{array}{l}.883 * \\
(.461)\end{array}$ & & $\begin{array}{c}1.421 * * \\
(.63)\end{array}$ & $\begin{array}{c}1.339 * * * \\
(.11)\end{array}$ & & $\begin{array}{r}.981 * * \\
(.489)\end{array}$ \\
\hline CRIME (fraud incidence) & & $\begin{array}{c}. \mathbf{4 1 1} * * * \\
(.13)\end{array}$ & & $.58 * *$ & & $\begin{array}{l}.511 * * \\
(.249)\end{array}$ \\
\hline SOC (social welfare expenditure) & $.45^{* * * *}$ & & & & & $-1.471 * * *$ \\
\hline GOV (government expenditure) & $(.03)$ & $2.251 * * *$ & & $.65 * * *$ & & $(.41)$ \\
\hline $\begin{array}{l}\text { WAGE (Wages \& Salaries in Nat } \\
\text { Income) }\end{array}$ & & $\begin{array}{c}(.41) \\
- \\
1.744 * * * \\
(.54)\end{array}$ & $\begin{array}{c}-\mathbf{3 . 1 2 5} * * * \\
(1.02)\end{array}$ & $(.03)$ & & \\
\hline UE (Unemployment rate) & & & & & $\begin{array}{l}1.24 * \\
(0.66)\end{array}$ & \\
\hline Constant & $\begin{array}{c}3.52 * * * \\
(1.09) \\
\end{array}$ & $\begin{array}{c}9.056 * * * \\
(2.01) \\
\end{array}$ & $\begin{array}{c}\mathbf{1 7 . 2 5 1} * * * \\
(3.41) \\
\end{array}$ & $\begin{array}{c}4.12 * * * \\
(.89) \\
\end{array}$ & $\begin{array}{c}11.26 * * * \\
(2.01)\end{array}$ & $\begin{array}{c}\mathbf{2 2 . 5 1} * * * \\
(4.12)\end{array}$ \\
\hline Observations & 59 & 56 & 56 & 50 & 47 & 47 \\
\hline Autocorrelation LM Test & 21.28 & 31.25 & 42.12 & 23.99 & 30.61 & 34.94 \\
\hline Log Likelihood & 134.064 & 229.06 & 315.9 & 149.45 & 214.27 & 237.59 \\
\hline Lags & 1 & 4 & 4 & 1 & 4 & 4 \\
\hline
\end{tabular}




\section{Appendix E: Presentation of the results over 1870 to 2015.}

We show the size and development of the shadow economy of these four countries by comparing the development of the shadow economy over time, with the interest rate, the unemployment rate, and the tax burden.

Figure E1 graphs shadow economy estimates as a percentage of GDP and the interest rate. The natural logs of both variables have been taken. In the UK the relationship appears to be positively correlated; An increase in the interest rate leads to an increase in the size of the shadow economy. The same is true in Norway and Sweden and also in the United States after 1950. Prior to 1950 in the United States the variables appear to be negatively correlated; a decrease in the interest rate leading to an increase in shadow economic activity. However, causality is difficult to prove and there may even be reverse causality; monetary policymakers, aware of the growing shadow economy, increase interest rates in an attempt to induce capital flows into the banking system again.

\section{Figure E1: Shadow Economies and the Interest Rate 1870-2015}
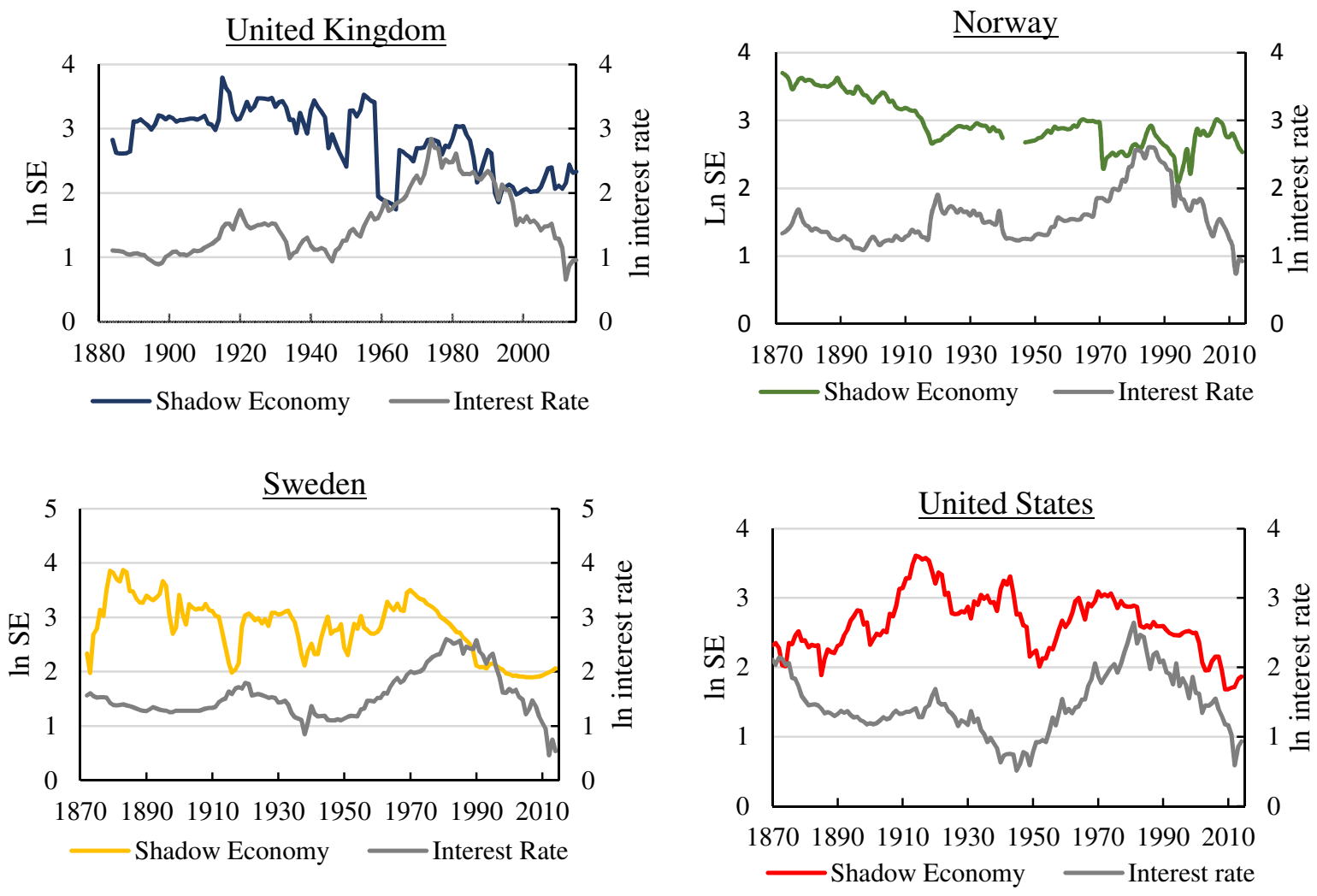

Source: Own Calculations 
The main variable of interest in this study is the tax burden and its interaction with the shadow economy. Figure E2 graphs the relationship between the natural log of these two variables from 18701970. The results show a positive correlation of the most part (with the exception of pre-1920s Norway). In the case of the UK the tax burden experiences a sharp increase in 1914, this is followed by a sharp increase in shadow economic activity in the years that follow. In the United States, during period where there was an increase or a decrease in the tax burden, shadow economic activity responded likewise. The same caveats regarding causation and reverse causality apply in this case; is the decreasing tax burden responsible for an decreasing shadow economy or are monetary policymakers reducing the tax rate in an attempt to reduce the size of the shadow economy. In the case of the UK and Sweden the graphs would imply causation since the increase (decrease) in the tax burden occurred before the increase (decrease) in the size of the shadow economy.

\section{Figure E2: Shadow Economies and the Tax Burden 1870-1970}
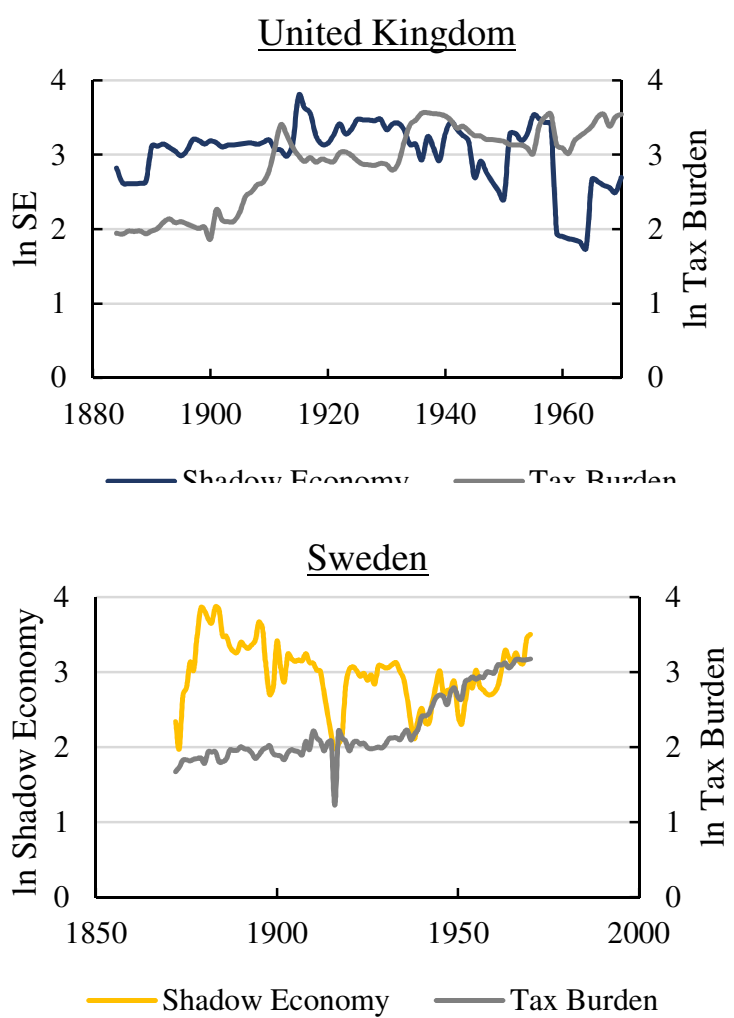

Source: Own Calculations
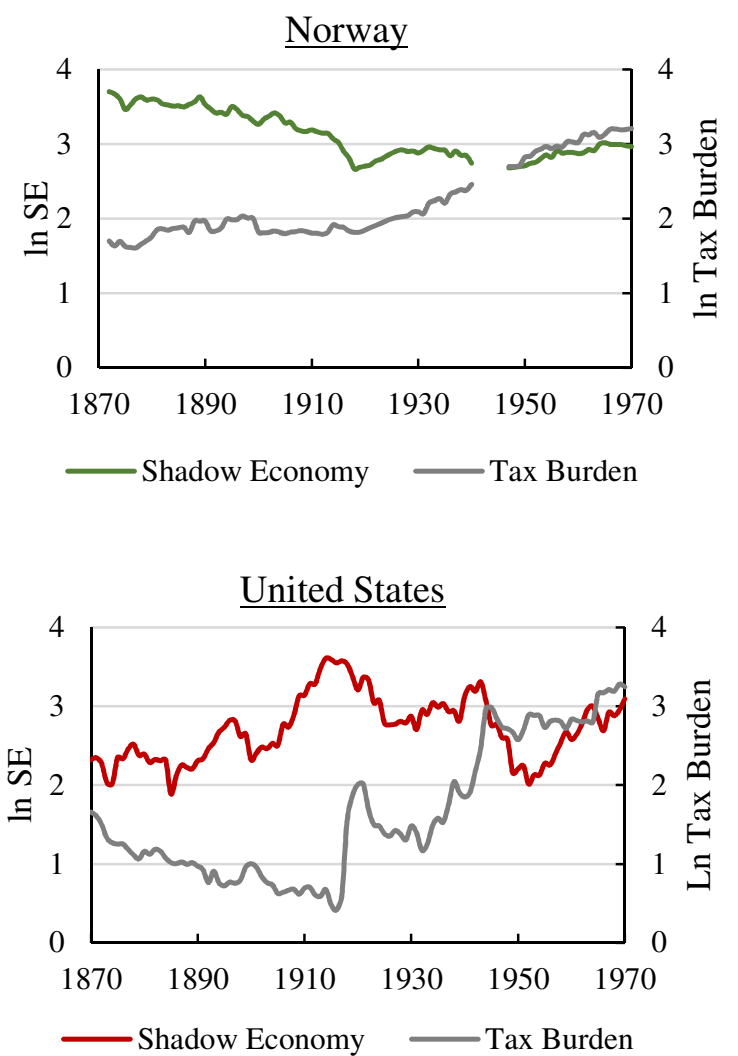
Figure E3 depicts the relationship between the shadow economy and the tax burden during the 19702015 period. The variations in the tax burden are less pronounced however during periods when the burden of taxation increases shadow economic also increases soon after, implying a positive correlation between the two variables. The exception is Sweden where there seems to be a negative relationship.

\section{Figure E3: Shadow Economies and the Tax Burden 1970-2015}
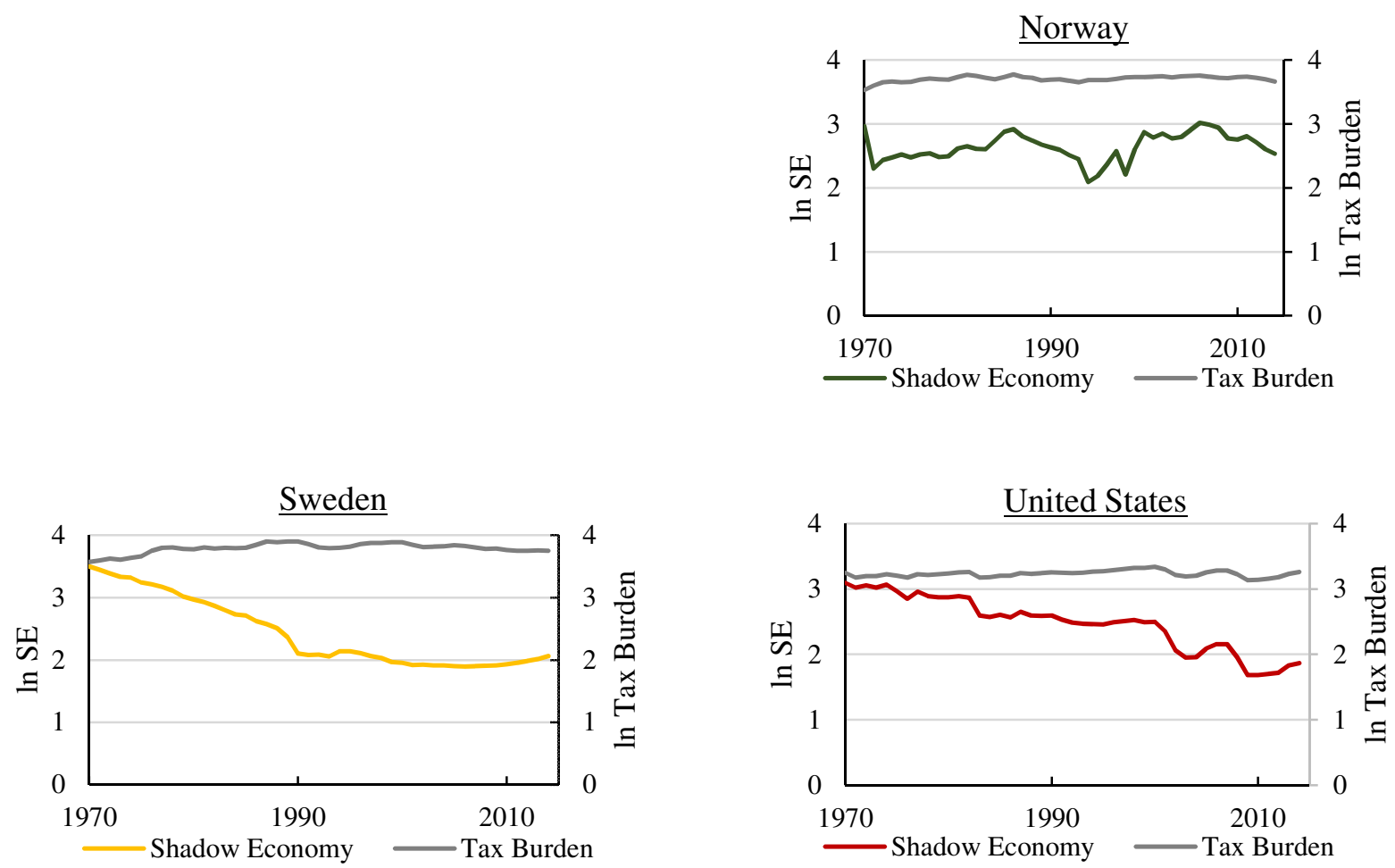

Figure E4 graphs the relationship between the rate of unemployment and the size of the shadow economy. Unemployment is hypothesised to have a positive effect on the size of the shadow economy. In the United Kingdom, Sweden and the United States there apprears to be a positive correlation between the two variables; an increase in unemployment leads to an increase in shadow annnnmin nntiviter and vice versa. It is difficult to infer a relationship fin the case of Norway due to
Source: Own Calculations gaps in the data. 

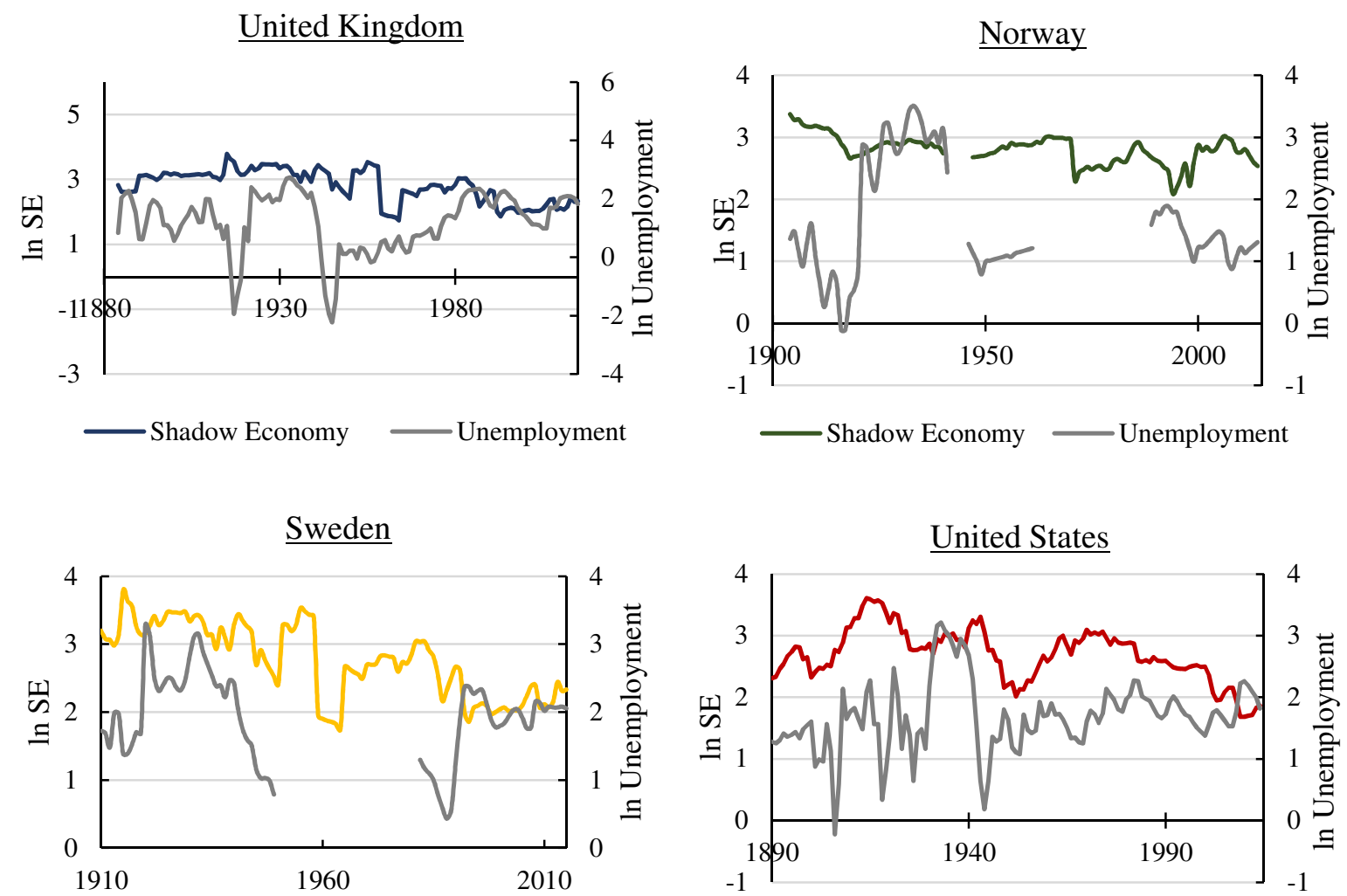

Source: Own Calculations

Unemployment

- Shadow Economy Unemployment 